PNL-7341

UC-903

Evaluations of the Effects of the Columbia River on the Unconfined Aquifer Beneath the 1301-N Liquid Waste Disposal Facility
T. J. Gilmore
J. P. McDonald
J. V. Borghese
D. R. Newcomer

May 1990

Prepared for the U.S. Department of Energy under Contract DE-AC06-76RLO 1830

Pacific Northwest Laboratory Operated for the U.S. Department of Energy by Battelle Memorial Institute 


\title{
DISCLAIMER
}

This report was prepared as an account of work sponsored by an agency of the United States Government. Neither the United States Government nor any agency thereof, nor Battelle Memorial Institute, nor any of their employees, makes any warranty, expressed or implied, or assumes any legal liability or responsibility for the accuracy, completeness, or usefulness of any information, apparatus, product, or process disclosed, or represents that its use would not infringe privately owned rights. Reference herein to any specific commercial product, process, or service by trade name, trademark, manufacturer, or otherwise, does not necessarily constitute or imply its endorsement, recommendation, or favoring by the United States Government of any agency thereof, or Battelle Memorial institute. The views and opinions of authors expressed herein do not necessarily state or reflect those of the United States Government or any agency thereof.

\author{
PACIFIC NORTHWEST LABORATORY \\ operated by \\ BATTELLE MEMORIAL INSTITUTE \\ for the \\ UNITED STATES DEPARTMENT OF ENERGY \\ under Contract DE-AC06-76RLO 1830
}

Printed in the United States of America

Available to DOE and DOE contractors from the

Office of Scientific and Technical Information, P.O. Box 62, Oak Ridge, IN 37831; prices available from (615) 576-8401. FTS 626-8401.

Available to the public from the National Technical Information Service, U.S. Department of Commerce, 5285 Port Royal Rd., Springfield, VA 22161.

NTIS Price Codes, Microfiche A01

Printed Copy

\begin{tabular}{cr}
\hline Price Code & Page Range \\
\hline A02 & $1-10$ \\
A03 & $11-50$ \\
A04 & $51-75$ \\
A05 & $76-100$ \\
A06 & $101-125$ \\
A07 & $126-150$ \\
A08 & $157-175$ \\
A09 & $176-200$ \\
A10 & $201-225$ \\
A11 & $226-250$ \\
A12 & $251-275$ \\
A13 & $276-300$ \\
A 14 & $301-325$
\end{tabular}

\begin{tabular}{cc}
\hline Price Code & Page Range \\
\hline A15 & $326-350$ \\
A16 & $351-375$ \\
A17 & $376-400$ \\
A18 & $401-425$ \\
A19 & $426-450$ \\
A20 & $451-475$ \\
A21 & $476-500$ \\
A22 & $501-525$ \\
A23 & $526-550$ \\
A24 & $551-575$ \\
A25 & $576-600$ \\
A99 & $601-4 p$
\end{tabular}


Evaluations of the Effects of the Columbia River on the Unconfined Aquifer Beneath the 1301-N Liquid Waste Disposal Facility
T. J. Gilmore
J. P. McDonald
J. V. Borghese
D. R. Newcomer

May 1990

Prepared for the U.S. Department of Energy under Contract DE-AC06-76RLO 1830

Pacific Northwest Laboratory

Operated for the U.S. Department of Energy by Battelle Memorial Institute 


\title{
DISCLAIMER
}

This report was prepared as an account of work sponsored by an agency of the United States Government. Neither the United States Government nor any agency thereof, nor Battelle Memorial Institute, nor any of their employees, makes any waranty, expressed or implied, or assumes any legal liability or responsibility for the accuracy, completeness, or usefulness of any information, apparatus, product, or process dlsclosed, or represents that its use would not infringe privately owned rights. Reference herein to any specific commercial product, process, or service by trade name, trademark, manufacturer, or otherwise, does not necessarily constitute or imply its endorsement, recommendation, or favoring by the United States Covernment of any agency thereof, or Battelle Memorial Institute. The views and opinions of authors expressed herein do not necessarily state or reflect those of the United States Government or any agency thereof.

\author{
PACIFIC NORTHWEST LABORATORY \\ operated by \\ BATTELLE MEMORIAL INSTITUTE \\ for the \\ UNITED STATES DEPARTMENT OF ENERGY \\ under Contract DE-AC06-76RLO 1830
}

Printed in the United States of America

Available to DOE and DOE contractors from the

Office of Scientific and Technical Information, P.O. Box 62, Oak Ridge, TN 37831; prices available from (615) 576-8401, FTS 626-8401.

Available to the public from the National Technical Information Service,

U.S. Department of Commerce, 5285 Port Royal Rd., Springfield, VA 22161.

NTIS Price Codes, Microfiche A01

Printed Copy

\begin{tabular}{cr}
\hline Price Code & Page Range \\
\hline A02 & $1-10$ \\
A03 & $11-50$ \\
A04 & $51-75$ \\
A05 & $76-100$ \\
A06 & $107-125$ \\
A07 & $126-150$ \\
A08 & $151-175$ \\
A09 & $176-200$ \\
A10 & $201-225$ \\
A11 & $226-250$ \\
A12 & $251-275$ \\
A13 & $276-300$ \\
A14 & $301-325$
\end{tabular}

\begin{tabular}{cc}
\hline Price Code & Page Range \\
\hline A15 & $326-350$ \\
A16 & $351-375$ \\
A17 & $376-400$ \\
A18 & $401-425$ \\
A19 & $426-450$ \\
A20 & $451-475$ \\
A21 & $476-500$ \\
A22 & $501-525$ \\
A23 & $526-550$ \\
A24 & $551-575$ \\
A25 & $576-600$ \\
A99 & $601-U p$
\end{tabular}




\section{EVALUATIONS OF THE EFFECTS OF THE COLUMBIA RIVER ON THE UNCONFINED AQUIFER BENEATH THE 1301-N LIQUID WASTE DISPOSAL FACILITY}
T. J Gilmore
J. V. Borghese
J. P. McDonald
D. R. Newcomer

May 1990

Prepared for the U.S. Department of Energy under Contract DE-AC06-76RL0 1830 


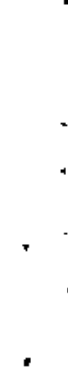




\section{EXECUTIVE SUMMARY}

The unconfined ground-water flow system beneath the 1301-N facility in the 100-N Area on the Hanford Site is affected by a number of factors including geologic facies changes, Columbia River stage fluctuations, and artificial recharge from adjacent waste-water disposal facilities. Watertable elevation data indicate that water levels beneath the 1301-N facility have declined approximately $2 \mathrm{ft}$ from October 1989 to February 1990. These data also indicate that a ground-water mound under the adjacent $1325-\mathrm{N}$ facility that existed prior to the "dry layup" status of the $N$ Reactor has largely dissipated. The current dominant water-table feature in the 100-N Area is the ground-water mound under the nearby 1324-N/NA ponds.

Statistical analysis of the water-level data indicate a strong correlation between river stage and the water-table fluctuations in wells located within $480 \mathrm{ft}$ of the river. Wells located between 860 and $2570 \mathrm{ft}$ from the river do not indicate significant association between water-level fluctuations and river stage elevation. The time $l a g$ between river stage changes and the corresponding effects in the wells located within $480 \mathrm{ft}$ of the river range from less than $1 \mathrm{~h}$ up to $15 \mathrm{~h}$. Attenuation of these responses ranges from 0.13 to 0.51 . Generally the time 1 ags and attenuation of response to the river-level fluctuations increase with distance from the river.

Impacts of river stage fluctuations on the ground-water system beneath the 1301-N facility were not evident during the period of study. Water leveis in the vicinity of the $1301-\mathrm{N}$ facility were predominantly influenced by the regional gradient and the ground-water mound beneath the 1324-N/NA facility. Other factors, such as barometric effects, do not have a significant influence on the water-table elevations. 


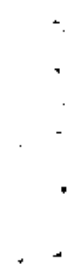




\section{CONTENTS}

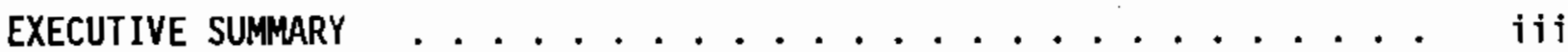

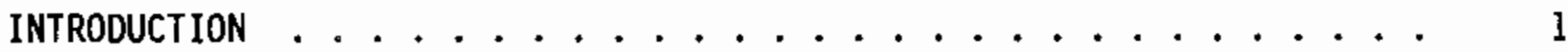

PREVIOUS WORK ..................... 1

BACKGROUND INFORMATION $\ldots \ldots \ldots \ldots$

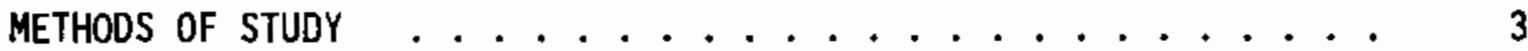

Water-Leve1 Monitoring Equipment . . . . . . . . . 6

Data Verification of Water-Level Recorders . . . . . . 8

Columbia River stage ................. 9

Problems Encountered . . . . . . . . . . . . 9

GEOLOGIC AND HYOROLOGIC SETTING ................ 11

RINGOLD FORMATION ........................ 11

GLACIOFLUVIAL SEDIMENTS . . . . . . . . . . . 12

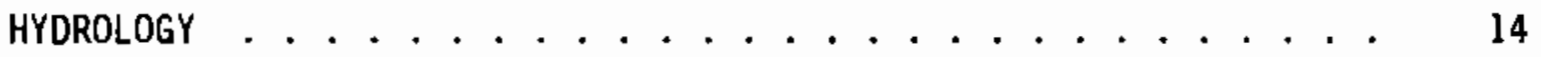

Ground Water .................. 14

Surface Water .............. 17

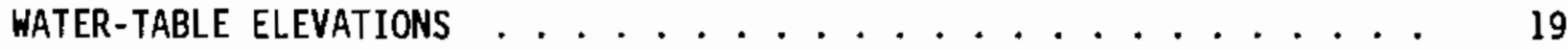

STATISTICAL ANALYSIS . . . . . . . . . . . . . . 25

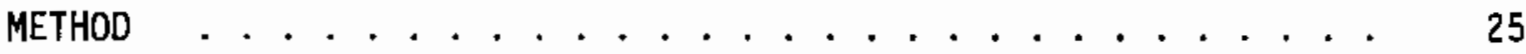

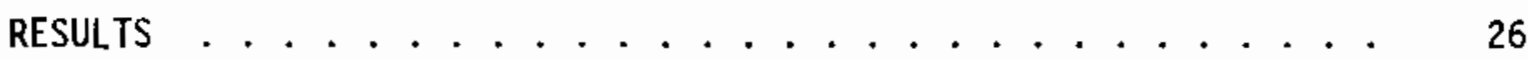

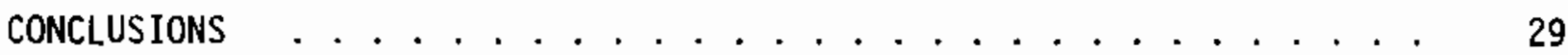

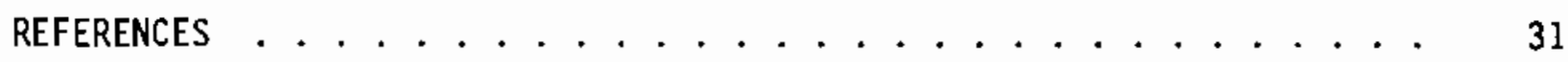

$\begin{aligned} \text { APPENDIX A } & \text { WATER-TABLE MAPS OF THE UNCONFINED AQUIFER } \\ & \text { BENEATH THE } 100-N \text { AREA .......... . . . . . . . . }\end{aligned}$

APPENDIX B - GRAPHS OF HOURLY COLUMBIA RIVER STAGE DATA
NEAR THE $100-\mathrm{N}$ AREA ........ B. . . . . . . . .

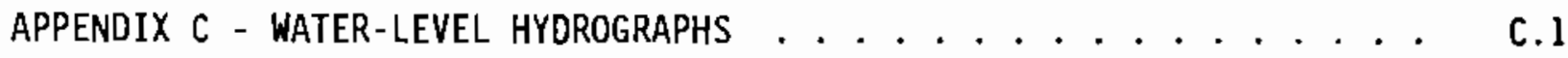




\section{FIGURES}

1 Map of the Hanford Site ............... 2

2 Locations of Monitoring Wells Near the 1301-N Liquid Waste Disposal Facility ................. 5

3 Water-Stage Recorder ................ 7

4 Location of Cross Section A-A' ............. 13

5 Generalized Cross Section A-A' Near the 1301-N Facility . . . . 15

6 Water-Leve] Elevations Showing the Ground-Water Mound Near the 1325-N Facility, May 30, 1989 ............. 20

7 Columbia River 5-Day Average Stage, October 1989February 1990 . . . . . . . . . . . . . . . 22

8 Hourly Water-Level Elevations Versus Hourly Barometric Pressure Data for Well 199-N-34 ............

\section{IABLES}

1 Waste-Water Discharges to 1324-N/NA Ponds: Elementary Neutralization Unit System Surge Tank Discharges . . . . . . . . . 4

2 Continuous Water-Level Monitoring Points .......... 4

3 Change in Water Levels and 100-N River Stage .......... 21

4 Results of Statistical Parameter Analysis Between the River Stage Fluctuations and the Well Water-Level Fluctuations for January 10 Through January $31,1989 \ldots . .$. . 


\section{INTRODUCTION}

Westinghouse Hanford Company (WHC) requested that Pacific Northwest Laboratory (PNL) perform a study to determine what influence the Columbia River has on the aquifer beneath the 1301-N Liquid Waste Disposal Facility (LWDF) 1ocated in the 100-N Area. Because of the change in operational status of the N Reactor to "dry layup" in November 1989, there has been a reduction in the liquid effluent discharge to the ground in the 100-N Area. This reduction in discharge reduces the artificial recharge to the unconfined aquifer, thereby altering ground-water flow in the vicinity of the 1301-N LWDF.

This study addresses these changes and evaluates the effect that the Columbia River has on the unconfined aquifer beneath the 1301-N facility under present ground-water conditions. In addition, information developed by this study will be utilized by the Environmental Division of WHC in their concurrent study entitled "Numerical Simulation of Radionuclide Transport from the 1301-N and 1325-N LWDFs to the Columbia River."

\section{PREVIOUS WORK}

Reports on the ground water and its interaction with the disposal facilities at the 100-N Area include Jensen (1987) and Nelson (1964). Newcomer (1988) addresses the effects of bank storage with Columbia River fluctuations. Reports on the hydrogeology have also been included in published reports on two Resource Conservation and Recovery Act (RCRA) ground-water monitoring programs in the 100-N Area including Gilmore (1989) and Gilmore and Jensen (1989), which outline ground-water quality assessment programs at the 1301-N and 1324-N/NA facilities. Quarterly and annual RCRA monitoring program status reports (PNL 1988a, 1988b, 1988c, and 1988d; Fruland et a1. 1989a, 1989b; and

Smith et a1. 1989a, 1989b) included ground-water surface elevation maps of the 100-N Area for each month between January 1988 and February 1990.

\section{BACKGROUND INFORMATION}

The study area is 1ocated on the U.S. Department of Energy's (DOE) Hanford Site in southeastern Washington State (Figure 1). The study location encompasses an area within the 100-N Area, in the vicinity of the 1301-N LWDF. 


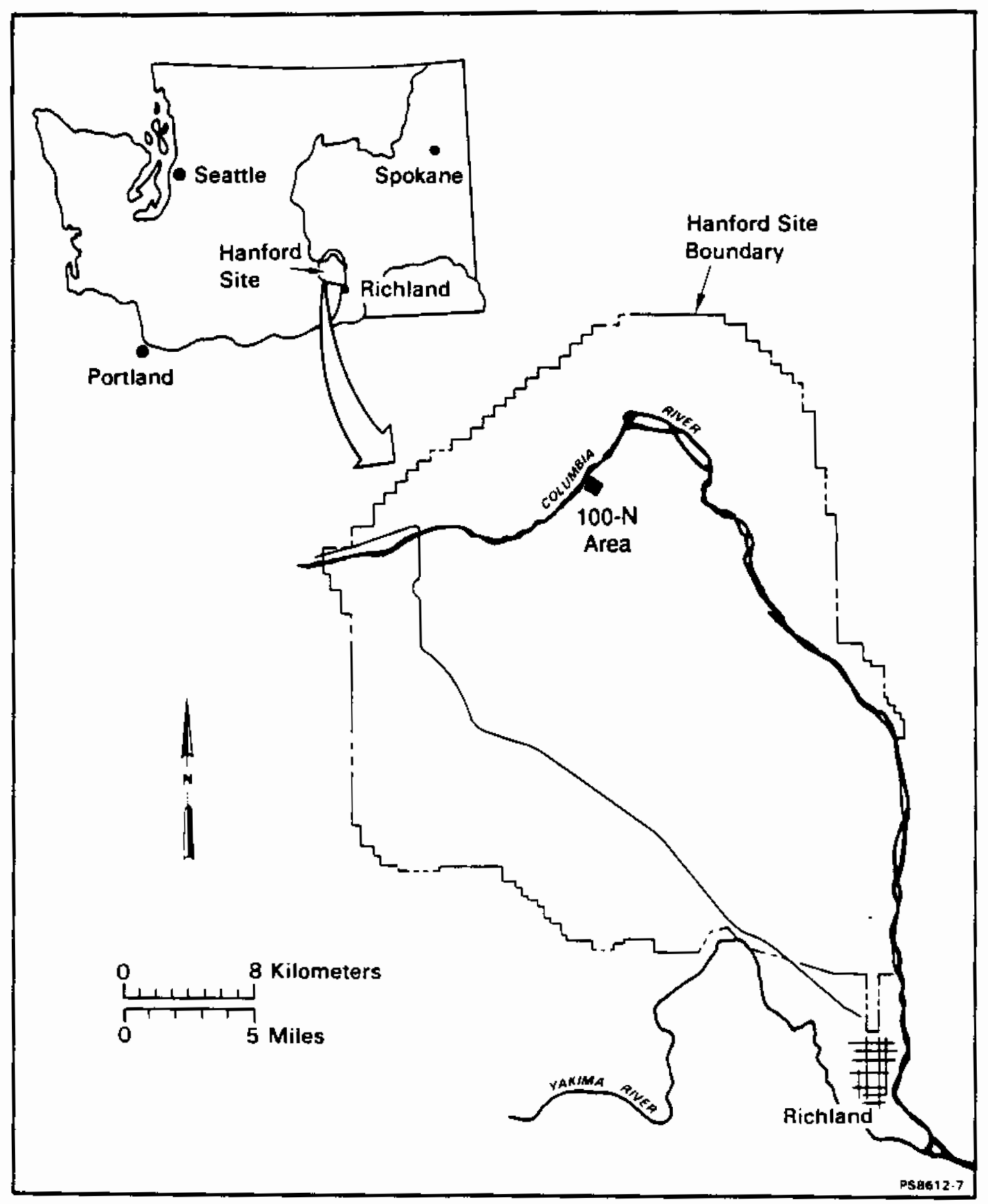

FIGURE_ _. Map of the Hanford Site 
The 1301-N LWDF was used to dispose of waste streams that were generated in the $\mathrm{N}$ Reactor and related facilities, from the startup of the $\mathrm{N}$ Reactor in 1963 until September 1985. The $1301-\mathrm{N}$ facility is currently not in use. The $1301-N$ LWDF is located approximately $800 \mathrm{ft}$ east of the Columbia River. It consists of a $52-$ by $12-\mathrm{ft}$ concrete- 1 ined ditch connected to a $125-$ by $250-\mathrm{ft}$ unlined rectangular basin. The basin bottom is covered with a 3-ft-thick layer of large stones. Adjacent to the basin is an unlined ditch $1600 \mathrm{ft}$ long, $50 \mathrm{ft}$ wide, and $12 \mathrm{ft}$ deep, which extends north in a zigzag pattern. The ditch was intended to handle overflow from the basin. Two other facilities of importance to this report are the 1325-N Liquid Waste Disposal Facility (LWDF) and the 1324-N/NA ponds. These facilities have received liquid effluent in the past, and continued to receive reduced volumes of effluent during the course of this study. The amount of discharge to these two facilities has been greatly reduced following the operational status change for the N Reactor in April 1989. The 1325-N LWDF, during the course of this study, received a continuous stream of approximately $300 \mathrm{gal} / \mathrm{min}$. The discharges to the 1324-N/NA Ponds are listed in Table 1.

\section{METHODS OF STUDY}

Continuous water-level measurements were collected from 12 wells in the vicinity of the 1301-N LWDF between the end of October 1989 and the beginning of April 1990. The 12 wells monitored are listed in Table 2 and their locations are shown in Figure 2. Water-table maps constructed from these data are located in Appendix $A$. The continuous water-level monitoring points were located in wells on a line generally parallel to and between the river and the $1301-N$ facility and on a line that runs through the facility approximately perpendicular to the river. Additional monitoring points were located adjacent to the 1325-N and 1324-N/NA facilities to assess their effect on the ground-water surface elevations. In addition, Columbia River stage data were also obtained from the Hanford Generating Project located approximately $2500 \mathrm{ft}$ upstream of the 1301-N Crib area. Graphs of the Columbia River stage data are presented in Appendix $B$.

Water-level data were gathered using three types of continuous waterleve1 monitoring equipment: chart-type stage recorders, stage recorders with 
TABLE 1. Waste-Water Discharges to 1324-N/NA Ponds: Elementary Neutralization Unit System Surge Tank Discharges

\begin{tabular}{|c|c|c|c|}
\hline Date & Gallons & Date & Gallons \\
\hline $12 / 25 / 89$ & 177,000 & $1 / 27 / 90$ & 175,000 \\
\hline $12 / 28 / 89$ & 175,000 & $1 / 30 / 90$ & 188,000 \\
\hline $12 / 31 / 89$ & 238,000 & $1 / 31 / 90$ & 140,000 \\
\hline $1 / 02 / 90$ & 151,000 & $1 / 03 / 90$ & 158,000 \\
\hline $1 / 04 / 90$ & 130,000 & $2 / 04 / 90$ & 175,000 \\
\hline $1 / 08 / 90$ & 216,000 & $1 / 08 / 90$ & 193,000 \\
\hline $1 / 10 / 90$ & 166,000 & $2 / 11 / 90$ & 182,000 \\
\hline $1 / 14 / 90$ & 170,000 & $2 / 14 / 90$ & 179,000 \\
\hline $1 / 16 / 90$ & 166,000 & $2 / 19 / 90$ & 195,000 \\
\hline $1 / 19 / 90$ & 149,000 & $2 / 20 / 90$ & 216,000 \\
\hline $1 / 23 / 90$ & 136,000 & $2 / 22 / 90$ & 254,000 \\
\hline Subtotals: & $1,874,000$ & Subtotal: & $2,055,000$ \\
\hline & $3,929,000$ gallons & Days: & \\
\hline & & & \\
\hline
\end{tabular}

TABLE 2. Continuous Water-Level Monitoring Points

\begin{tabular}{|c|c|c|c|}
\hline Well & $\begin{array}{c}\text { Recorder } \\
\text { Type } \\
\end{array}$ & $\begin{array}{l}\text { Data Collection } \\
\text { Frequency, min }\end{array}$ & Dates in Service \\
\hline $\begin{array}{l}N-3 \\
N-85 \\
N-8 P \\
N-20 \\
N-23 \\
N-25 \\
N-27 \\
N-34 \\
N-51 \\
N-58 \\
N-66 \\
N-67\end{array}$ & $\begin{array}{l}\text { SR } \\
\text { LPT } \\
\text { LPT } \\
\text { SRL } \\
\text { SRL } \\
\text { SR } \\
\text { SR } \\
\text { SR } \\
\text { SR } \\
\text { LPT } \\
\text { LPT } \\
\text { LPT }\end{array}$ & $\begin{array}{l}60 \\
30 \\
30 \\
30 \\
30 \\
60 \\
60 \\
60 \\
60 \\
30 \\
30 \\
30\end{array}$ & $\begin{array}{r}2 / 21 / 90-3 / 31 / 90 \\
1 / 10 / 90-3 / 31 / 90 \\
1 / 10 / 90-3 / 31 / 90 \\
12 / 28 / 89-3 / 31 / 90 \\
12 / 20 / 89-3 / 31 / 90 \\
12 / 20 / 89-3 / 31 / 90 \\
10 / 25 / 89-3 / 31 / 90 \\
12 / 20 / 89-3 / 31 / 90 \\
12 / 05 / 89-3 / 31 / 90 \\
12 / 22 / 89-3 / 31 / 90 \\
2 / 04 / 90-3 / 31 / 90 \\
10 / 19 / 89-3 / 31 / 90\end{array}$ \\
\hline
\end{tabular}




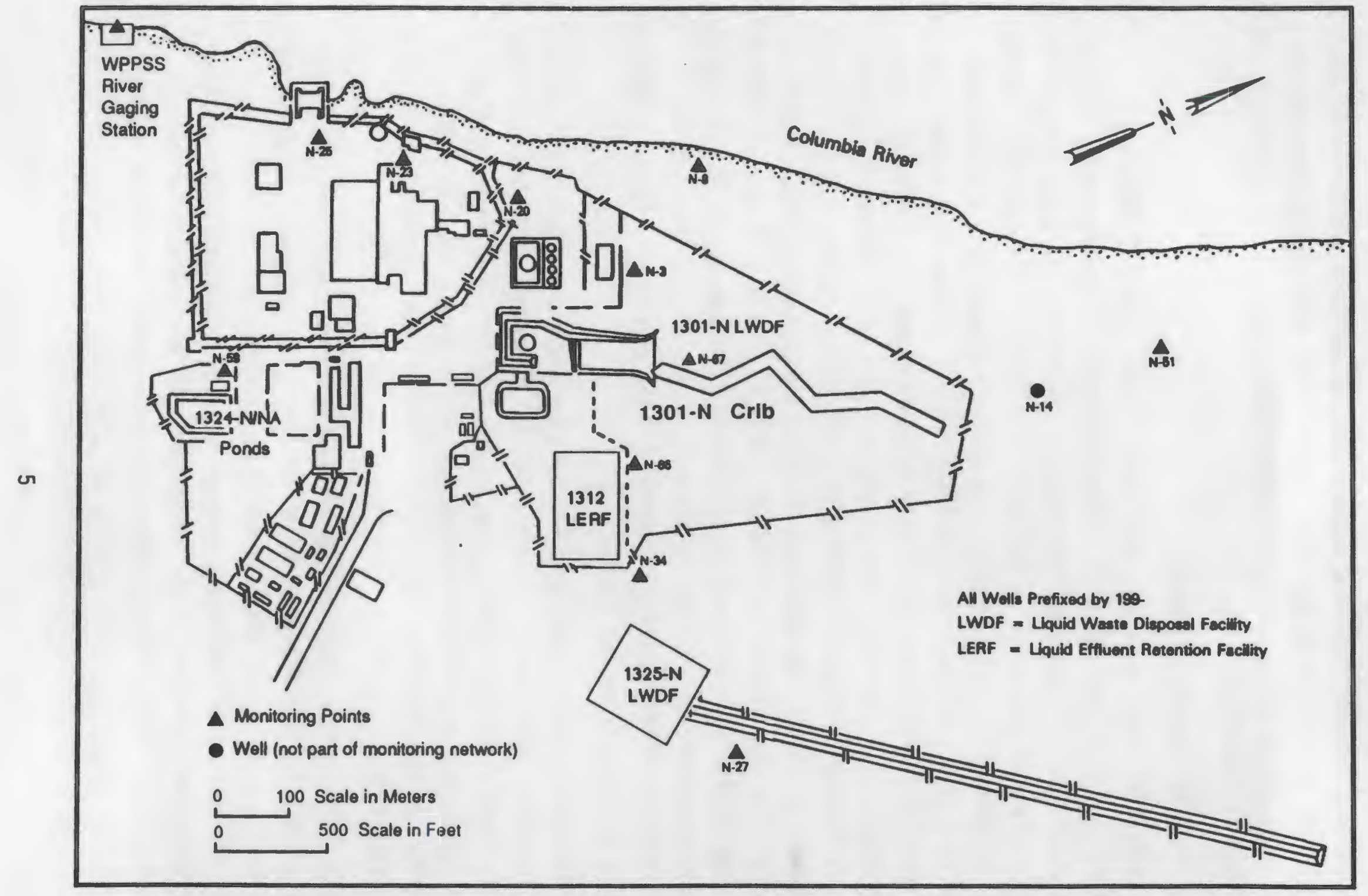

FIGURE 2. Locations of Monitoring Wells Near the 1301-N Liquid Waste Disposal Facility 
attached data loggers, and data loggers with bridge-type pressure transducers. To calibrate the recording equipment, water-level measurements were periodically taken at the well sites using steel tapes. Water-level hydrographs are presented in Appendix C.

\section{Water-Leve] Monitoring Equipment}

Mechanical stage recorders were used in wells 199-N-3, 199-N-25, 199-N-27, 199-N-34, and 199-N-51. These mechanical stage recorders continuously monitor water levels by recording the position of a float, which floats on the surface of the water in the well. The float is attached to a counterweight by means of a beaded cable. The cable is placed over a pulley connected to a drum, the face of which holds a chart (Figure 3). A pen is driven at a constant speed across the drum by either a manual or electronic timer. As the float rises and falls in response to water-level changes in the well, the drum turns proportionally producing a chart that records the water level in relation to time. The charts produced by the mechanical stage recorders were digitized for computer processing. The stage recorders in wells $199-\mathrm{N}-20$ and 199-N-23 were equipped with an electronic data logger. An optical encoder is used to convert the rotation of the pulley into digital information, which is recorded at discrete periodic intervals. The electronic loggers eliminated the need for digitizing the chart.

These water-level stage recorders were reliable and accurate devices for recording water-level data. Their simple design results in instruments that are relatively free of problems. The accuracy of this equipment is affected by the clock accuracy, freedom of movement of the float, the ratio between water-level change and drum rotation, and thermal expansion/contraction of the float line, (considered to be negligible).

Electronic data loggers and bridge-type pressure transducers were used in wells 199-N-8s, 199-N-8p, 199-N-58, 199-N-66, and 199-N-67. These transducers employ a diaphragm that deforms under pressure and correspondingly affects the electrical resistance through a group of resistors (Wheatstone bridge) attached or linked to the diaphragm. The corresponding change in resistance across the bridge is converted to the change in feet of water. 


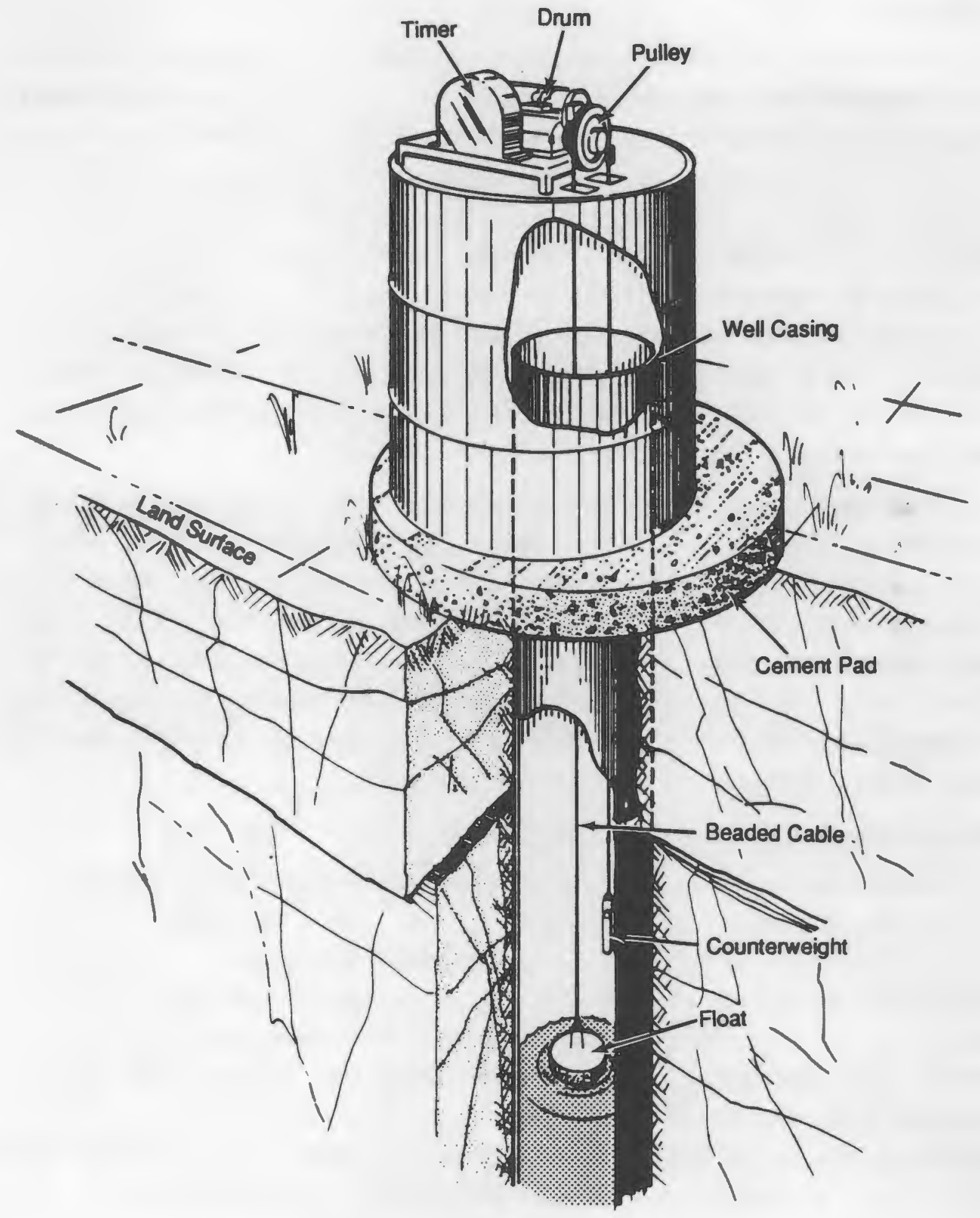

FIGURE 3. Water-Stage Recorder (Modified after Jensen 1987) 
This reading is then stored along with the time of the measurement in the data logger's Random Access Memory (RAM) for later downloading to a computer for processing.

The accuracy of pressure transducer measurements is affected by the specific design of the transducer and data logger, the response of the equipment to environmental conditions and the stability of the transducer's position in the well. The data loggers used were designed with either a 10- or 12-bit processing capacity. The 12-bit machines used on this study were capable of providing a resolution of $0.01 \mathrm{ft}$; however, the 10-bit machine used in well 199-N-67 rounded its data for a resolution of $0.035 \mathrm{ft}$. When possible, the transducers were installed $24 \mathrm{~h}$ or more before the start of data collection. This allowed the equipment to equilibrate to environmental conditions and for the cable to stretch to an equilibrium point, thus stabilizing the transducer at a specific depth.

The logger clocks and recorder timers used in this study were standardized with a field watch set to $8 \mathrm{hr}$ behind Coordinated Universal Time (from radio station WWV, Colorado) yielding Pacific Standard Time (PST) and is traceable to the National Institute of Standards and Technology (NIST). The chart data were digitized for computer processing using the value at the "top of each hour." This yielded data frequency of every $60 \mathrm{~min}$. The loggers were programmed for data collection frequency of $30 \mathrm{~min}$ and set to record their measurements simultaneously at each half-hour mark.

\section{Data Verification of Water-Level Recorders}

Water-level measurements using steel tapes were taken at the beginning of each data collection period to calibrate the loggers to a known level and to index the charts with respect to time on the stage recorders. Calibration measurements were also taken periodically during data collection periods to correct for drift of the recording equipment. When steel-tape measurements did not correspond to the instrument's recording, the instrument was reset. The tapes used in this study were compared to a standard tape that is calibrated annually by the Westinghouse Standards Laboratory, and traceable to the NIST. The steel-tape measurements are indicated on the hydrographs in Appendix C. 


\section{Columbia River Stage}

Stage data for the Columbia River are recorded by the Hanford Generating Project, which is operated by the Washington Public Power Supply System (WPPSS). These measurements are taken at a point approximately $2500 \mathrm{ft}$ upstream of the 1301-N Crib area (Figure 2). The data are collected with an air bubbler system and are continuously recorded on a strip chart. Copies of these data were obtained and digitized for computer processing.

\section{Problems Encountered}

The overall quality of the data set is good with a few exceptions. Complete and/or verified data sets from wells $199-\mathrm{N}-67$ and $199-\mathrm{N}-3$ were unobtainable. A logger/transducer had been installed in well 199-N-67 in the middle of October 1989. These two wells are inside a radiation zone surrounding 1301-N Crib area. At the end of October, new procedures for working in radiation zones were implemented that denied field personnel access to these two wells. As a result of implementing the new procedures, field personnel received additional training so they could service the equipment. The recorder in 199-N-67 had to be left unattended for a period of 4 months. During this time, the equipment experienced an instrument drift problem. When the data were collected in February, the transducer readings were $0.78 \mathrm{ft}$ lower than the actual water level. The data logger in well 199-N-67 later failed for an unknown reason, resulting in a loss of data between early February and April. The data set for well $199-\mathrm{N}-3$ is incomplete, missing October through February 17, also as a result of the access requirements into the radiation zone.

The logger/transducer installed at well 199-N-8P experienced an instrument shift. In this case, the error seems to have occurred suddenly. The transducer readings corresponded well with the steel-tape measurements, then were higher by approximately $0.21 \mathrm{ft}$ beginning in early february. The logger was reset when the problem was discovered.

of the six chart recorders used on this study, five were driven by electronic timers and one was driven by a manual timer. The electronic timers proved accurate; however, the manual timer was siow by $1 / 2$ to $1 \mathrm{hr}$ per week toward the end of the study. This recorder was installed at well 199-N-27, 
which did not produce rapid or large water-level changes, thus the timer. inaccuracy did not affect the interpretation of the data.

In wells $199-\mathrm{N}-25,199-\mathrm{N}-34,199-\mathrm{N}-27$ and $199-\mathrm{N}-3$, the recorder floats occasionally encountered obstructions, such as pump columns and wiring, as they responded to water-level changes. This resulted in chart data that "jumped" rather than recording in a smooth curve. At wells 199-N-25, 199-N-34, and 199-N-27, the maximum jump in data was $0.13 \mathrm{ft}$ as a result of float obstruction. Water-level data from well $199-\mathrm{N}-3$ were affected to a greater degree. The maximum shift was $0.30 \mathrm{ft}$ and one period of 6 days occurred when the float did not move at all.

Loss of data occurred at some of the well sites because of hydrochemical sampling activities. Three of the stage recorders were disturbed by sampling personnel, resulting in a loss of data of several hours at wells $199-\mathrm{N}-20$, 199-N-23, and 199-N-27. At well 199-N-25, a sample bailer was stuck downhole, resulting in a loss of data from February 6 through 16. 


\section{GEOLOGIC AND HYDROLOGIC SETTING}

There are approximately 70 wells that have been drilled in the $100-\mathrm{N}$ Area since 1962. Many of these wells provide the basis for the geologic interpretation for this report. The sample descriptions from the majority of these wells have been logged by drillers and do not have the detail or the consistency from which to draw more than generalized interpretations. The newer wells drilled under the RCRA programs have been logged by geologists and yield more detailed descriptions. In addition to these newer wells, there are natural gamma logs for many of the wells that can be used collectively with the sample descriptions to determine lithologies in the older wells.

The stratigraphy of the suprabasalt sediments in the 100-N Area and around the 1301-N LWDF include the Ringold Formation and the overlying glaciofluvial sediments informally referred to as the Hanford formation.

\section{RINGDLD FORMATION}

The Ringold Formation has been variously divided into the basal, lower, middle, and upper units based on sediment texture in the central portion of the Hanford Site (Brown 1959; Tallman et al. 1979; Routson and Fecht 1979; and Bjornstad 1984, 1985). These designations, however, may not be correlative to the sediments in the 100-N Area; therefore, the sediment descriptions in this report will be in general lithologic terms.

The Ringold Formation in the $100-\mathrm{N}$ Area is composed of three distinct lithologic units that include, in ascending order, an indurated sandy gravel unit, a mud unit, and a sandy gravel unit. The indurated sandy gravel unit rests unconformably on basalt at approximately $520 \mathrm{ft}$ below land surface (bls) (-78 ft below sea level). This indurated sandy gravel unit is approximately $35 \mathrm{ft}$ thick and is overlain by a caliche layer. The indurated sandy gravel unit was penetrated by the now abandoned we11, 699-86-60, under the 1312 Liquid Effluent Retention Facility (LERF). Overlying the indurated sandy gravel unit is a mud unit that extends to approximately $100 \mathrm{ft}$ bls ( $360 \mathrm{ft}$ above sea level). This unit is predominantly an olive brown color and composed of $75 \%$ mud (undifferentiated silts and clays) with $10 \%$ fine sands and $15 \%$ gravel. It appears from the logs that these lithologic fractions occur as 
a mixture rather than discrete horizons. It is generally recognized that the top of this mud unit forms the base of the unconfined aquifer.

Near the 1301-N LWDF, the contact of the Ringold Formation and the overlying glaciofluvial sediments occurs at approximately $60 \mathrm{ft}$ bls (410 ft above sea level). The Ringold is differentiated from the glaciofluvial sediments by an increase in calcium carbonate with a zone of increased consolidation and cementing, a decrease in the percentages of basalt clasts, and an increase in the quartz/silica-rich materials. These changes are reflected in a distinct color change from the olive gray of the glaciofluvial sediments to a dark grayish brown of the Ringold. This sandy gravel unit of the Ringold is heterogenous, varying in texture both laterally and vertically.

\section{GLACIOFLUVIAL SEDIMENTS}

Overlying the Ringold Formation are flood deposits that were deposited when ice-dammed lakes within the Columbia River drainage were periodically breached during Pleistocene glaciation (Bretz 1959; Baker 1973; Waitt 1980). Deposits of glaciofluvial sediments from these floods have been informally referred to as the Hanford formation. These deposits are highly variable both laterally and vertically, reflecting the dynamic nature of deposition. These cataclysmic flood deposits have been divided into two facies: a coarsegrained channel facies (the pasco gravels) and a fine-grained slackwater facies (the touchet beds) (DOE 1988). The pasco gravels predominate at the 100-N Area. These gravels are composed of poorly sorted coarse sand and gravel that were deposited in flood bars along high-energy flood channels (DOE 1988).

Near the 1301-N LWDF the upper $15 \mathrm{ft}$ of the sediments contain 5 to $20 \%$ cobbles and boulders in a generally coarse-grained matrix. From $15 \mathrm{ft}$ bls to the top of the Ringold Formation, the sediments are variable silty sandy gravel with an occasional boulder. The upper $55 \mathrm{ft}$ vary in texture laterally north of the facility to a coarser grained facies with decreasing finegrained sediments near well 199-N-51.

A generalized cross section (location shown in Figure 4) constructed from drillers' and geologists' logs indicates a lithology or facies change 


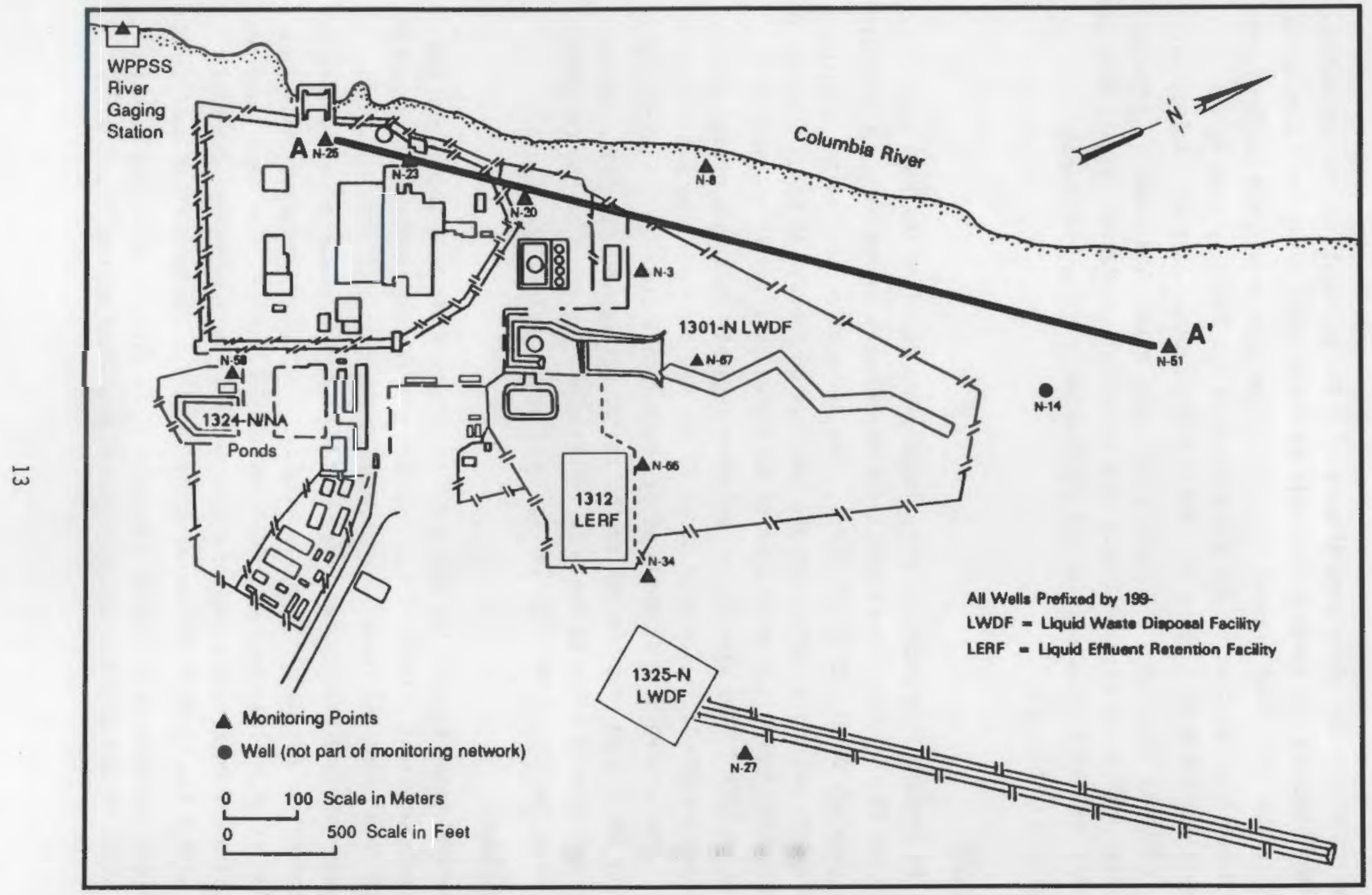

FIGURE 4. Location of Cross Section A-A' 
occurring within the study area (Figure 5). The sediments in the saturated zone that include the sandy gravel unit in the Ringold Formation increase in silts, clays, and finer grained material in the area around and south of the 1301-N facility relative to the areas north of the facility near wells 199-N-14 and 199-N-51 (Figure 2). (This cross section does not include wells that penetrate lower than the sandy gravel unit within the Ringold Formation discussed earlier in this section.) The lithologic or facies changes that are inferred from this cross section can control in part the hydrological responses of this area.

\section{HYDROLOGY}

The Hanford Site occupies approximately one-third of the land area within the Pasco Basin. The Pasco Basin encompasses approximately 1.2 million acres (Gephart et al. 1979; DOE 1988). The climate for the region is characterized by semi-arid conditions and receives on average of about $6.25 \mathrm{in}$. of precipitation annually. While most of this precipitation is evaporated or transpired back to the atmosphere, evidence suggests that some ground-water recharge from precipitation does occur at the Hanford Site (Gee and Heller 1985). The Hanford Site is bordered by the Columbia River to the north and east, by the Yakima River to the south, and by Rattlesnake Mountain, Yakima Ridge, and Umtanum Ridge to the west. Flow along the reach of the Columbia River near the 1301-N facility is regulated by the Priest Rapids Dam.

\section{Ground Water}

Ground water beneath the Hanford Site occurs under both unconfined and confined conditions. The confined aquifers beneath the Hanford Site have been divided into upper and lower flow systems (Gephart et al. 1979; DOE 1988). The upper confined flow system includes the interflow contacts and sedimentary interbed within the Saddle Mountain Basalts. Partially confining conditions may also exist in the lower Ringold Formation (DOE 1988). The lower confined flow system is contained within the flow contacts or brecciated interflow zones within the Wanapum and Grande Ronde Basalts. The unconfined aquifer is of primary interest in this report because it is directly affected by the river stage of the Columbia and by disposal practices at the Liquid Waste 
A

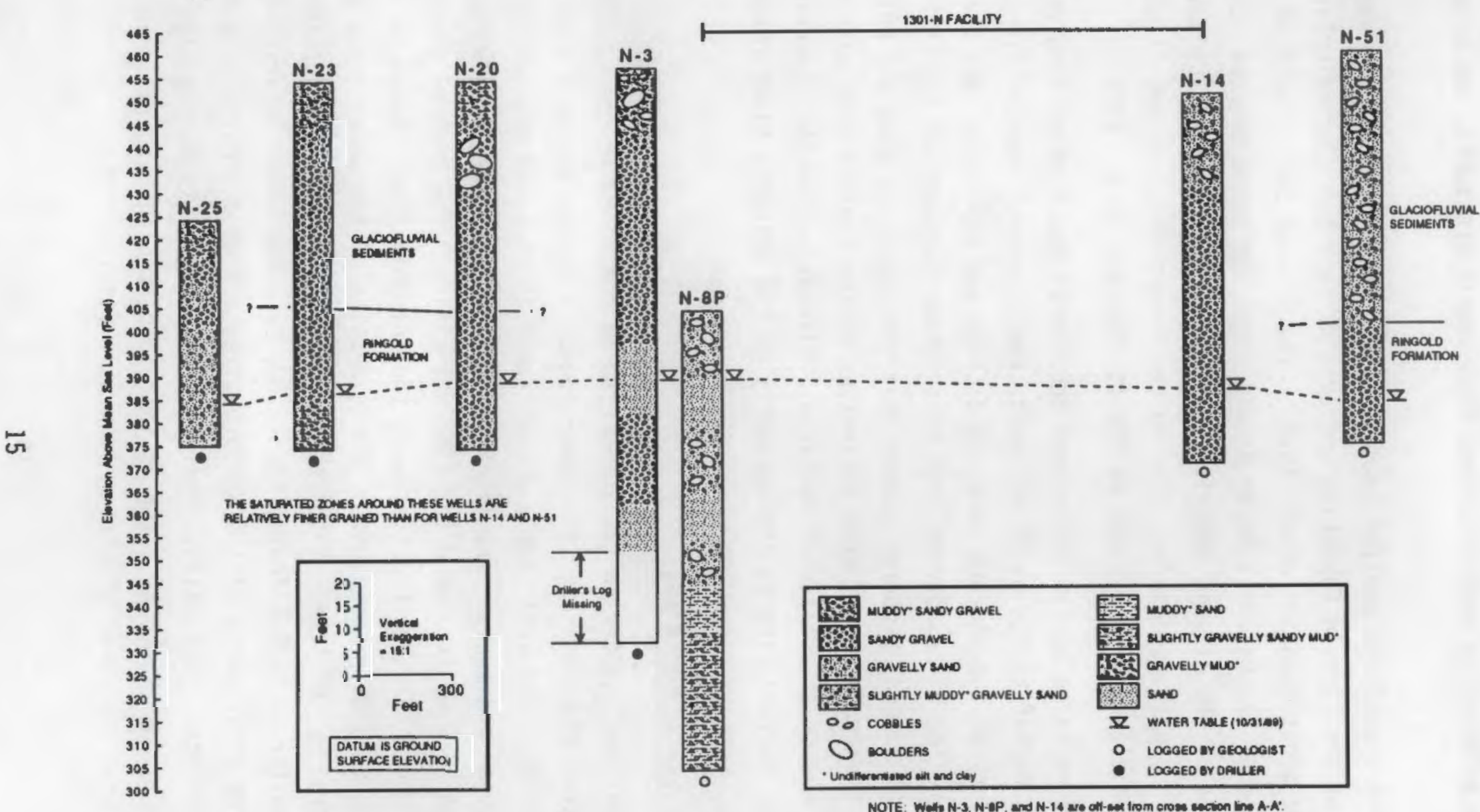

FIGURE 5. Generalized Cross Section A-A' Near the 1301-N Facility 
Disposal Facilities. To a lesser extent, water levels in the unconfined aquifer are also affected by precipitation, atmospheric pressures, and planetary effects.

A shallow unconfined aquifer is contained primarily within the sandy gravel unit of the Ringold Formation and extends into the glaciofluvial sediments in some areas (Gephart et a1. 1979). The base of the unconfined aquifer is the surface of the Columbia River Basalt Group, or where present, the clay/mud zones of the Ringold deposits. The saturated thickness of the unconfined aquifer beneath the Hanford Site ranges from zero along the flanks of the basalt anticlines to a maximum of $200 \mathrm{ft}$ (Gephart et a1. 1979).

Areas of recharge to the unconfined aquifer at the Hanford Site include areas of high relief to the north and west, two ephemeral streams along the western boundary of the Hanford Site, Cold Creek and Dry Creek, and the Columbia and Yakima Rivers during high river stage (Gephart et a1. 1979). A small amount of natural recharge occurs from precipitation (Gee and Heller 1985). Liquid waste disposal from activities on the Hanford Site also have been a major source of artificial recharge. Discharge from the unconfined aquifer on the Hanford Site is predominantly to the Columbia River (Gephart et al. 1979).

\section{Ground Water at 100-N Area}

The unconfined aquifer in the 100-N Area is contained in the sand/grave 1 unit of the Ringold Formation. Its lower boundary is the mud unit within the Ringold Formation. The water-table occurs about $20 \mathrm{ft}$ below the contact with the glaciofluvial sediments. The thickness of the unconfined aquifer in the $100-\mathrm{N}$ Area averages $65 \mathrm{ft}$ around the $1301-\mathrm{N}$ facility. The general groundwater flow direction is northwest, toward the Columbia River, based on interpretation of ground-water gradients. The elevation of the water table at the site is affected by the level of the nearby Columbia River, to which the unconfined aquifer is hydraulically connected, by groundwater entering the 100-N Area from other parts of the Hanford Site, and by discharge of waste water to the disposal facilities. Near the 1301-N facility during high river levels, bank storage along the river is increased, and in response groundwater levels near the river also rise (Newcomer 1988). 


\section{Surface Water}

The primary surface-water features associated with the Hanford Site are the Columbia and Yakima Rivers. Several surface ponds and ditches are present on site, and are generally associated with fuel and waste processing activities.

The average annual river flow along the Hanford reach of the Columbia, based on 65 years of record, is about $120,000 \mathrm{ft}^{3} / \mathrm{sec}$. Large-scale flooding of the Columbia River has occurred in the past, but the likelihood of such flooding recurring has been reduced by the construction of several flood control/water storage dams upstream from the Hanford Site. Normal Columbia River elevations within the site range from $394 \mathrm{ft}$ above mean sea level (MSL) at the northwestern boundary near Vernita, to $341 \mathrm{ft}$ at the southeastern boundary near the 300 Area.

The fluctuations of the river are regulated immediately upstream of the Hanford Site by the Priest Rapids Dam, which is a part of the Columbia Basin Water Project. The primary driving force in the utilization of the water supply for the Columbia Reservoir System is hydropower production (COE 1984). In addition to hydropower production, there are numerous other concerns of the Columbia Reservoir System that are ranked on a priority basis including flood control, municipal and industrial use, irrigation, fish and wildlife, and recreation use. Each year prior to June 30 , an operational utilization plan is developed for the following year, which controls the water releases and river levels in the system.

River-level fluctuations are reflective of a number of cyclical factors including daily, weekly, seasonal, and annual cycles. Daily cycles with river fluctuations of several feet are related to hydroelectric energy needs. Weekly cycles are also attributed to hydroelectric needs, these cycles show a decrease in river levels during weekend periods, which reflect a lower energy demand. Seasonal cycles, which are considered to have the greatest effect on the ground-water flow around the 1301-N facility, are influenced largely by the spring runoff, along with fish and wildlife management activities. In January and February, in preparation for the runoff, the reservoir system is lowered, creating higher river levels. In mid-April, there is another large 
release of water, which lasts over a month, to facilitate the salmon migration downstream. The largest release of water from the system occurs from May to the end of June, which represents the release of spring runoff (COE 1984). 


\section{WATER-TABLE ELEVATIONS}

Water levels in wells open to the unconfined aquifer beneath the 1301-N facility are influenced predominantly by river stage fluctuations and wastewater discharges to nearby facilities.

Water-table maps of the unconfined aquifer underlying the $100-\mathrm{N}$ Area show a decline in the water table beneath the 1301-N facility from October 31 , 1989, through January 25, 1990 (Appendix A). The amount of decline for this period is about $2 \mathrm{ft}$. Water levels measured with a steel tape from we11 199-N-67 confirm the areal decline shown on water-table maps. A measurement taken on October 19, 1989, was $391.11 \mathrm{ft}$ above MSL and a measurement taken on February 14, 1990, was $389.56 \mathrm{ft}$ above MSL, yielding a decline in water level of $1.55 \mathrm{ft}$.

Water-table maps constructed for the $100-\mathrm{N}$ Area indicate the influences of facilities on the ground-water system. A ground-water mound is present under the 1324-N/NA facility. The mound rose about $2 \mathrm{ft}$ in elevation from October to November 1989, as indicated by a water-level rise in well 199-N-61 located approximately $50 \mathrm{ft}$ east of the 1324-N/NA facility (Appendix A). A decline in the mound of about $4 \mathrm{ft}$ occurred during the period from November 1989 to January 1990 . The steepest gradient of the $1324-\mathrm{N} / \mathrm{NA}$ mound is northwest toward the Columbia River (Appendix A).

The 1325-N facility also had an influence on the water-table elevations in the 100-N Area. Prior to the waste-water discharge reduction to the 1325-N facility in about July 1989, a ground-water mound was present beneath the facility (Figure 6 ). This mound has dissipated since the reduction of waste-water flow from 1500-2000 gal/min. during operation of $\mathrm{N}$ Reactor to approximately $350 \mathrm{gal} / \mathrm{min}$. currently. Jensen (1987) noted that when the 1325$\mathrm{N}$ facility was not in operation, the ground-water mound beneath the facility dissipated outward in all directions. The maximum elevation of the water table beneath the 1325-N facility was approximately $413 \mathrm{ft}$ MSL in May 1989. The elevation of the water table beneath this facility in January 1990, was about $393 \mathrm{ft}$ MSL. The mound declined at an average rate of $0.08 \mathrm{ft} / \mathrm{day}$. The waste-water discharge to $1325-\mathrm{N}$, however, still appears to be influencing the water table beneath the facility based on the water-table maps. 


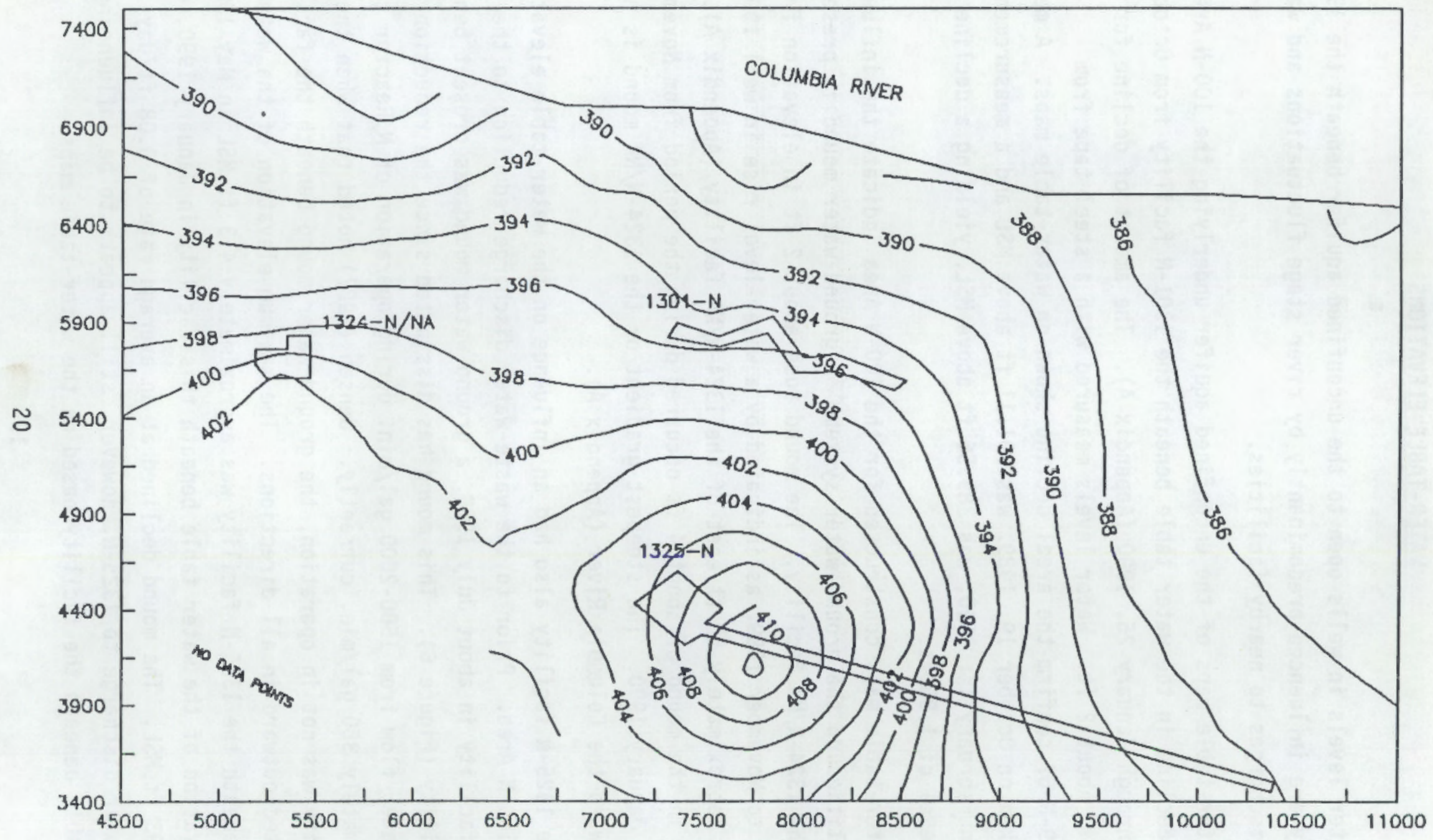

FIGURE 6. Water-Level Elevations Showing the Ground-Water Mound Near the 1325-N Facility, May 30, 1989 
The stage of the Columbia River regulated at the Priest Rapids Dam may fluctuate as much as 4 to $6 \mathrm{ft}$ daily (Appendix 8). A dampened daily change is seen in wel1s 199-N-8S, 199-N-8P, 199-N-20, 199-N-23, 199-N-25, and 199-N-51 (Appendix $C$ ). Table 3 shows the change in the water level in the wells responding to a decrease in river stage on January 21 , 1990 . We11 199-N-25 shows the greatest change.

The river stage generally increased from October 1989 through February 1990 (Figure 7). Water Tevels in wells 199-N-20, 199-N-23, 199-N-25, and 199-N-51 (Appendix $C$ ) also show an associated general increase. Wells 199-N-27, 199-N-34, 199-N-67, and 199-N-51, however, show a general decline in water level. Wel1s $199-\mathrm{N}-34$ and 199-N-58 show a decline in water level through January 1990. The declines in these wells may reflect the dissipation of the remnant ground-water mound under the $1325-\mathrm{N}$ facility.

The water-level in well 199-N-58 peaked in early February and waterlevel for well 199-N-34 peaked in mid-February. The shapes of the hydrographs for water-levels in these wells are similar; however, the peak in 199-N-34 is relatively dampened. These peaks in February may be in response to an increase in waste-water discharge to the 1324-N/NA ponds (see Table 1). Well 199-N-58 is located adjacent to the 1324-N/NA facility. Well 199-N-34 is

TABLE 3. Change in Water Levels and 100-N River Stage

Approximate Columbia River Stage Change, $\mathrm{ft}$ $-1.0$ Date $1 / 21 / 90$

\begin{tabular}{|c|c|c|}
\hline We11 Number & $\begin{array}{l}\text { Water Leve? } \\
\text { Change, ft }\end{array}$ & Date \\
\hline $\begin{array}{l}199-N-85 \\
199-N-8 P \\
199-N-20 \\
199-N-23 \\
199-N-25 \\
199-N-51\end{array}$ & $\begin{array}{l}-0.7 \\
-0.5 \\
-0.4 \\
-0.4 \\
-0.9 \\
-0.8\end{array}$ & $\begin{array}{l}1 / 21 / 90 \\
1 / 21 / 90 \\
1 / 21-22 / 90 \\
1 / 22 / 90 \\
1 / 21-22 / 90 \\
1 / 21 / 90\end{array}$ \\
\hline
\end{tabular}




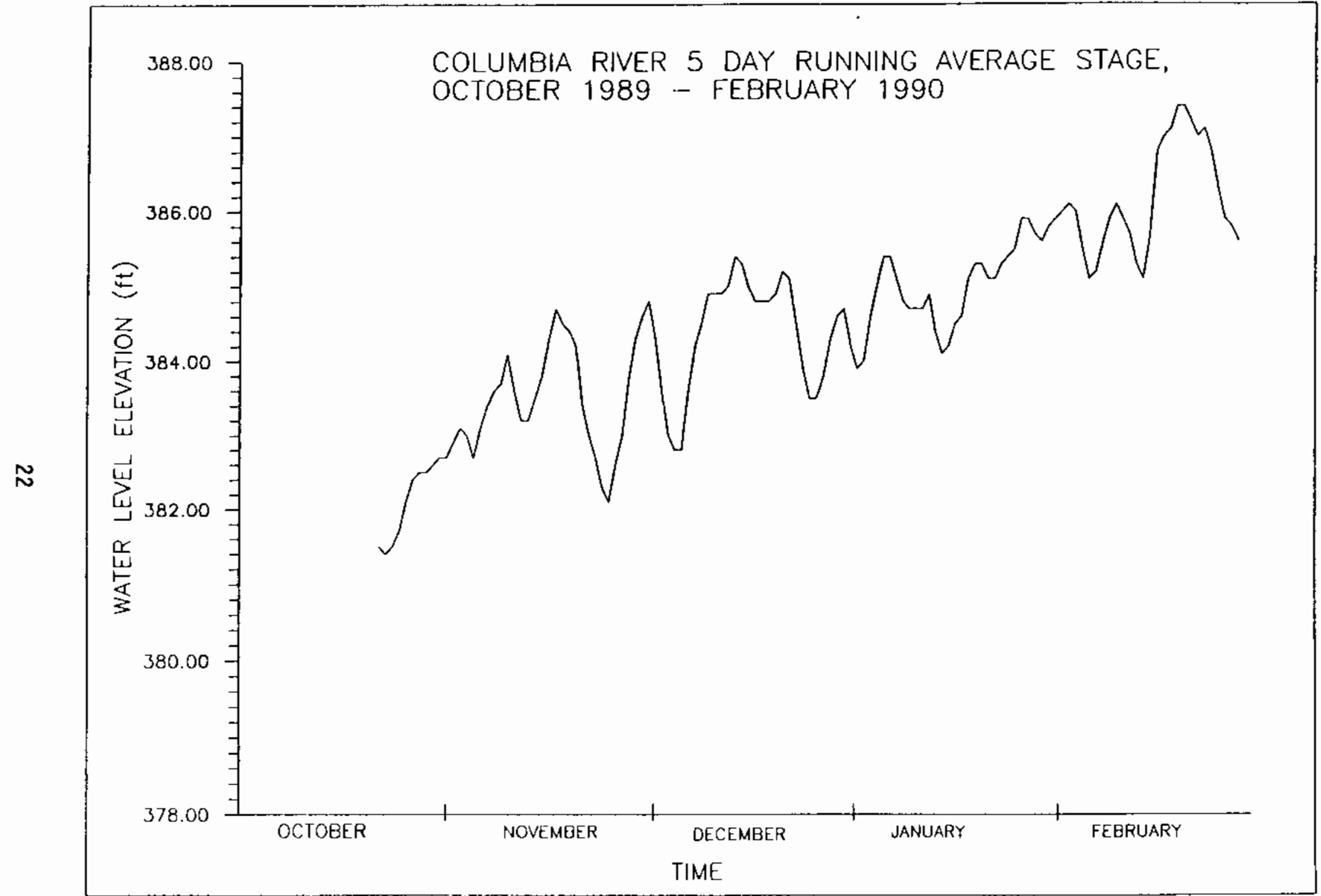

EIGURE 7. Columbia River 5-Day Average Stage, October 1989-February 1990 
located approximately 2000 feet away from the 1324-N/NA facility. Wells 199-N-3, 199-N-8S, and 199-N-8P do not have enough data to determine long-term rise or fall in water level.

Barometric effects can also affect the water-table fluctuations. These effects may, however, be masked by the influence of river stage fluctuations and waste water discharges. Changes in barometric pressure can cause smal1 fluctuations in the water table in unconfined aquifers (Peck 1960). Figure 8 shows hourly water-level elevations at we 11 199-N-34 versus hourly barometric pressure data from the Hanford meteorology station in the 200 West Area. As indicated, there is no apparent correlation between water-level fluctuations and changes in barometric pressure. All wells screened in the same strata in the 100-N Area would also be expected to respond similarly to barometric pressure changes. 


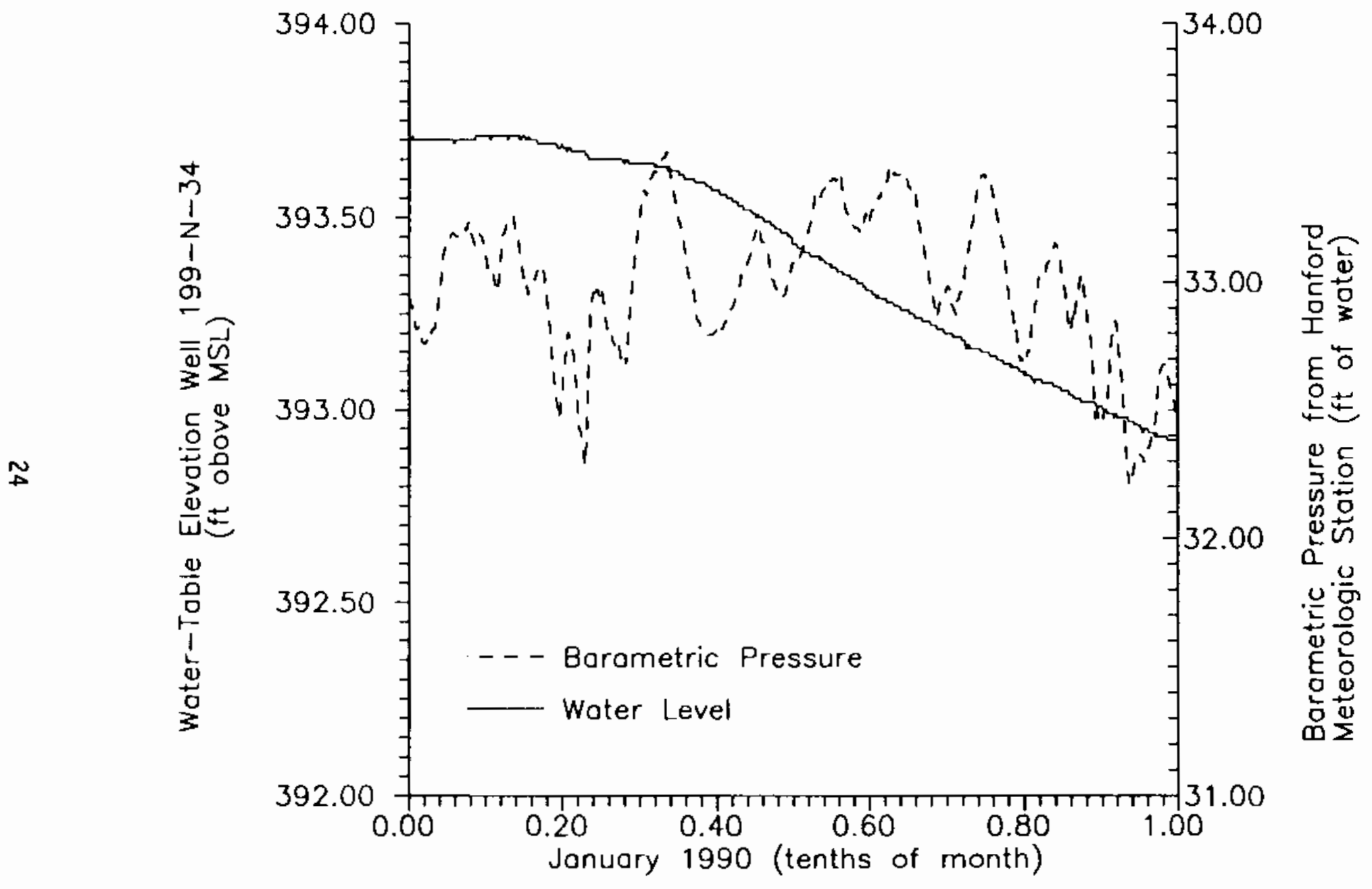

EIGURE 8. Hourly Water-Level Elevations Versus Hourly Barometric Pressure Data for Well 199-N-34 


\section{STATISTICAL ANALYSIS}

A statistical analysis was applied to the water-level data to correlate the water-level fluctuations observed in the wells with the river stage fluctuations recorded at the gaging station. The purpose of the statistical analysis was to quantify the relationship between these water-level fluctuations, which can be used to evaluate the influence of the river stage on the water table.

\section{METHOD}

The statistical procedure used to evaluate the river stage and welT water-level fluctuations is a fast Fourier transform (FFT) algorithm using a verified program taken from Press et al. (1986). This algorithm allows for rapid digital processing on a microcomputer (Brigham 1974). The FFT procedure applies a transformation to the data by separating the waveforms into a sum of sinusoids of different frequencies.

The transformed data (the river stage data and the water-level data from each of the wells for the same discrete time period) are cross-correlated to determine the time lag and dampening effects as a result of river stage fluctuations propagating into the unconfined aquifer inland from the river. The data are cross-correlated by shifting one of the data sets relative to the other data set in discrete time steps and calculating the covariance for each shift using the FFT procedure. The time lag is equal to the number of time steps at which the maximum covariance occurs multiplied by the water-level time interval. The dampening effect, referred to by Bendat and Piersol (1986) as the attenuation factor, $\alpha$, is related to the maximum covariance by the equation

$$
\alpha=\operatorname{Cov}_{\mathrm{m}} / \sigma_{\mathrm{x}}{ }^{2}
$$

where $\operatorname{Cov}_{\mathrm{m}}=$ maximum covariance

$\sigma_{x}=$ standard deviation of the first data set (river stage data). 
Prior to data transformation, the data were normalized by subtracting the mean for the entire time period from the data. Basic statistics were applied to the normalized data to determine the standard deviation, covariance, and correlation. The correlation is related to the covariance and standard deviation of the two data sets by the equation

$$
\operatorname{Cor} r=\operatorname{Cov} / \sigma_{\mathrm{x}} \sigma_{\mathrm{y}}
$$

where $\operatorname{Cov}=$ covariance

$\sigma_{\mathrm{x}}=$ standard deviation of the first data set (river stage data)

$\sigma_{y}=$ standard deviation of the second data set (well water-level data).

The covariance is defined as follows:

$$
\operatorname{Cov}=(n * \Sigma x y-\Sigma x * \Sigma y) /(n(n-1))
$$

where $n=$ number of samples

$x=$ data values for the first data set (river stage data)

$y=$ data values for the second data set (well water-level data).

\section{RESULTS}

Statistical analysis was applied to water-level data obtained for the period January 10 through January 31,1989 . This period was chosen because the river stage fluctuations observed between January 10 and January 31,1989 , are typical of short-term river stage fluctuations commonly observed along the Hanford reach. Also, the program requires the number of values for each data set to be a power of 2 . A sampling frequency of 1 hour over a period of approximately 21 days yields $512\left(2^{9}\right)$ data values. This number of data over the 21-day period is sufficient for the statistical analysis. The results of the statistical parameter analysis are tabulated in Table 4. 
IABLE 4. Results of Statistical Parameter Analys is Between the River Stage Fluctuations and the Well Water-Level Fluctuations for January 10 Through January 31, 1989

\begin{tabular}{|c|c|c|c|c|}
\hline Well Name & $\begin{array}{l}\text { Distance to } \\
\text { River, ft }\end{array}$ & Correlation & $\begin{array}{l}\text { Approximate } \\
\text { Iime Lag. hr }\end{array}$ & $\begin{array}{l}\text { Attenuation } \\
\text { Factor } \\
\end{array}$ \\
\hline $199-N-8 S$ & 80 & 0.98 & $<1$ & 0.51 \\
\hline $199-N-8 P$ & 80 & 0.94 & 1 & 0.24 \\
\hline $199-N-51$ & 380 & 0.85 & 2 & 0.29 \\
\hline $199-N-25$ & 310 & 0.77 & 3 & 0.34 \\
\hline $199-N-20$ & 430 & 0.64 & 7 & 0.19 \\
\hline $199-N-23$ & 410 & 0.48 & 15 & 0.13 \\
\hline $199-N-27$ & 5280 & -0.50 & - & $\cdots$ \\
\hline $199-N-34$ & 2690 & -0.50 & -- & -. \\
\hline $199-N-58$ & 2480 & 0.06 & -- & $\cdots$ \\
\hline $199-N-67$ & 1450 & -0.50 & $\cdots$ & -. \\
\hline
\end{tabular}

As expected, the results in Table 4 indicate strong correlation between the river stage fluctuations with the water-level fluctuations observed in piezometers $199-\mathrm{N}-8 \mathrm{~S}$ and $199-\mathrm{N}-8 \mathrm{P}$ (10cated approximately $80 \mathrm{ft}$ from the river) and wells 199-N-20, 199-N-23, 199-N-25, and 199-N-51 (located between $130 \mathrm{ft}$ and $480 \mathrm{ft}$ from the river) (i.e., prior to data transformation). The highest correlation is exhibited for wells 199-N-8S, 199-N-8P, and 199-N-5I. Correlations ranged between 0.48 and 0.98 on a scale normalized between 0 , which represents no correlation, and 1 , which represents perfect correlation. The correlations determined for we17s 199-N-27, 199-N-34, 199-N-58, and 199-N-67, located between $860 \mathrm{ft}$ and $2570 \mathrm{ft}$ from the river, indicate that the waterlevel fluctuations observed in these wells do not correlate with the river stage fluctuations. The correlation for those wells ranges between -0.50 and 0.06 .

The approximate time lag at which maximum covariance occurs and the attenuation factor associated with each of the wells exhibiting a strong correlation between water-level and river stage fluctuations is also listed in Table 4. Time lags ranged from less than $1 \mathrm{~h}$ to as much as $15 \mathrm{~h}$ with the attenuation factors (a dimensionless parameter) ranging between 0.13 and 0.51 . The time $\mathrm{lag}$ is the time after which the water level in the well responds to a 
corresponding change in the river stage. The value for the attenuation factor becomes smaller with greater attenuation and ranges between 0 and 1 . A value of 1 represents no attenuation and a value of 0 represents complete attenuation.

Waveform characteristics of the observed water-level fluctuations at various distances from the river indicate that the medium through which the river flood waves are propagated is not homogeneous. The results in Table 4 indicate that the water-level fluctuations observed in well 199-N-51, located approximately $50 \mathrm{ft}$ farther from the river than well 199-N-20, are much more responsive to the river stage fluctuations as indicated by a smaller time lag, greater attenuation factor, and higher correlation. Strong correlation exhibited for well 199-N-51 suggests that river stage fluctuations propagate farther inland from well $199-\mathrm{N}-51$ (greater than $480 \mathrm{ft}$ ). The results in Table 4 also indicate that the water-level fluctuations observed in well 199-N-23, located closer to the river than wells $199-\mathrm{N}-20$ and 199-N-51, are less responsive to the river stage fluctuations as indicated by a greater time lag, smaller attenuation factor, and weaker correlation. The lack of correlation with wel1 199-N-27 supports Jensen's (1987) conclusion that river stage has little effect on the ground-water levels close to the $1325-\mathrm{N}$ facility. 


\section{CONCLUSIONS}

The unconfined ground-water flow system beneath the $1301-\mathrm{N}$ facility and the I00-N Area is affected by a number of factors including geologic facies changes, Columbia River stage fluctuations, and artificial recharge from adjacent waste-water disposal facilities. Water-table elevation data indicate that water-levels beneath the 1301-N facility have declined approximately $2 \mathrm{ft}$ from October 1989 to January 1990 and that the ground-water mound under the I325-N facility that existed prior to the "dry layup" status of the N Reactor has 1 argely dissipated. The current dominant water-table feature in the $100-\mathrm{N}$ Area is the ground-water mound under the 1324-N/NA ponds. Ground-water flow is strongly influenced by this mound. The steepest gradients in the watertable elevations are from the $1324-N / N A$ facilities to the river.

Statistical analysis of the water-level data contained in this report indicates that strong correlation between river stage and the water-table fluctuations are exhibited in wells located between 130 and $480 \mathrm{ft}$ from the river. Wells located between 860 and 2570 feet from the river do not indicate significant association between water-level fluctuations and river stage elevation. The time lag between river stage changes and the corresponding effects in the wells located 130 to $480 \mathrm{ft}$ from the river range from less than $1 \mathrm{~h}$ up to $15 \mathrm{~h}$. Attenuation of these responses range from 0.13 to 0.51 . Generally the time lags and attenuation increase with distance from the river with the exception of well 199-N-51. The correlation coefficients of responses to the river in well 199-N-51, which is 480 feet from the river, are similar to wells that are located much closer to the river but several thousand feet south of well 199-N-5I. This response suggests other factors such as hydrogeological properties of the aquifer are controlling the behavior of the wave propagation induced by river stage fluctuations. Lithologic sample descriptions indicate that relatively finer grained sediments occur between the river and the 1301-N facility than those occurring north of the facility near well 199-N-51. These finer-grained sediments result in lower transmissivities near the $1301-N$ facility than in the area to the north.

Impacts of river stage fluctuations on the ground-water system beneath the 130l-N facility were not evident during the period of study. Water levels 
in the vicinity of the 1301-N facility are predominantly influenced by the regional gradient and the ground-water mound beneath 1324-N/NA facility.

other factors, such as barometric effects, do not have a significant influence on the water-table elevations. 


\section{REFERENCES}

Baker, V. R. 1973. Paleohydrology and Sedimentology of Lake Missoula Flooding in Eastern Washington. Special Paper 144, GeoTogical Society of America, Boulder, Colorado.

Bendat, J. S. and A. G. Piersol. 1986. Random Data: Analysis and Measurement Procedures. 2nd ed. John Wiley \& Sons, Inc., New York.

Bjornstad, B. N. 1984. Suprabasalt Stratigraphy within and Adjacent to the Reference Repository Location. SD-BWI-DP-039, Rockwe11 Hanford Operations, Richland, Washington.

Bjornstad, B. N. 1985. "Late-Cenozoic Stratigraphy and Tectonic Evolution Within a Subsiding Basin, South-Central Washington." Geological Society of America Abstracts with Programs 17:524.

Bretz, J. H. 1959. Washington's Channeled Scabland. Washington Division of Mines and Geology Bulletin 45, 01ympia, Washington.

Brigham, E. 0. 1974. The Fast Fourier Transform. Prentice-Hall, Inc., Englewood Cliffs, New Jersey.

Brown, D. J. 1959. Subsurface Geology of the Hanford Separations Area. HW-61780, General Electric Hanford Atomic Products Operation, Richland, Washington.

COE. 1984. Columbia River Basin Master Water Control Manual. U.S. Army Corp of Engineers, North Pacific Division, Portland, Oregon.

DOE. 1988. Environmental Assessment: Reference Repository Location, Hanford Site, Washington. DOE/RW-0070, U.S. Department of Energy, Washington, D.C.

Fruland, R. M., D. J. Bates, and R. E. Lundgren, eds. 1989a. Resource Conservation and Recovery Act Ground-Water Monitoring Projects for Hanford Facilities: Progress Report for the Period July 1 to September 30, 1988. PNL-6789, Pacific Northwest Laboratory, Richland, Washington.

Fruland, R. M., D. J. Bates, and R. E. Lundgren, eds. 1989b. Resource Conservation and Recovery Act Ground-Water Monitoring Projects for Hanford Facilities: Progress Report for the Period October 1 to December 31, 1988 . PNL-6844, Pacific Northwest Laboratory, Richland, Washington.

Gee, G. W., and P. R. Heller. 1985. Unsaturated Water Flow at the Hanford Site: A Review of Literature and Annotated Bibliography. PNL-5428, Pacific Northwest Laboratory, Richland, Washington.

Gephart, R. E., R. C. Arnett, R. G. Baea, L. S. Leonhart, and F. A. Spane, Jr. 1979. Hydrologic Studies Within the Columbia Plateau, Washington: An Integration of Current Know7edge. RH0-BWI-ST-5, Rockwell Hanford Operations, Richland, Washington. 
Gilmore, T. J., 1989. Groundwater Quality Assessment Program for the 1324-N/NA Facilities. WHC-SD-EN-AP-005 Rev. 0, prepared by Pacific Northwest Laboratory for Westinghouse Hanford Company, Richland, Washington.

Gilmore, T. J., and E. J. Jensen. 1989. Groundwater Quality Assessment Program for the 1301-N Facility. WHC-SD-EN-AP-004 Rev. 0, prepared by Pacific Northwest Laboratory for Westinghouse Hanford Company, Richland, Washington.

Jensen, E. J. 1987. Summary of Water-Level Measurements Around the 1325-N Crib During the Fall of 1985 and the Winter of 1986-1987. PNL-6374, Pacific Northwest Laboratory, Richland, Washington.

Nelson, R. W. 1964. Analysis of Waste Release by Seepage to the Columbia River from the 1301-N Crib. NW-8136, General Electric Hanford Atomic Products Operation, Richland, Washington.

Newcomer, D. R. 1988. "Detailed Water-Level and an Evaluation of Mathematical Approaches for Near-River Monitoring." Master's thesis, Montana College of Mineral Science, Butte, Montana.

Peck, J. J. 1960. "The Water Table as Affected by Atmospheric Pressure." Journal of Geophysical Research 65:2383-2388.

PNL. 1988a. Ground-Water Monjtoring Compliance Projects for Hanford Site Facilities: Annual Progress Report for 1987. PNL-6678, Pacific Northwest Laboratory, Richland, Washington.

PNL. 1988b. Ground-Water Monjtoring Compliance Projects for Hanford Site Facilities: Progress Report for the Period October 1 to December 31, 1987. PNL-6536, Pacific Northwest Laboratory, Richland, Washington.

PNL. 1988c. Ground-Water Monitoring Compliance Projects for Hanford Site Facilities: Progress Report for the Period January 1 to March 31, 1988. PNL-6581, Pacific Northwest Laboratory, Richland, Washington.

PNL. 1988d. Ground-Water Monitoring Compliance Projects for Hanford Site Facilities: Progress Report for the Period April l to June 30, 1988. PNL-6675, Pacific Northwest Laboratory, Richland, Washington.

Press, W. H., B. P. Flannery, S. A. Teukolsky, and W. T. Vetterling. 1986. Numerical Recipes, The Art of Scientific Computing. Cambridge University Press, New York.

Resource Conservation and Recovery Act of 1976. Public Law 94-580, as amended. 90 Stat. 2795 (Title 42).

Routson, R. C., and K. R. Fecht. 1979. Soil (Sediment) Properties of Twelve Hanford Wells with Geologic Interpretation. RHO-LD-82, Rockwell Hanford Operations, Richland, Washington. 
Smith, R. M., D. J. Bates, and R. E. Lundgren. 1989a. Resource Conservation and Recovery Act Ground-Water Monitoring Projects for Hanford Facilities: Progress Report for the Period January 1 to March 30, 1989. PNL-6957, Pacific Northwest Laboratory, Richland, Washington.

Smith, R. M., D. J. Bates, and R. E. Lundgren. 1989b. Resource Conservation and Recovery Act Ground-Water Monitoring Projects for Hanford Facilities: Progress Report for the Period April l to June 30, 1989. PNL-7134, Pacific Northwest Laboratory, Richland, Washington.

Tallman, A. M., K. R. Fecht, M. C. Marratt, and G. V. Last. 1979. Geology of the Separations Area, Hanford Site, South-Central Washington. RHO-ST-23, RockwelT Hanford Operations, Richland, Washington.

Waitt, R. B., Jr. 1980. "About Forty Last-Glacial Lake Missoula JokulhTaups Through Southern Washington." Journal of Geology 88:653-679. 

APPENDIX A

WATER-TABLE MAPS OF THE UNCONFINED AQUIFER

BENEATH THE 100-N AREA 


\section{APPENDIX A}

\section{WATER-TABLE MAPS OF THE UNCONFINED AQUIFER}

BENEATH THE 100-N AREA

This appendix contains water-level maps of the unconfined aquifer beneath the 100-N Area. Included are five maps for the dates October 31, November 30, December 28, 1989, January 25, 1990, and February 26, 1990, and a we11 location diagram showing the wells used for the water-level maps. Also included

are water-table data for the dates October, November, and December 1989, and January 1990. 
WATER-LEVELS $100 \mathrm{~N}$ AREA - OCTOBER 31, 1989

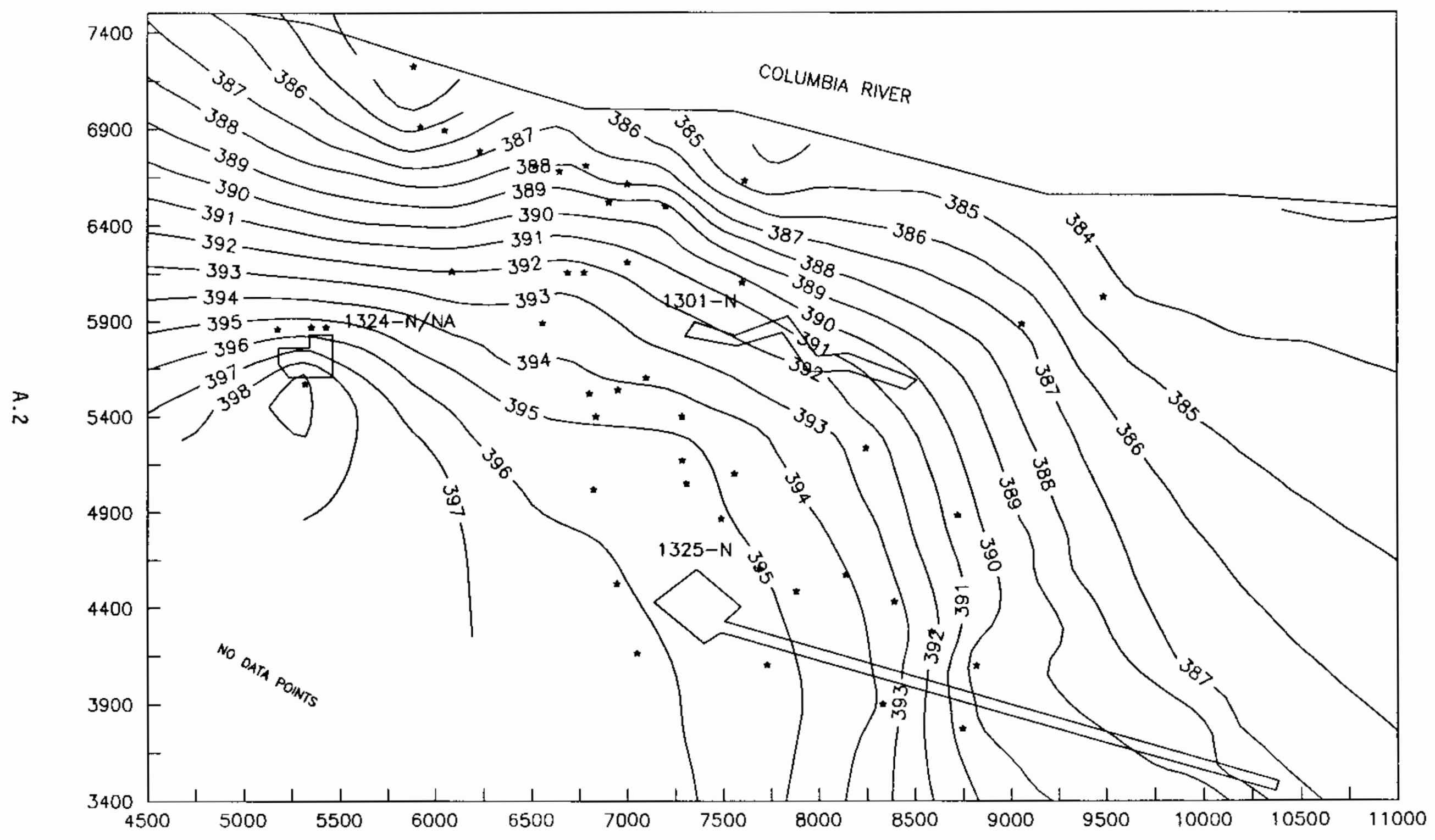


WATER-LEVELS 100 N AREA - NOVEMBER 30, 1989

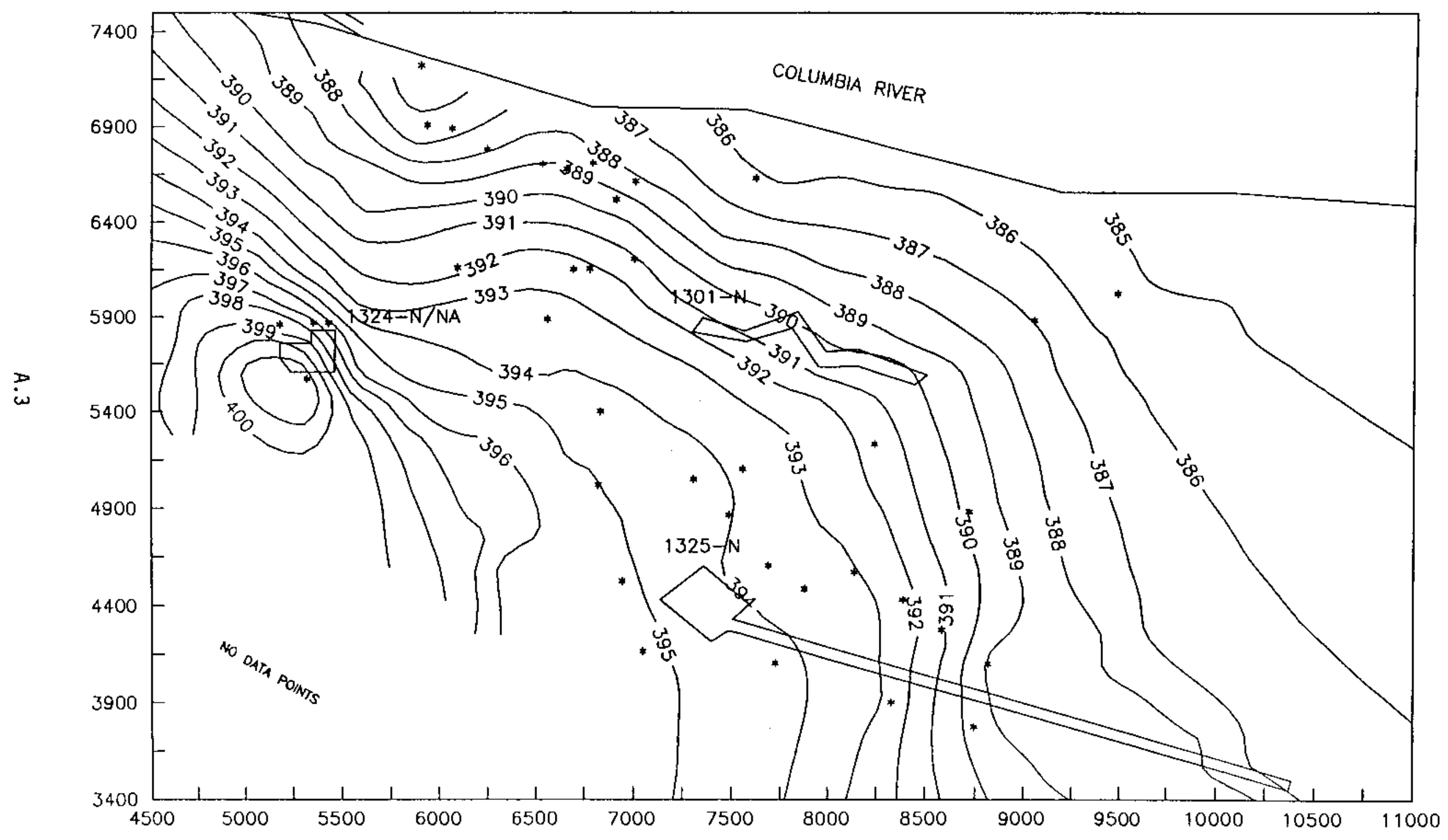


WATER-LEVELS 100 N AREA - DECEMBER 28, 1989

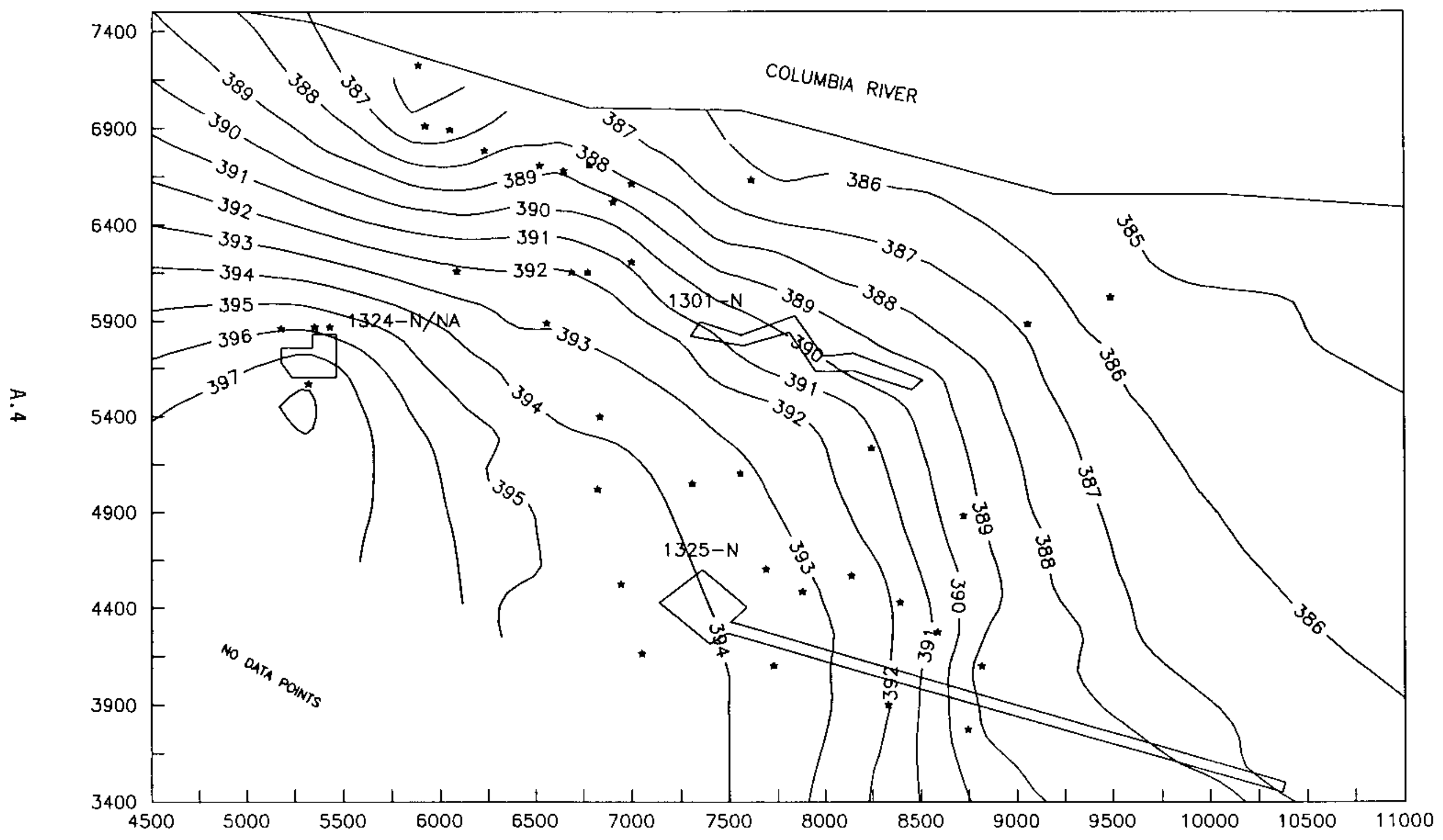


WATER-LEVELS $100 \mathrm{~N}$ AREA - JANUARY 25, 1990

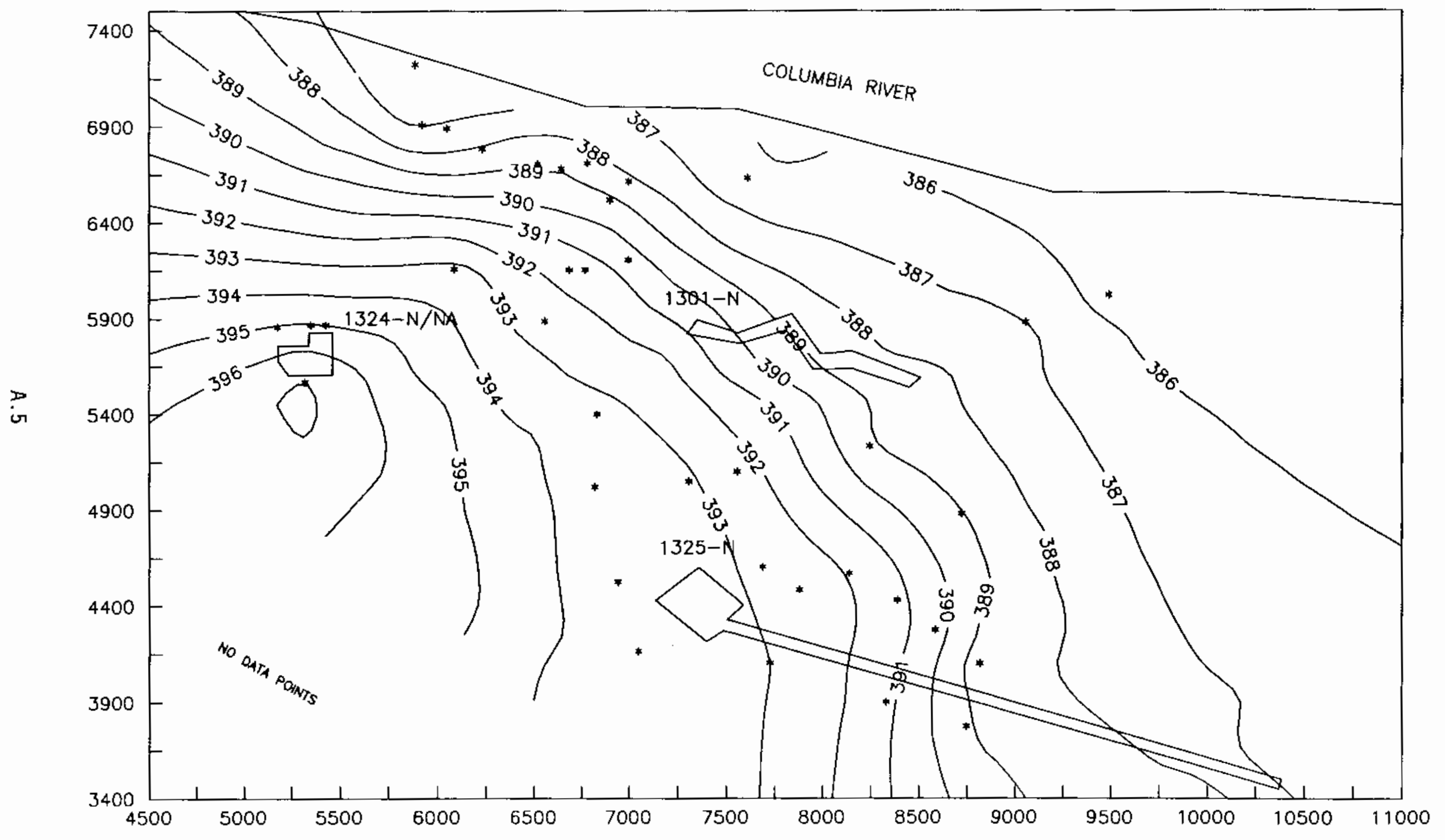




\section{WATER-LEVELS $100 \mathrm{~N}$ AREA - FEBRUARY 26, 1990}

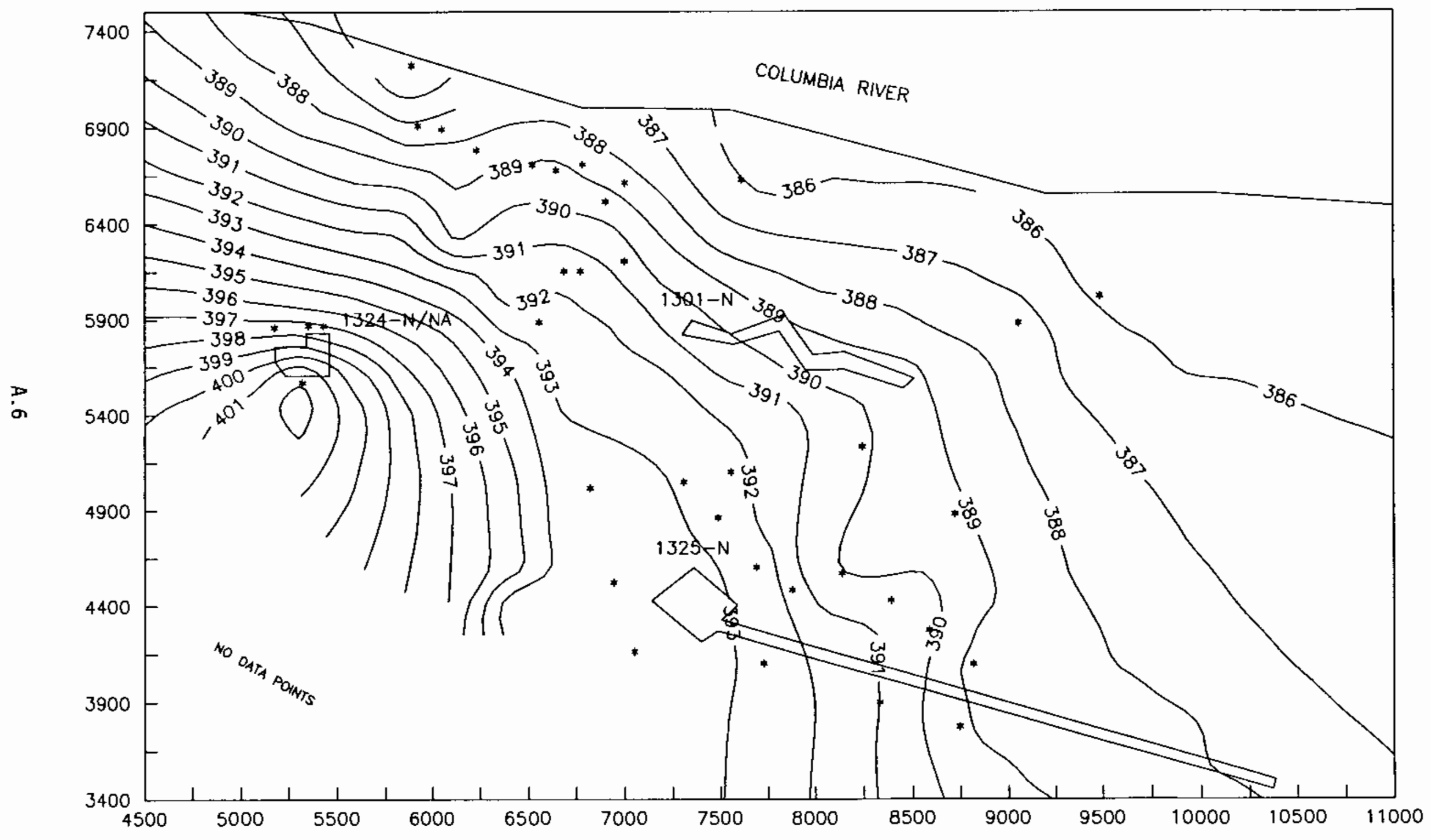


WELLS USED FOR WATER-LEVEL MAPS

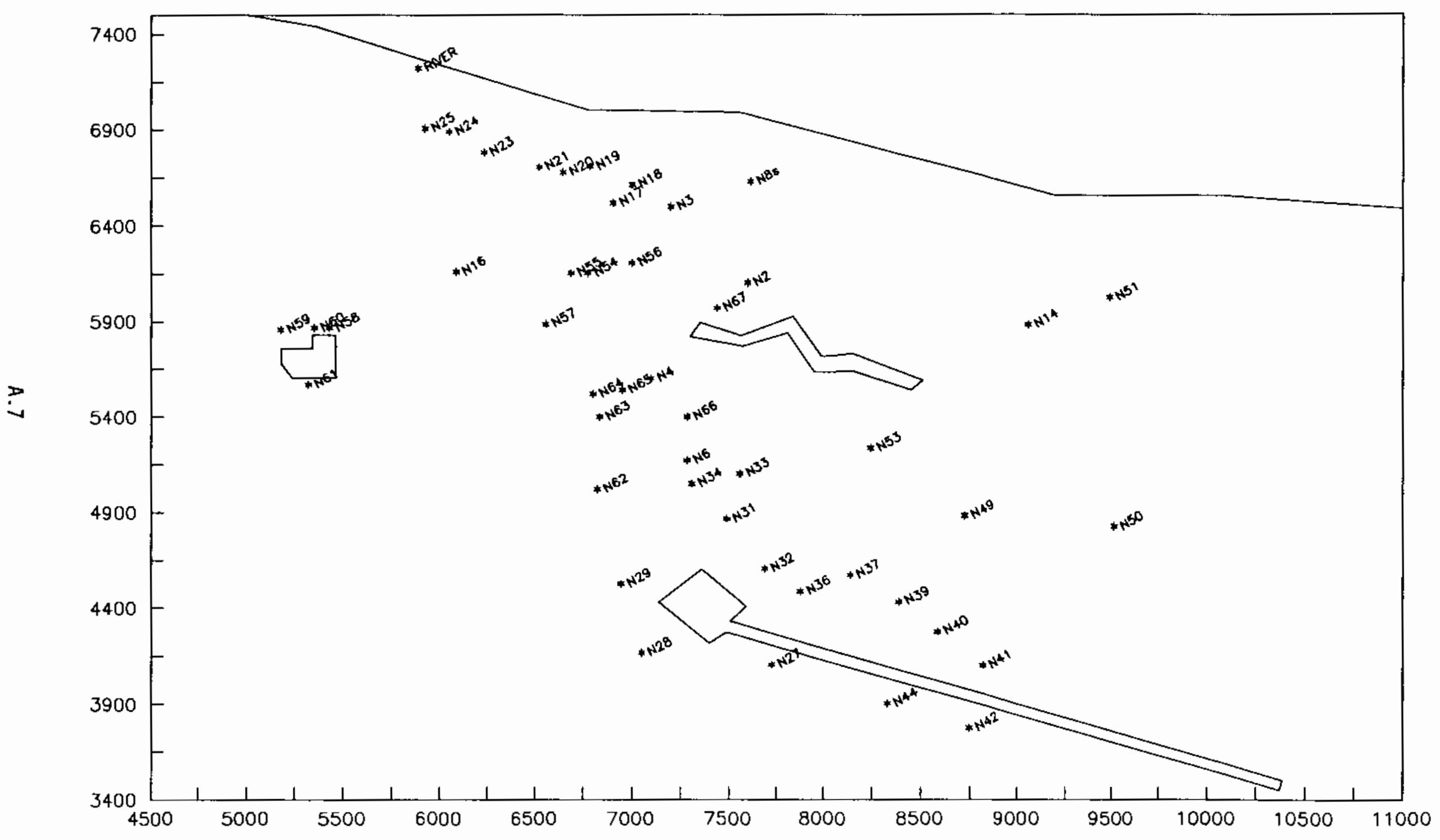


TABLE A.1. Water-Table Data for October 1989

\begin{tabular}{cc}
$\begin{array}{c}\text { Water Table } \\
\text { Elevation }\end{array}$ & $\begin{array}{c}\text { Well Number (al1 wells } \\
\text { prefixed by 199-) }\end{array}$ \\
\cline { 2 - 2 } 390.44 & N2 \\
389.38 & N3 \\
393.93 & N4 \\
395.69 & N6 \\
383.83 & N8s \\
387.00 & N14 \\
392.04 & N16 \\
389.30 & N17 \\
387.71 & N18 \\
387.39 & N19 \\
388.51 & N20 \\
388.20 & N21 \\
386.87 & N23 \\
385.31 & N24 \\
384.45 & N25 \\
395.36 & N27 \\
396.22 & N28 \\
396.08 & N29 \\
395.11 & N31 \\
395.10 & N32 \\
394.74 & N33 \\
395.25 & N34 \\
394.73 & N36 \\
394.25 & N37 \\
393.32 & N39 \\
392.44 & N40 \\
389.42 & N41 \\
390.42 & N42 \\
393.94 & N44 \\
390.47 & N49 \\
384.09 & N51 \\
395.97 & N52 \\
392.66 & N53 \\
392.64 & N54 \\
392.56 & N55 \\
391.42 & N56 \\
393.67 & N57 \\
395.29 & N58 \\
395.36 & N59 \\
395.48 & N60 \\
399.20 & N61 \\
395.84 & N62 \\
395.13 & N63 \\
394.41 & N64 \\
394.06 & N65 \\
394.56 & River \\
383.80 & \\
&
\end{tabular}


TABLE A.2. Water-Table Data for November 1989

\begin{tabular}{|c|c|}
\hline $\begin{array}{l}\text { Water Table } \\
\text { Elevation }\end{array}$ & $\begin{array}{l}\text { We11 Number (all we11s } \\
\text { prefixed by 199-) }\end{array}$ \\
\hline $\begin{array}{l}385.78 \\
387.03 \\
392.97 \\
389.48 \\
388.10 \\
388.19 \\
389.26 \\
389.06 \\
387.87 \\
386.56 \\
386.13 \\
394.33 \\
395.27 \\
395.17 \\
394.14 \\
393.11 \\
393.79 \\
394.35 \\
393.72 \\
393.27 \\
392.49 \\
391.39 \\
388.75 \\
389.38 \\
392.83 \\
389.62 \\
385.17 \\
394.76 \\
391.72 \\
392.43 \\
392.45 \\
391.09 \\
393.46 \\
389.62 \\
398.66 \\
398.78 \\
402.10 \\
395.06 \\
394.49 \\
385.20\end{array}$ & $\begin{array}{l}\text { N8s } \\
\text { N14 } \\
\text { N16 } \\
\text { N17 } \\
\text { N18 } \\
\text { N19 } \\
\text { N20 } \\
\text { N21 } \\
\text { N23 } \\
\text { N24 } \\
\text { N25 } \\
\text { N27 } \\
\text { N28 } \\
\text { N29 } \\
\text { N31 } \\
\text { N32 } \\
\text { N33 } \\
\text { N34 } \\
\text { N36 } \\
\text { N37 } \\
\text { N39 } \\
\text { N40 } \\
\text { N41 } \\
\text { N42 } \\
\text { N44 } \\
\text { N49 } \\
\text { N51 } \\
\text { N52 } \\
\text { N53 } \\
\text { N54 } \\
\text { N55 } \\
\text { N56 } \\
\text { N57 } \\
\text { N58 } \\
\text { N59. } \\
\text { N60 } \\
\text { N61 } \\
\text { N62 } \\
\text { N63 } \\
\text { River }\end{array}$ \\
\hline
\end{tabular}


IABLE A.3. Water-Table Data for December 1989

\begin{tabular}{|c|c|}
\hline $\begin{array}{l}\text { Water Table } \\
\text { Elevation } \\
\end{array}$ & $\begin{array}{l}\text { Well Number (all welis } \\
\text { prefixed by 199-) }\end{array}$ \\
\hline $\begin{array}{l}385.90 \\
386.88 \\
392.23 \\
389.29 \\
388.00 \\
388.01 \\
388.98 \\
388.79 \\
387.72 \\
386.47 \\
386.07 \\
393.66 \\
394.57 \\
394.49 \\
393.46 \\
393.23 \\
393.75 \\
393.11 \\
392.70 \\
391.90 \\
390.89 \\
388.49 \\
389.26 \\
392.21 \\
389.28 \\
385.28 \\
394.08 \\
391.23 \\
392.06 \\
392.07 \\
390.82 \\
392.98 \\
395.66 \\
395.86 \\
395.89 \\
398.25 \\
394.43 \\
393.92 \\
385.50\end{array}$ & 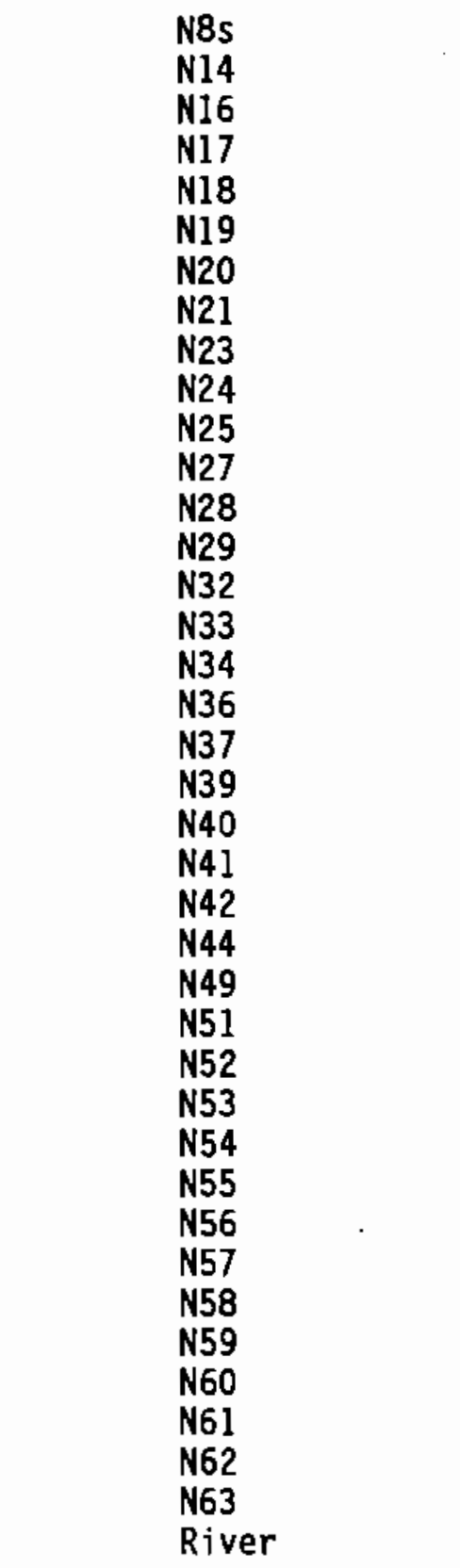 \\
\hline
\end{tabular}


TABLE A.4. Water-Table Data for January 1990

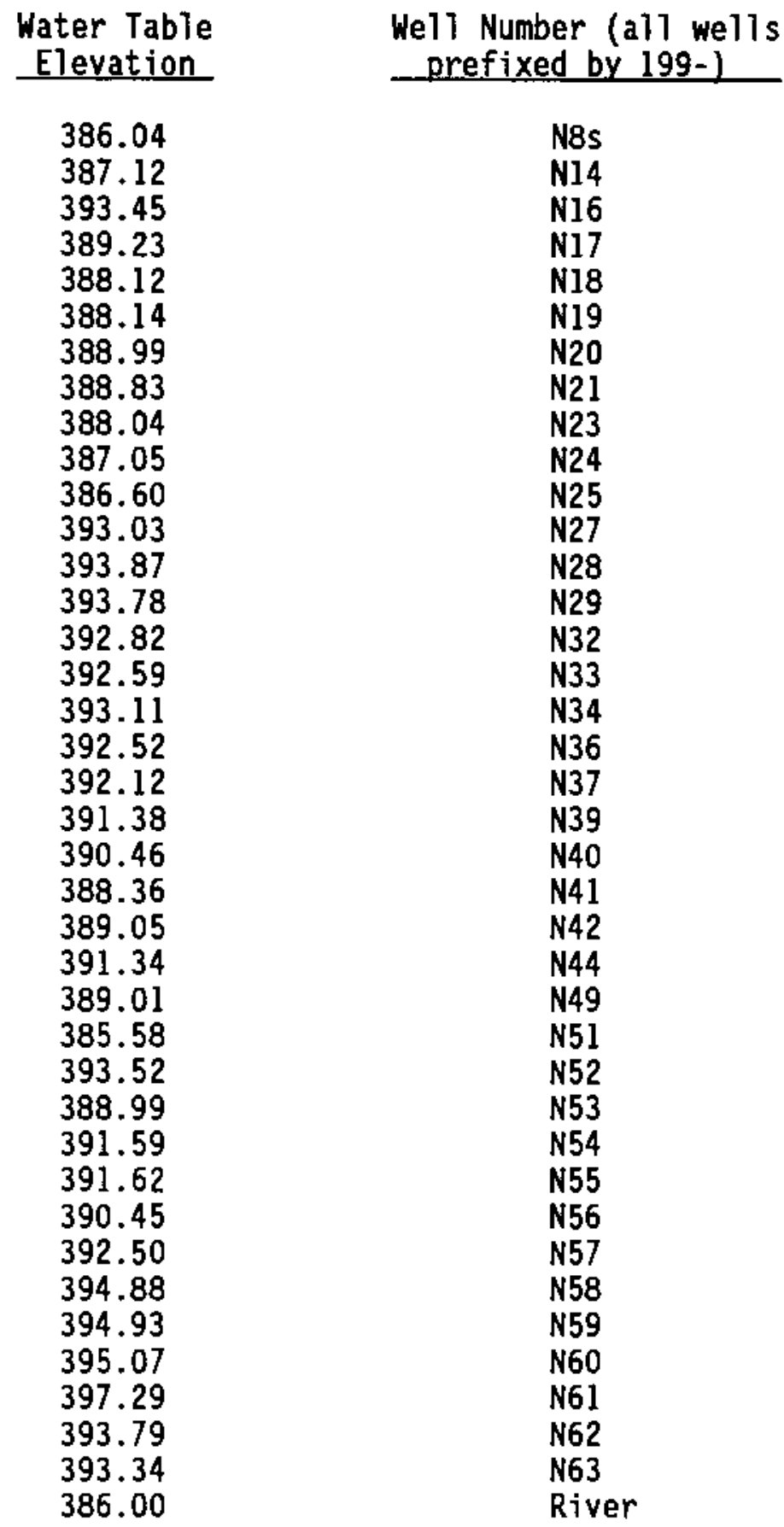

A. 11 


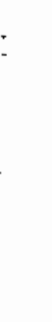




\section{APPENDIX B}

GRAPHS OF HOURLY CDLUMBIA RIVER STAGE DATA

NEAR THE 100-N AREA 


\section{APPENDIX B}

\section{GRAPHS OF HOURLY COLUMBIA RIVER STAGE DATA \\ NEAR THE 100-N AREA}

This appendix contains graphs of hourly Columbia River stage data collected near the 100-N Area for the period October 19, 1989, through February 1990. A 5-day moving average is also plotted on the graph. 


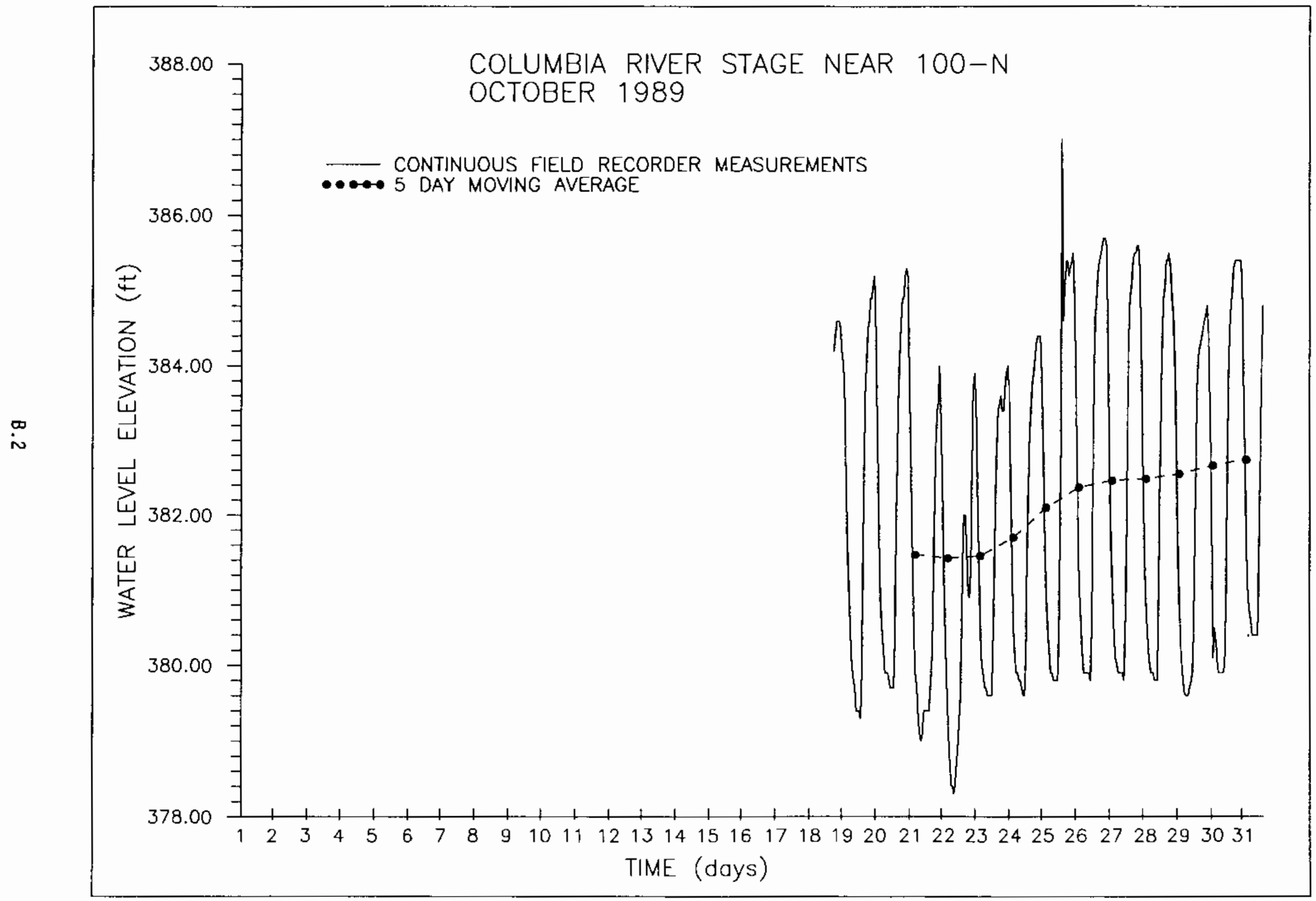




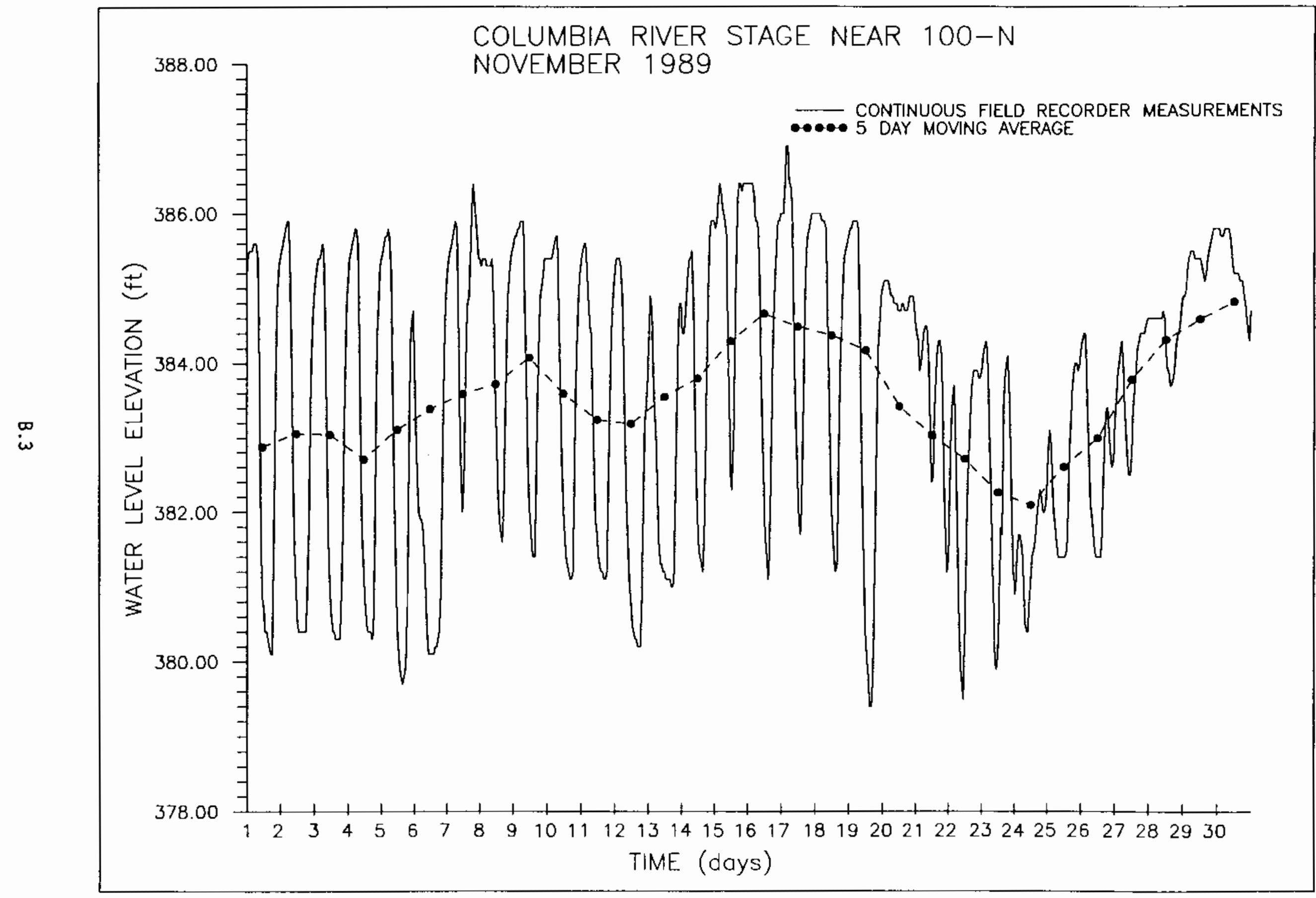




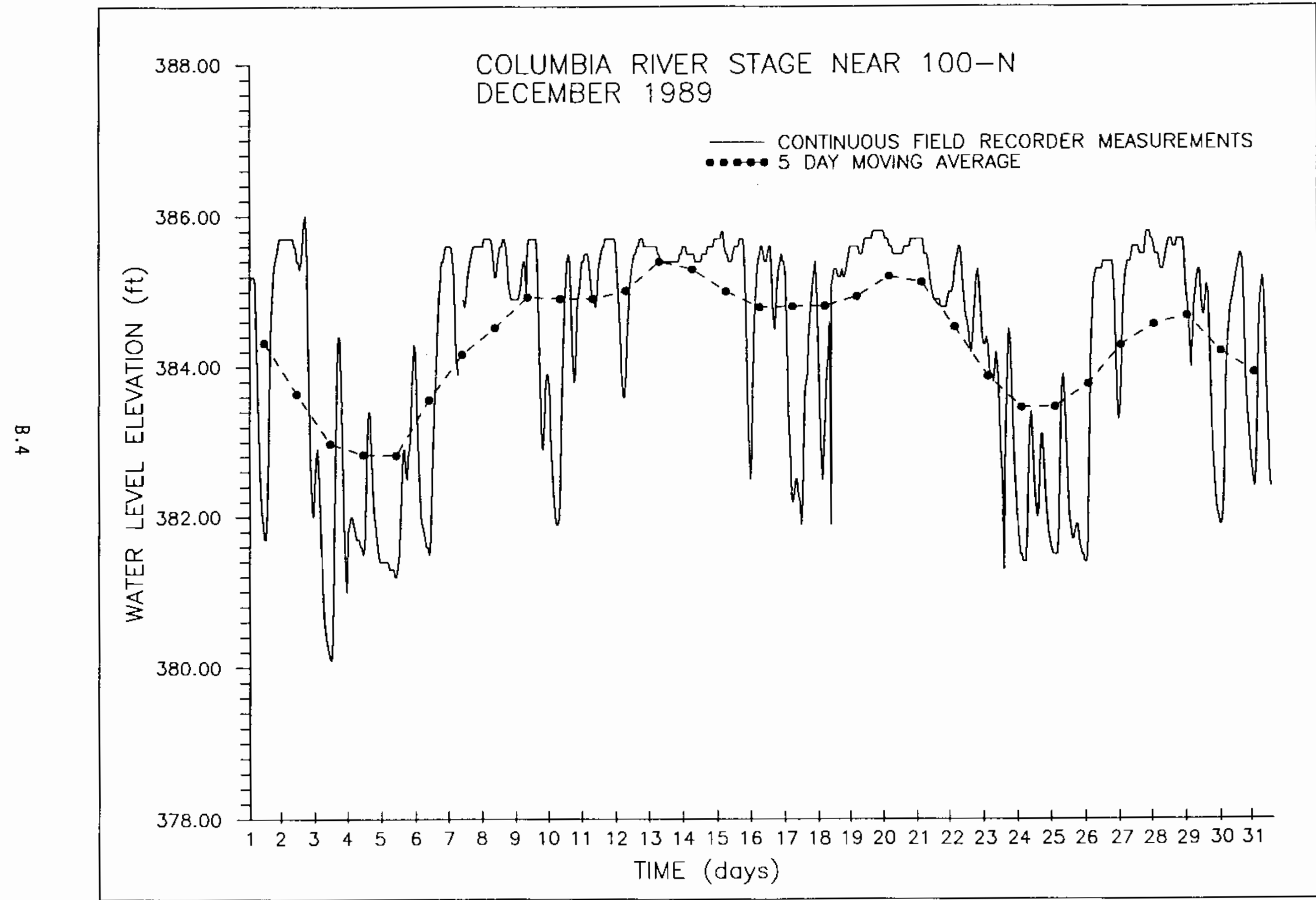




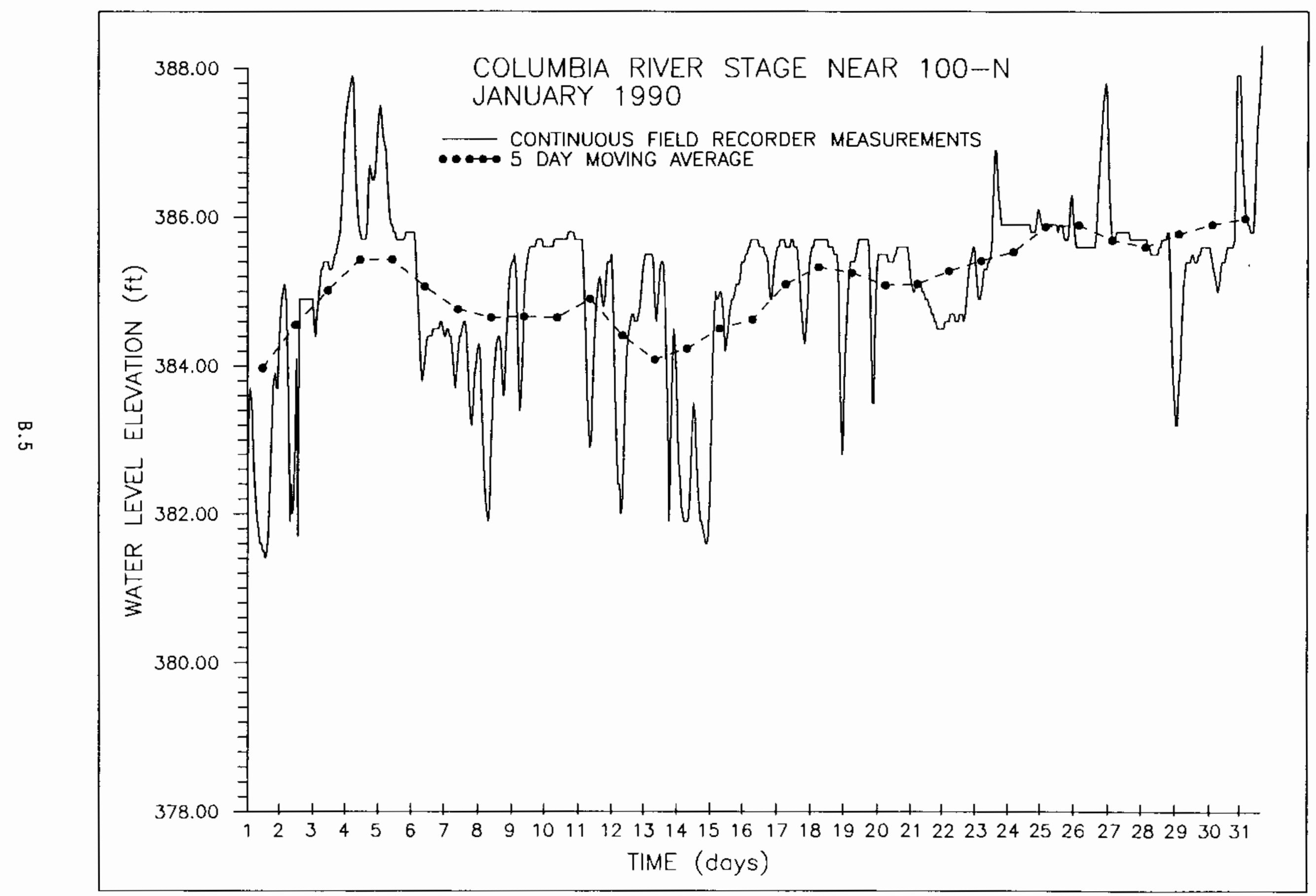




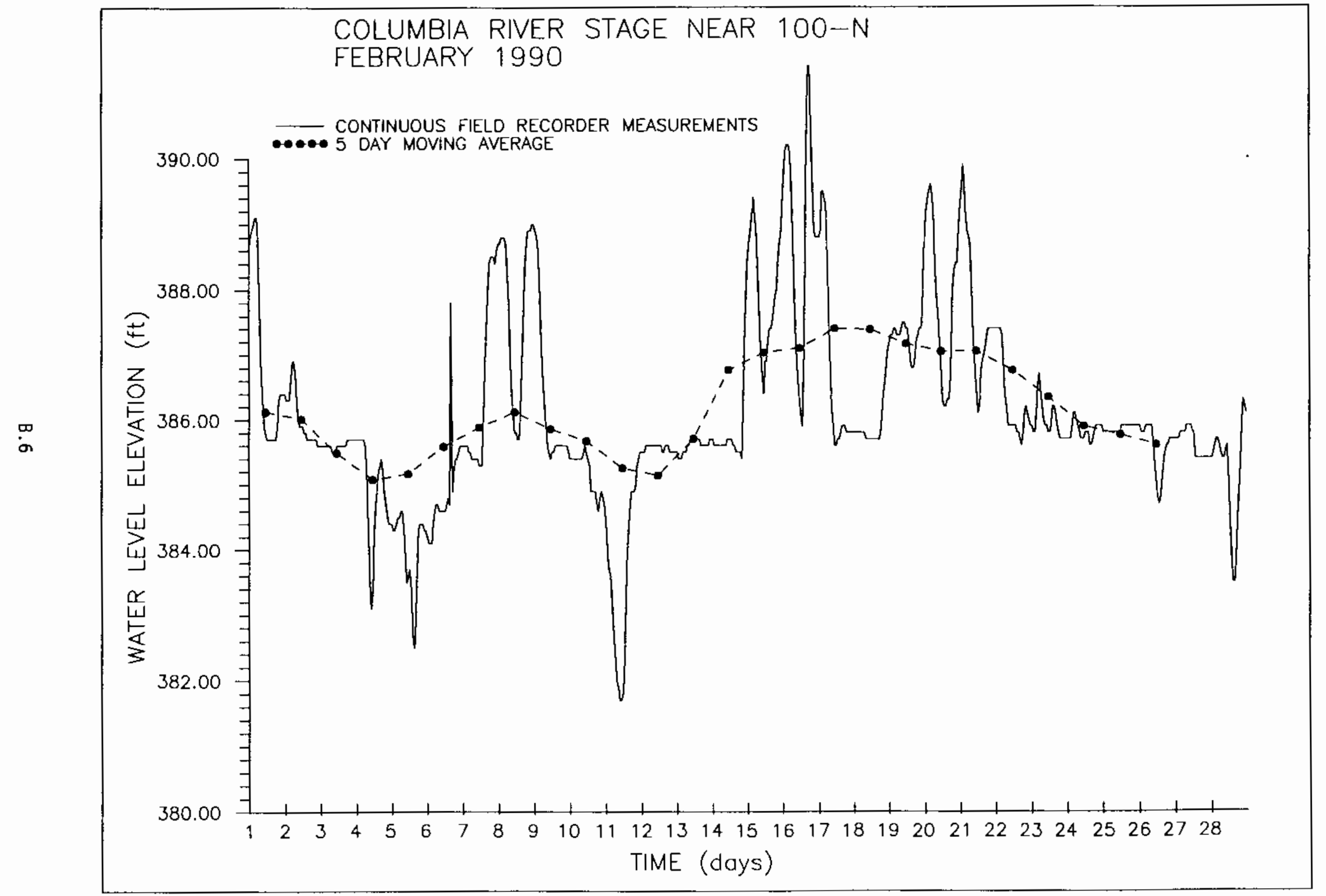


$=$ 


\section{APPENDIX C}

\section{WATER-LEVEL HYDROGRAPHS}

This appendix contains water-level hydrographs for the wells listed below. The well number is abbreviated on the graphs. The prefix 199 is omitted.

\begin{tabular}{c} 
We11 Number \\
\hline$N-03$ \\
$N-8 P$ \\
$N-85$ \\
$N-20$ \\
$N-23$ \\
$N-25$ \\
$N-27$ \\
$N-34$ \\
$N-51$ \\
$N-58$ \\
$N-66$ \\
$N-67$
\end{tabular}

C.1 


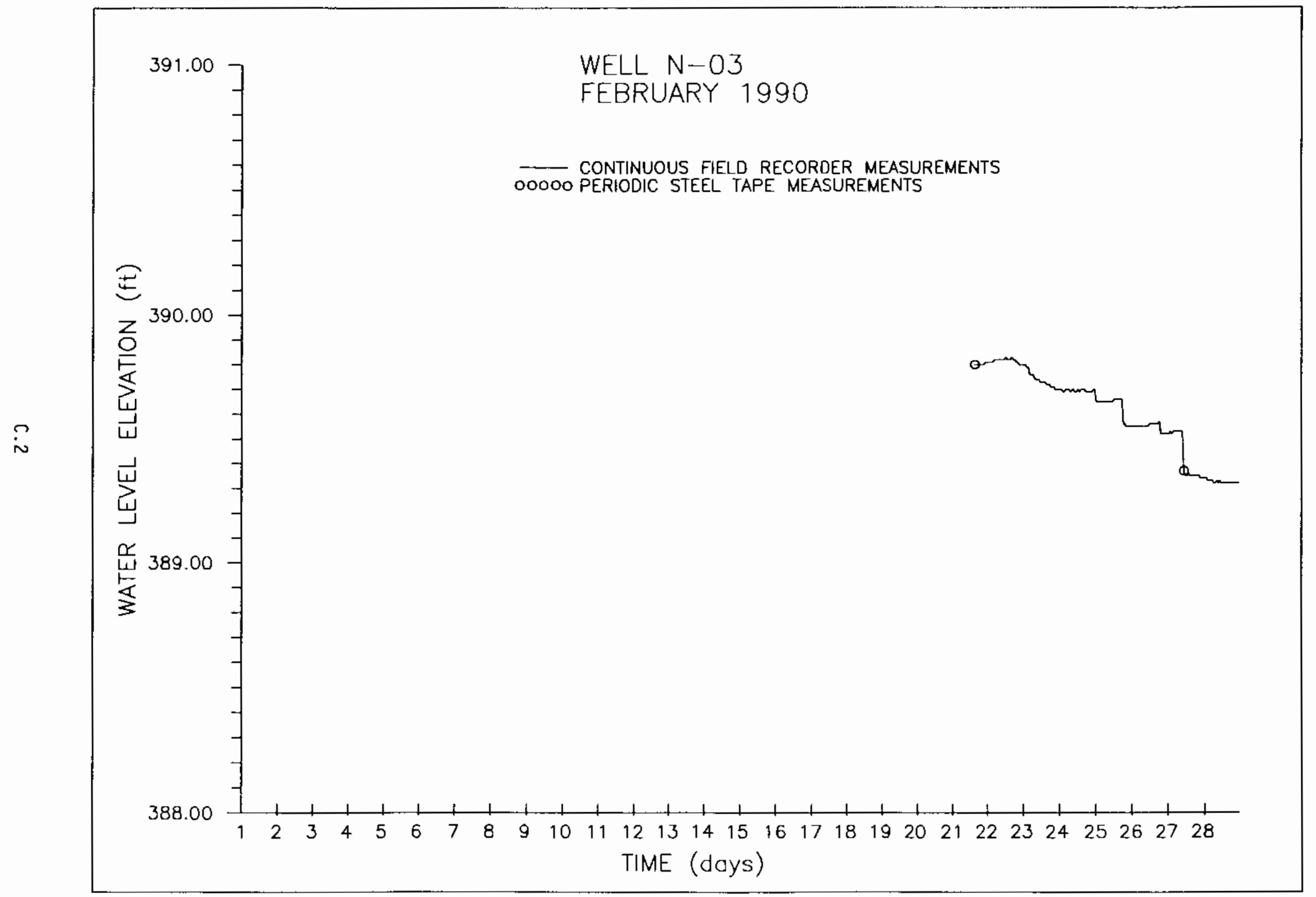




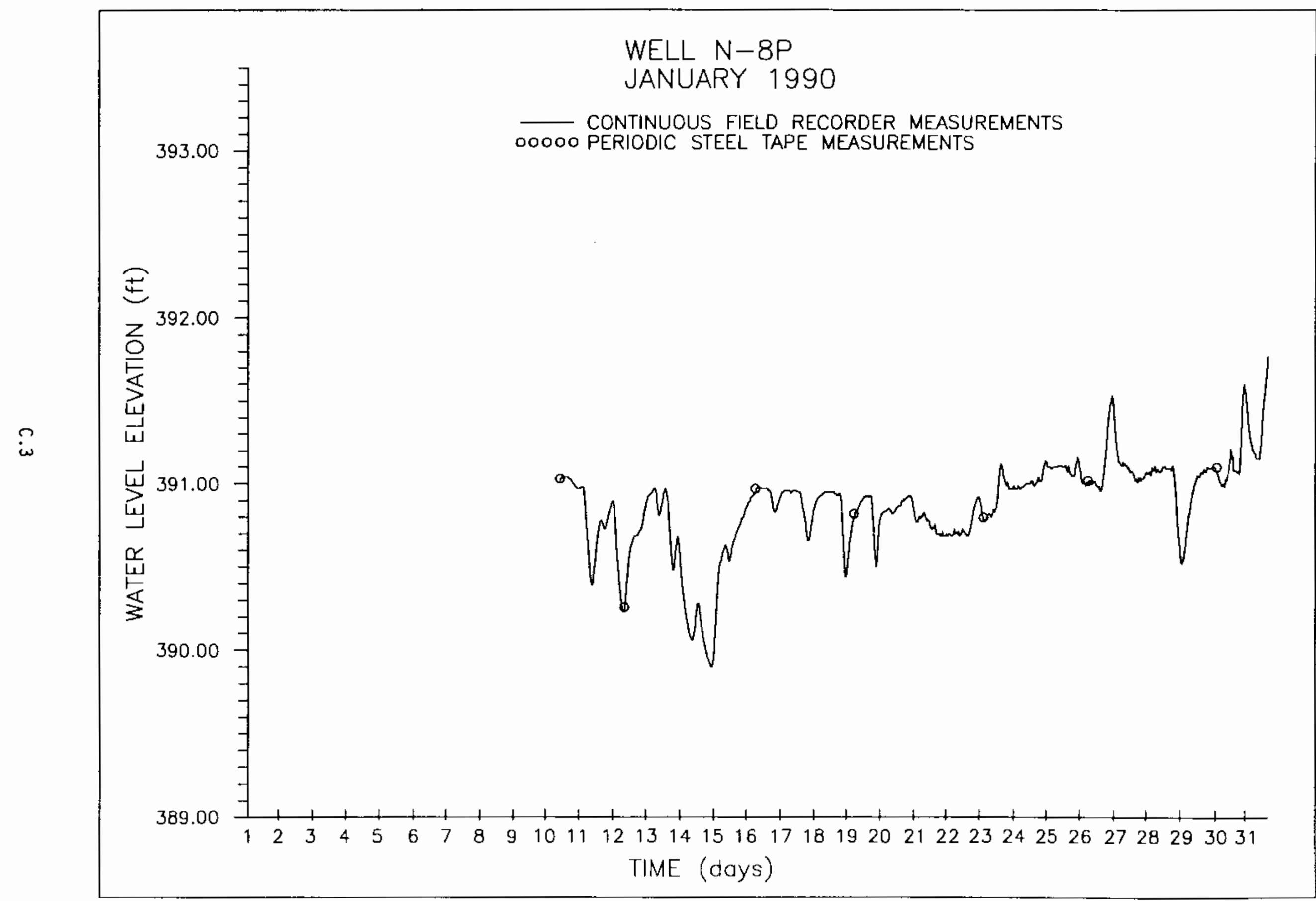




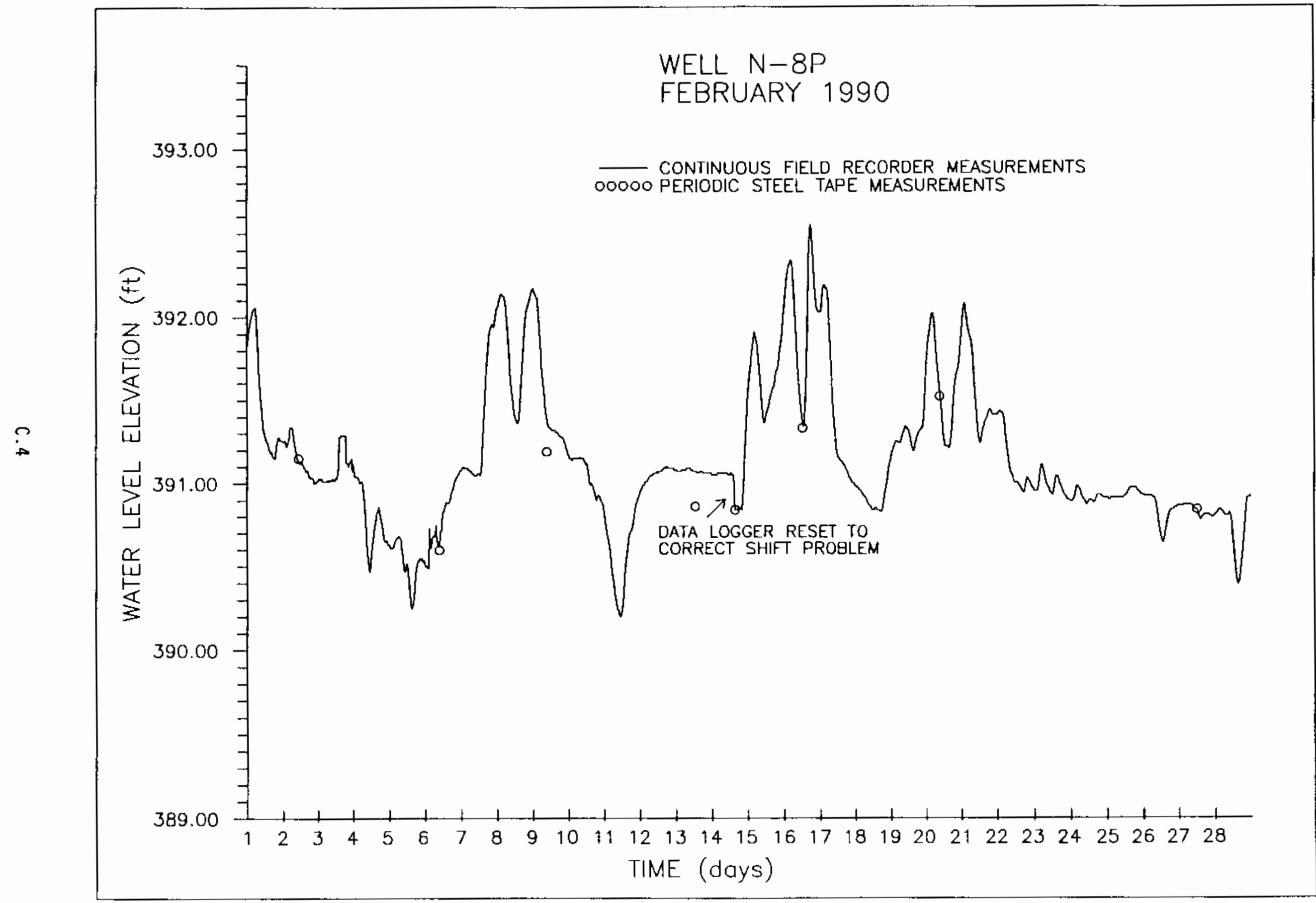




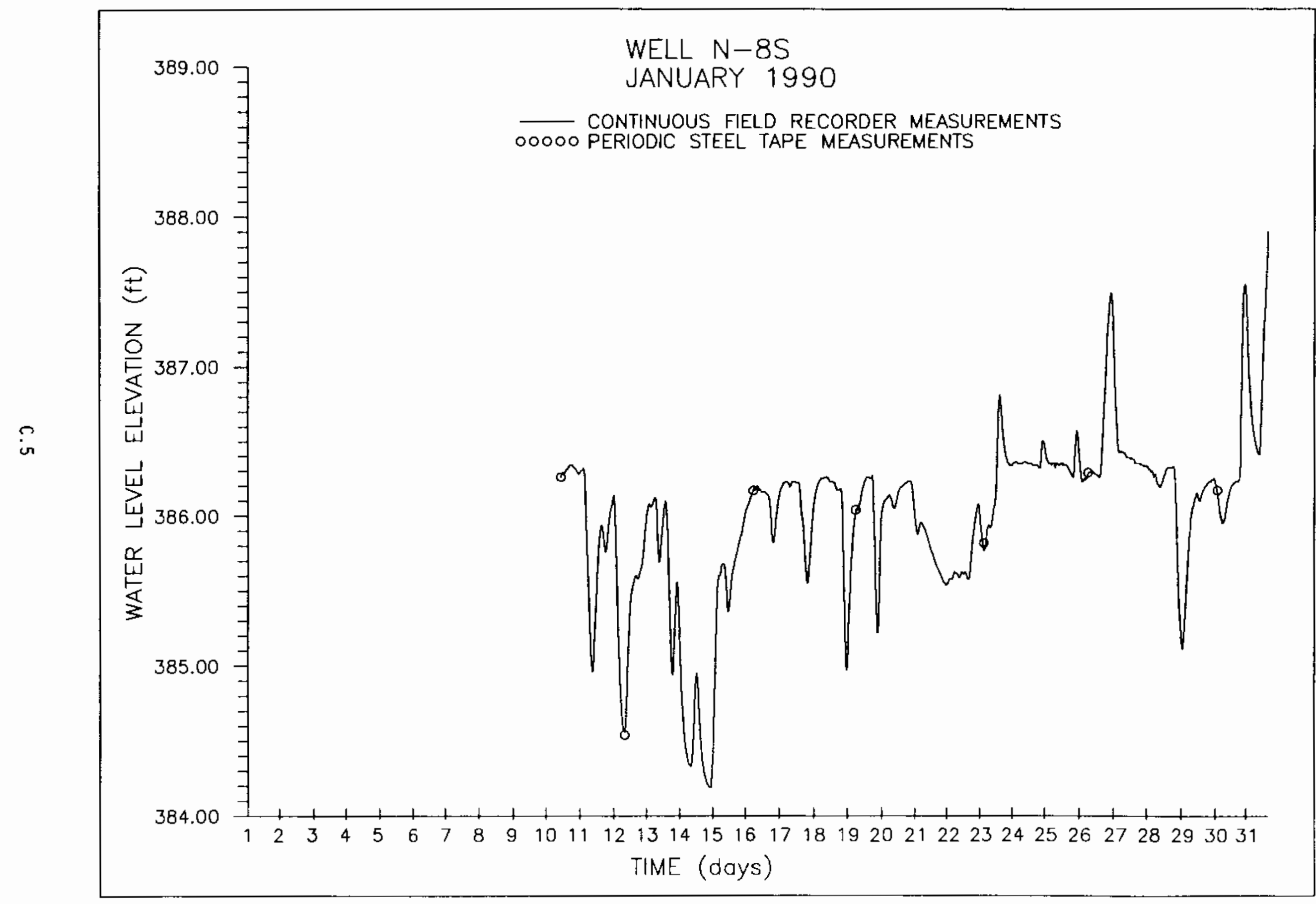




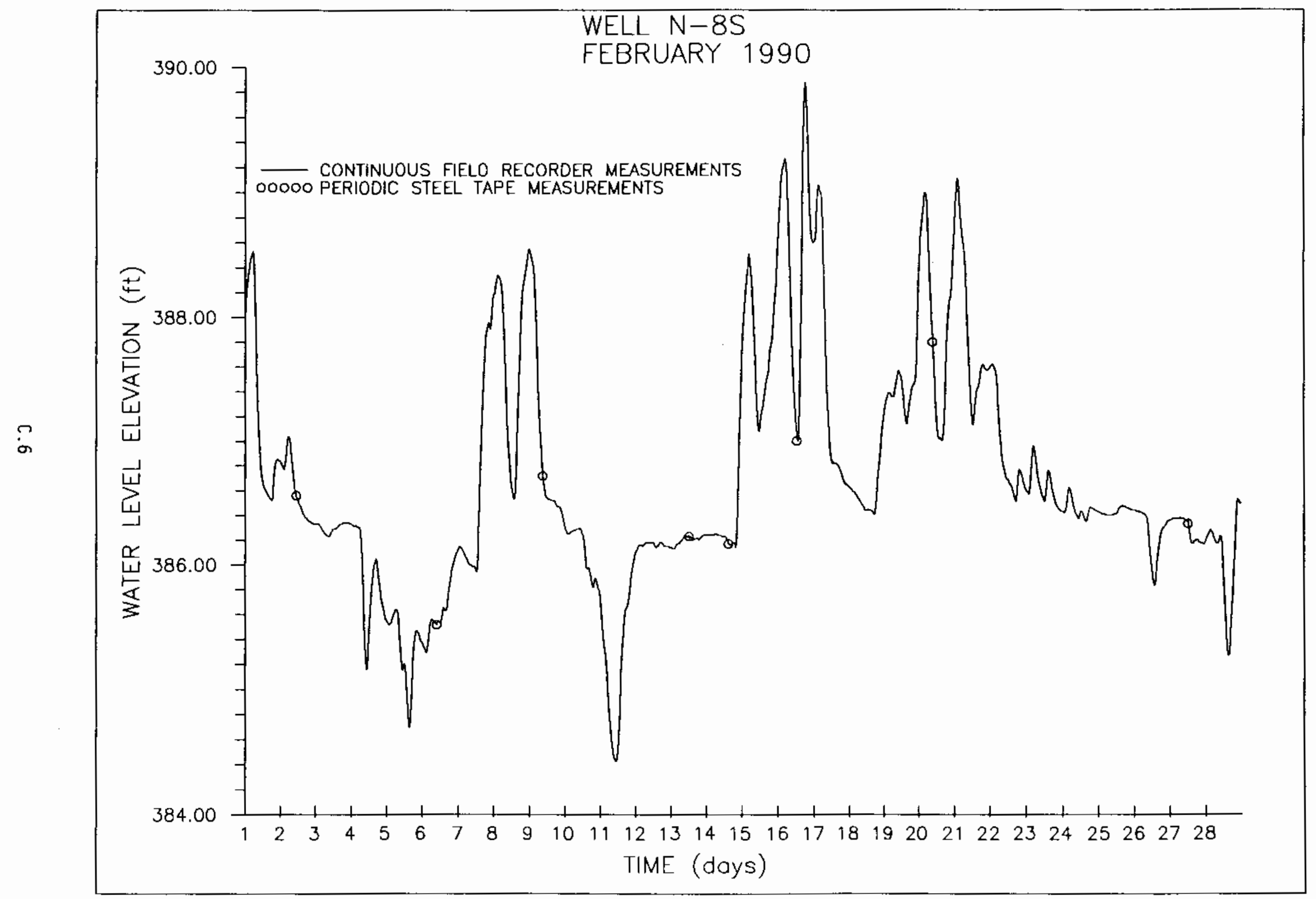




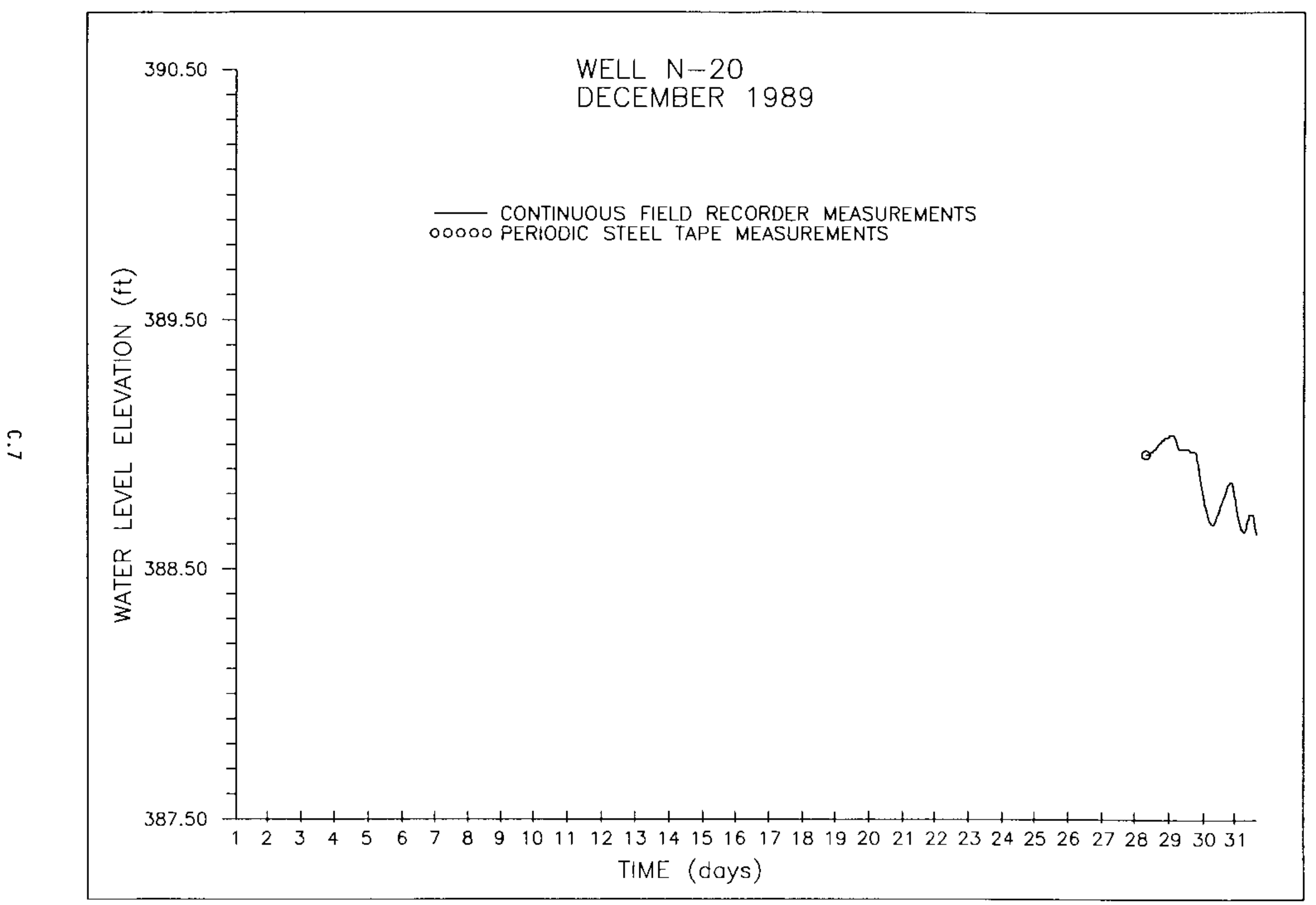




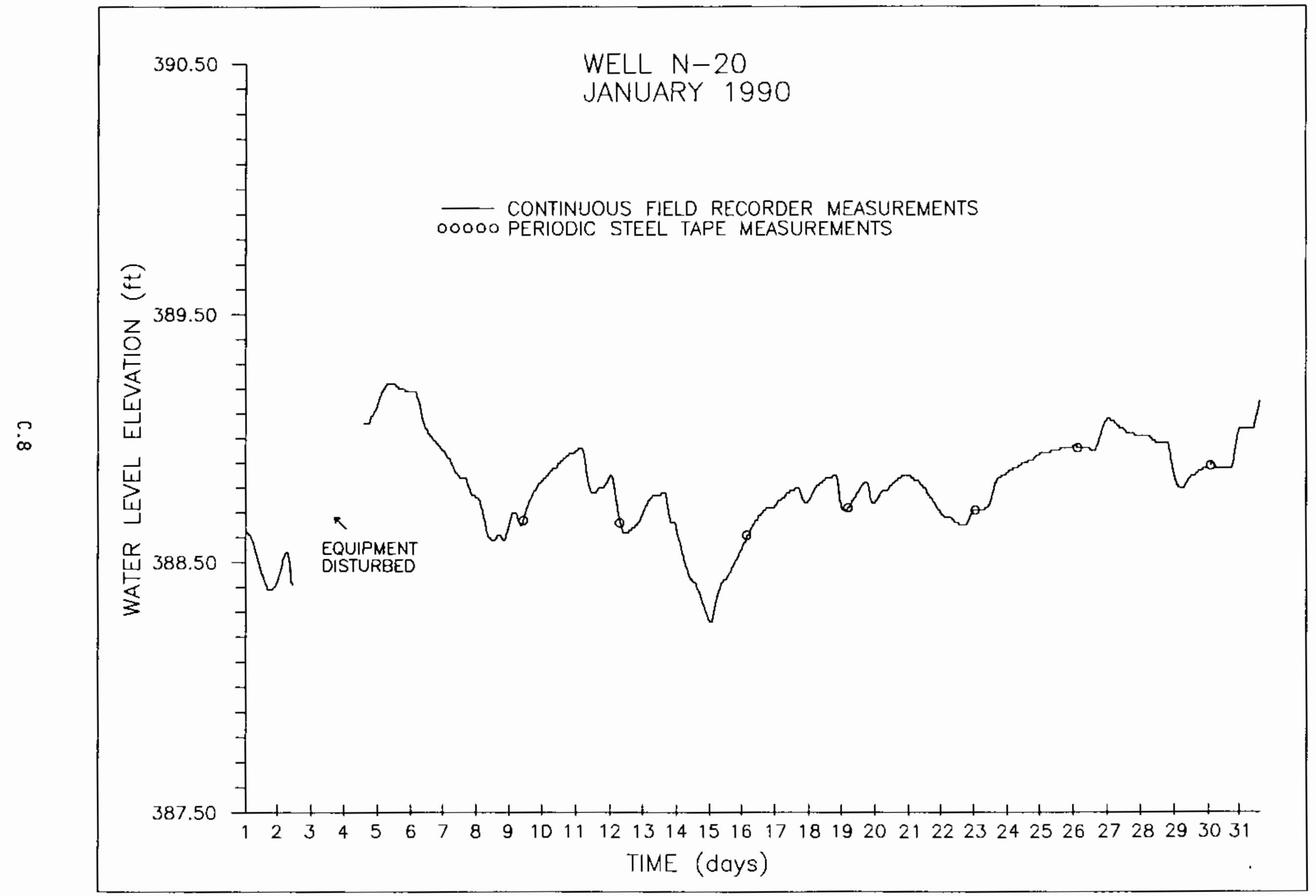




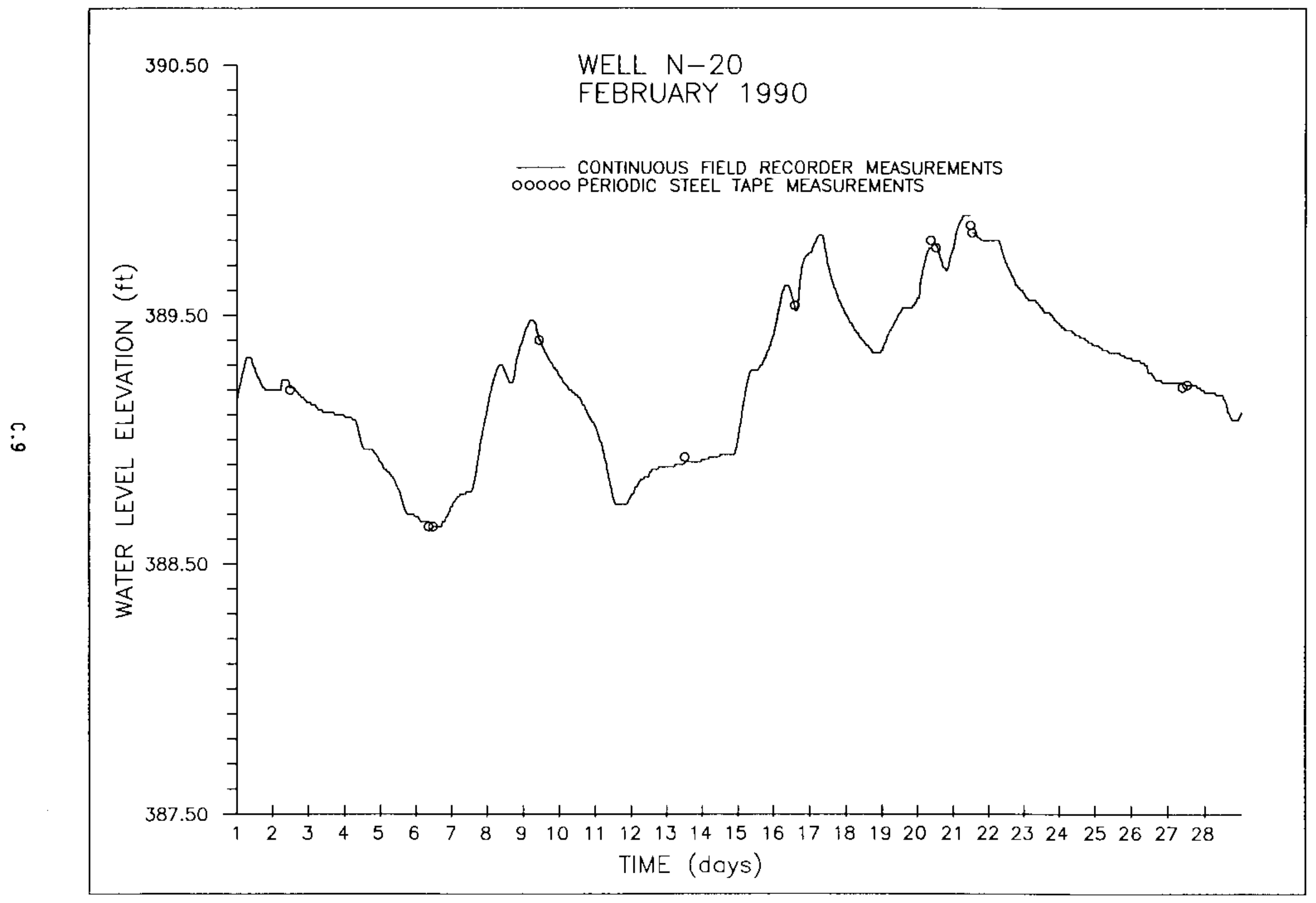




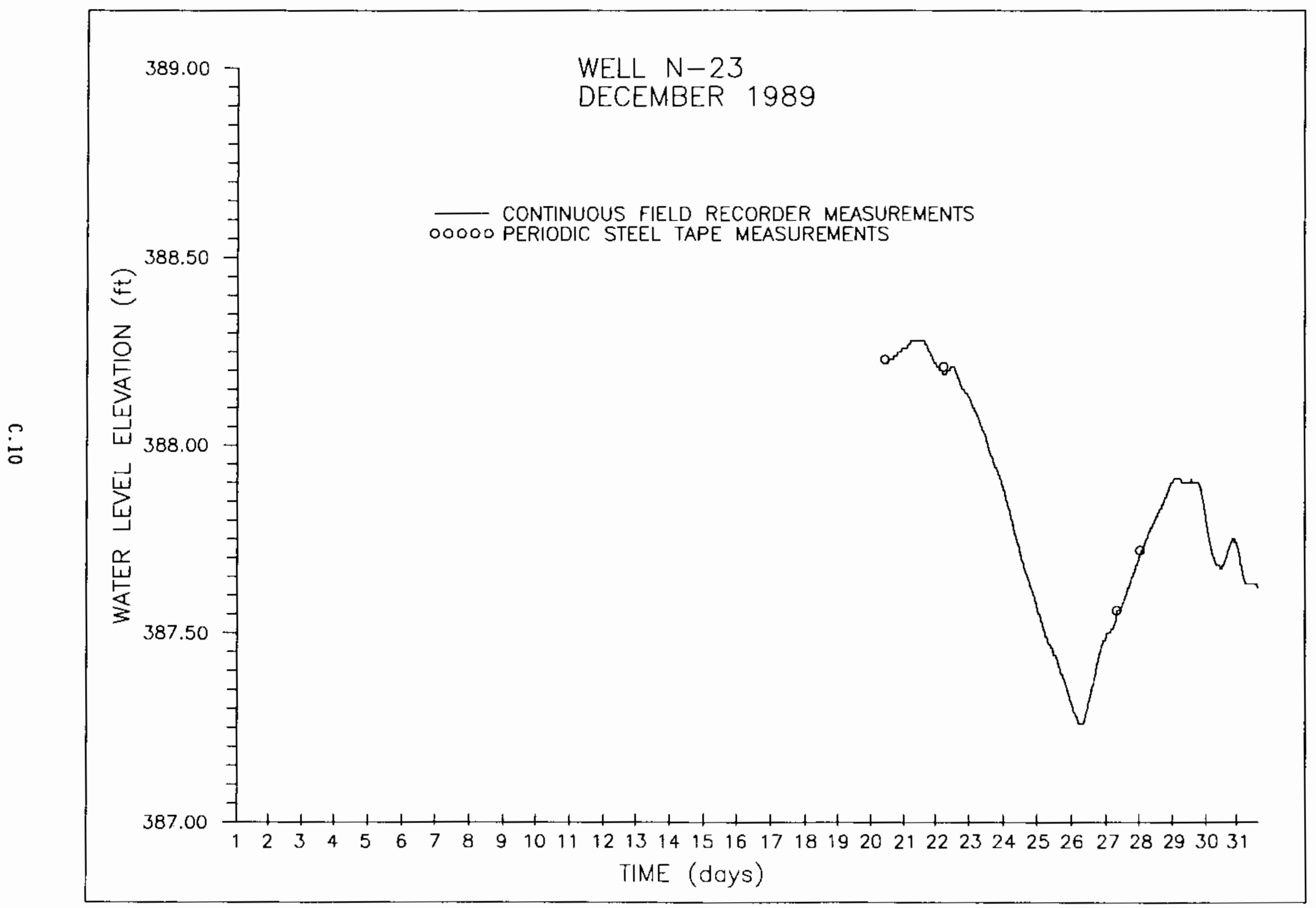




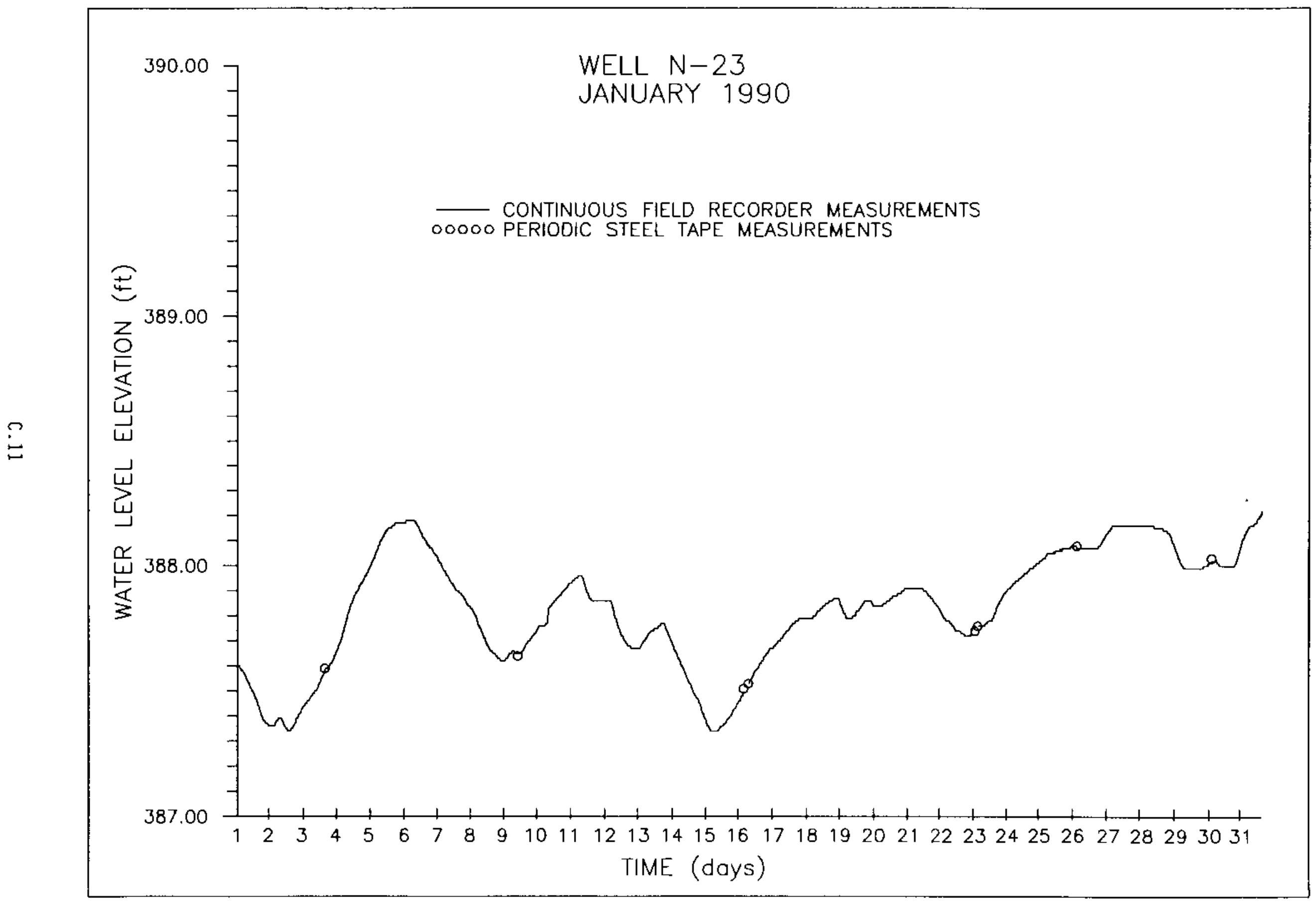




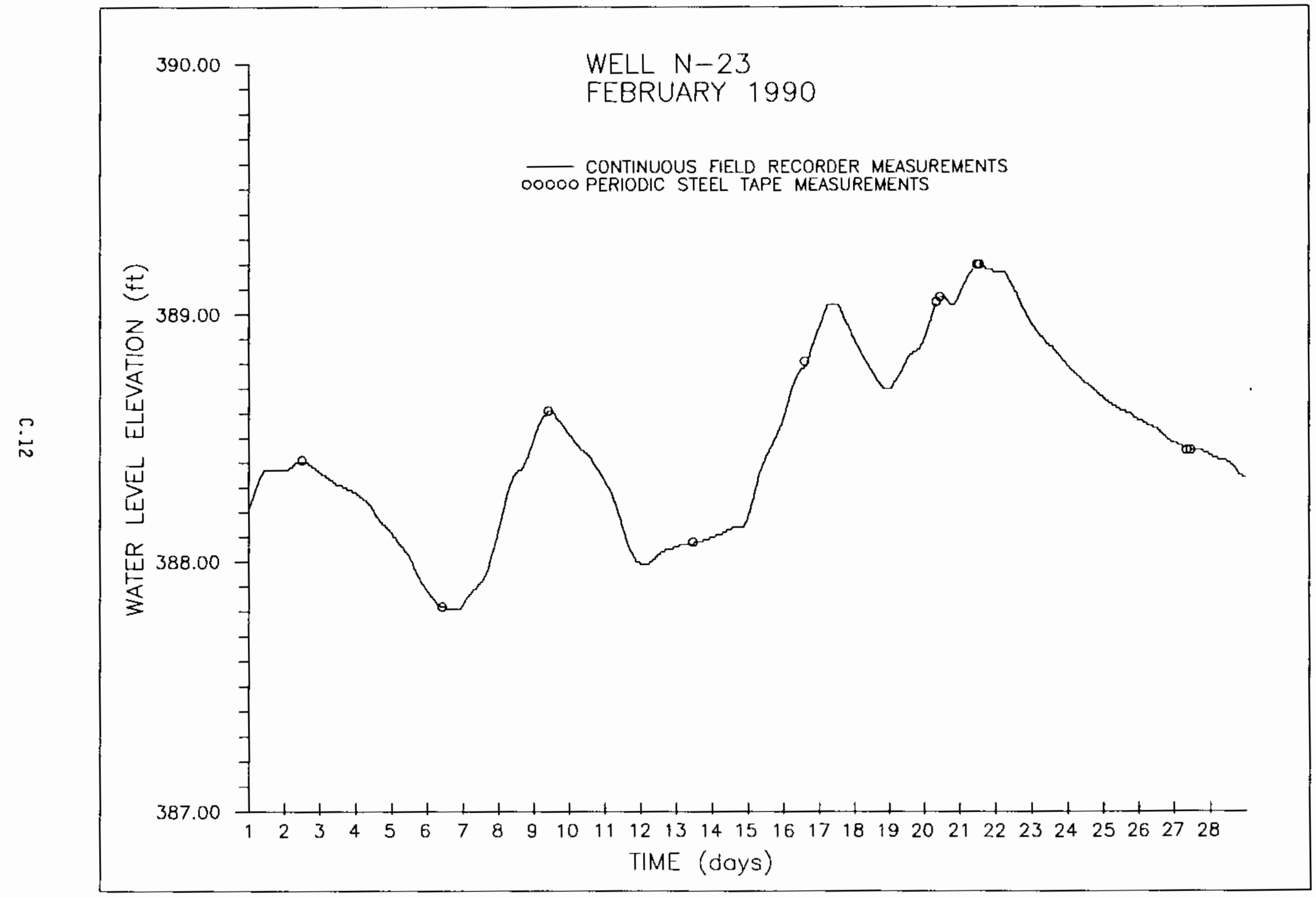




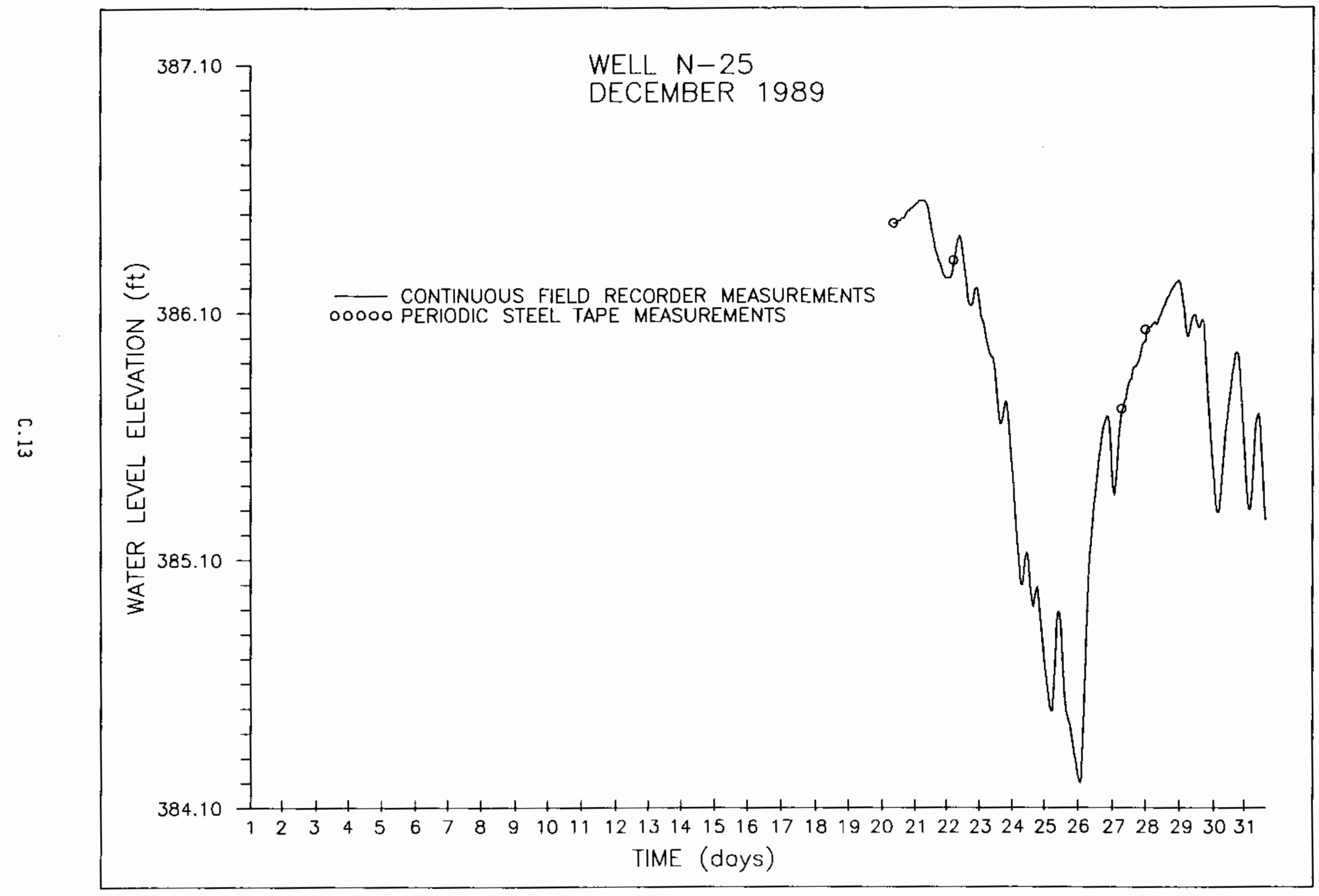




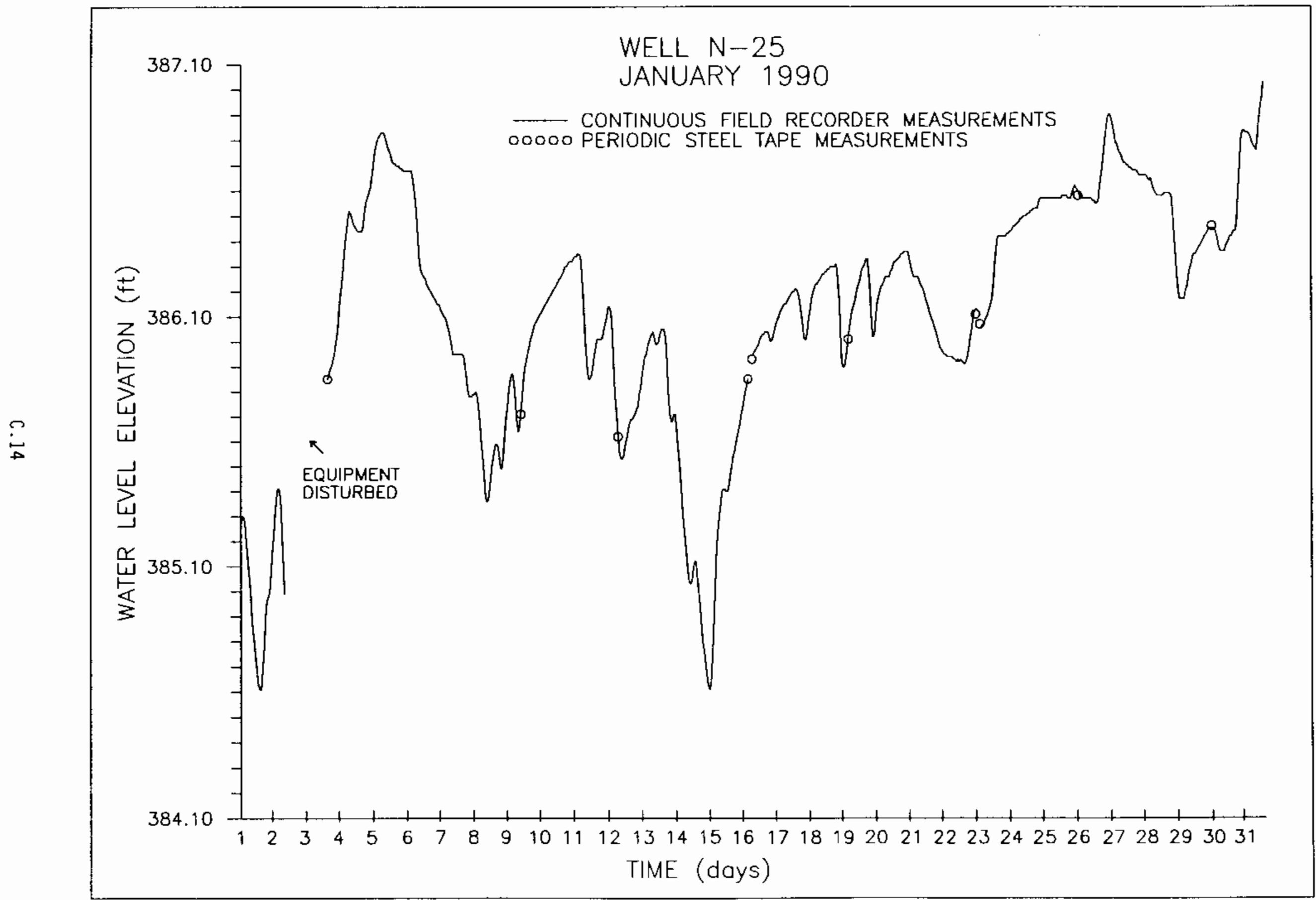




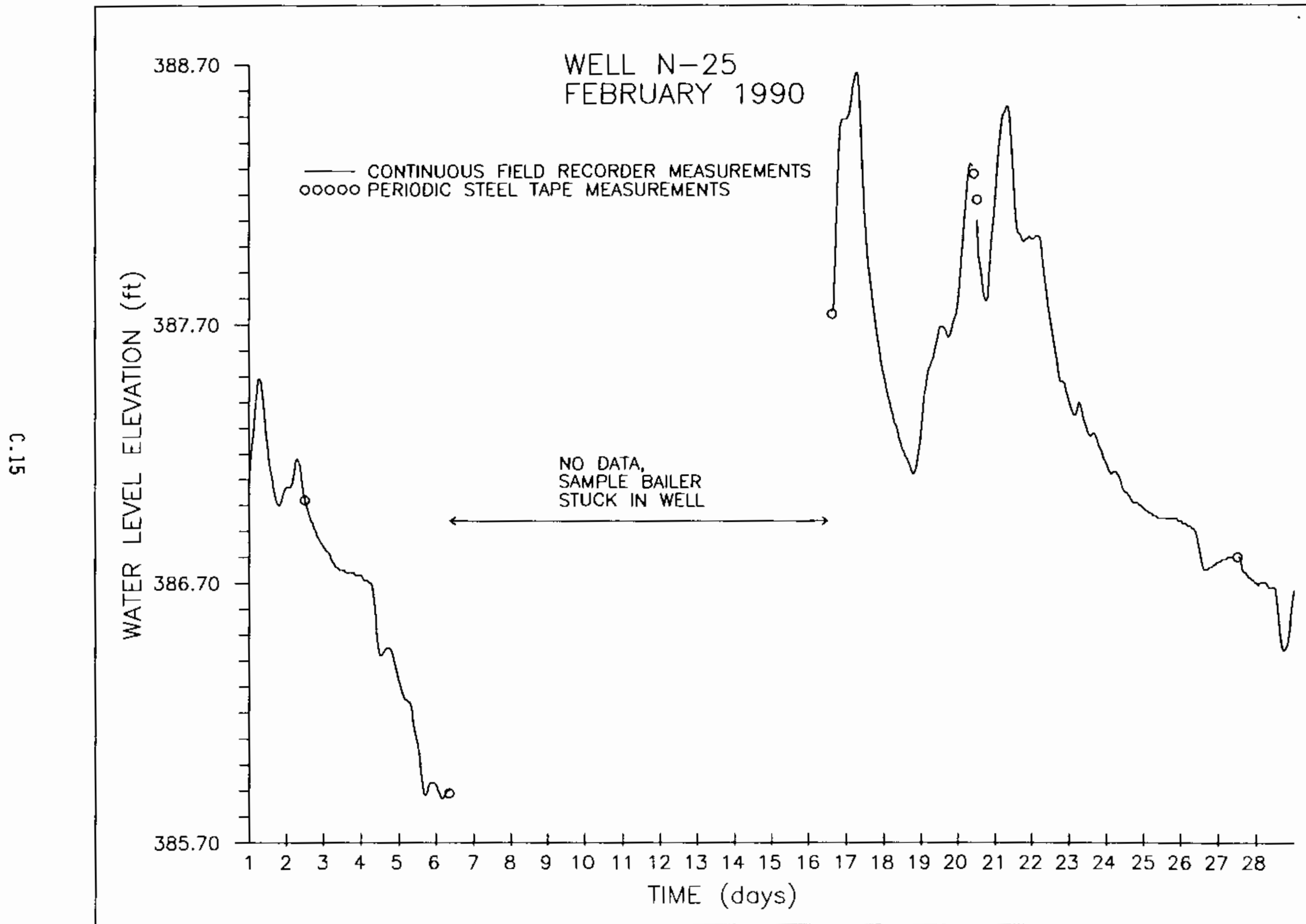




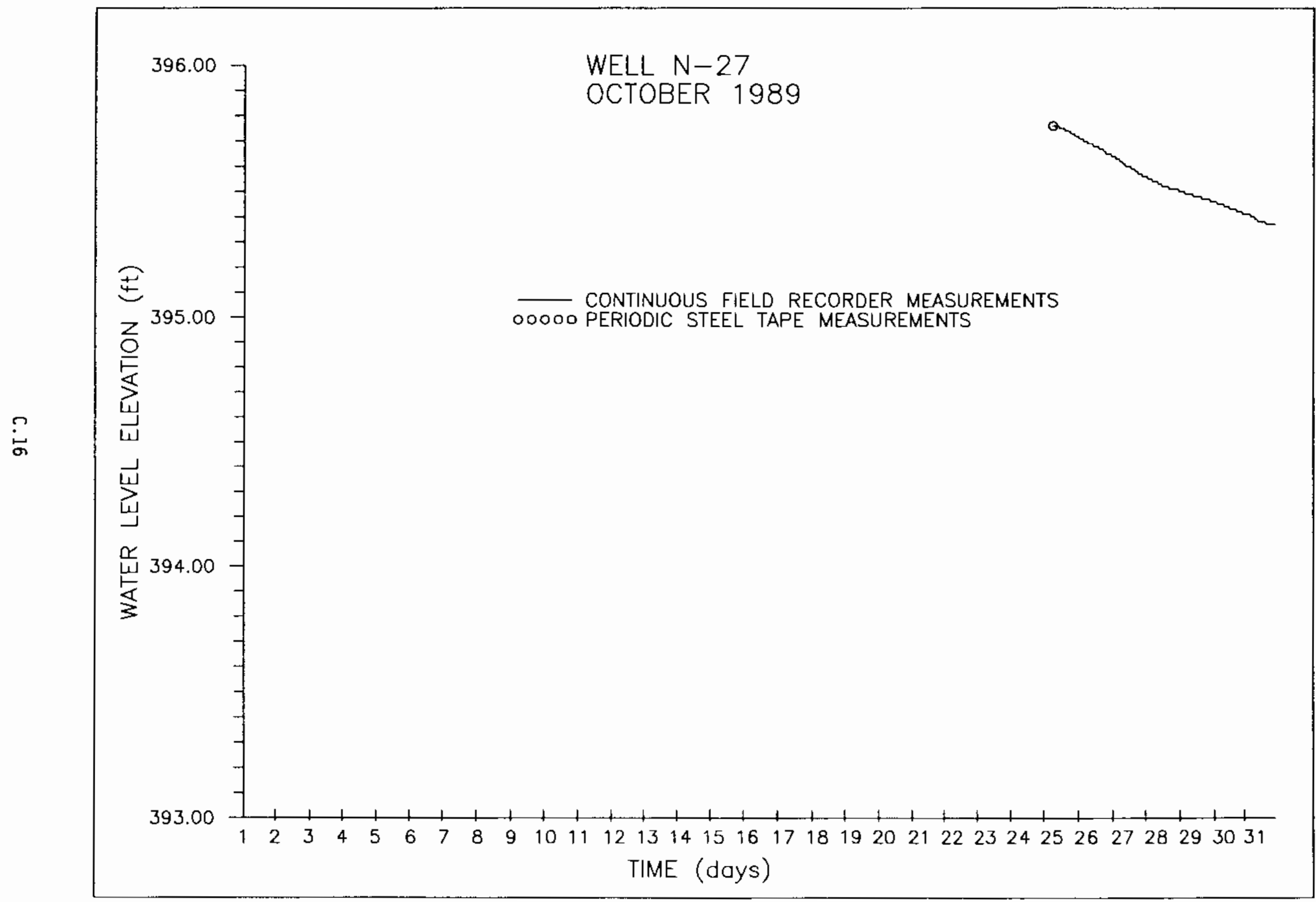




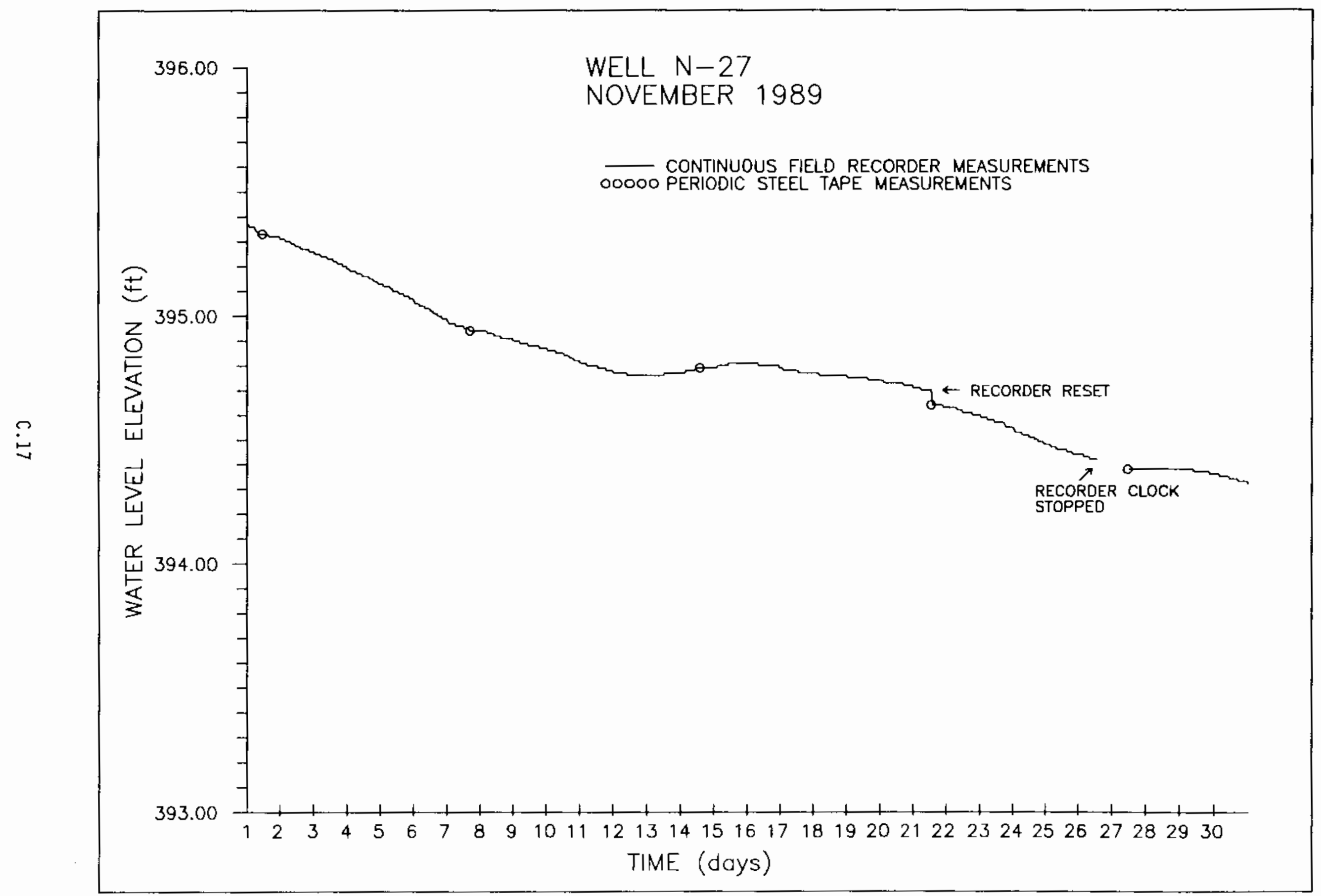




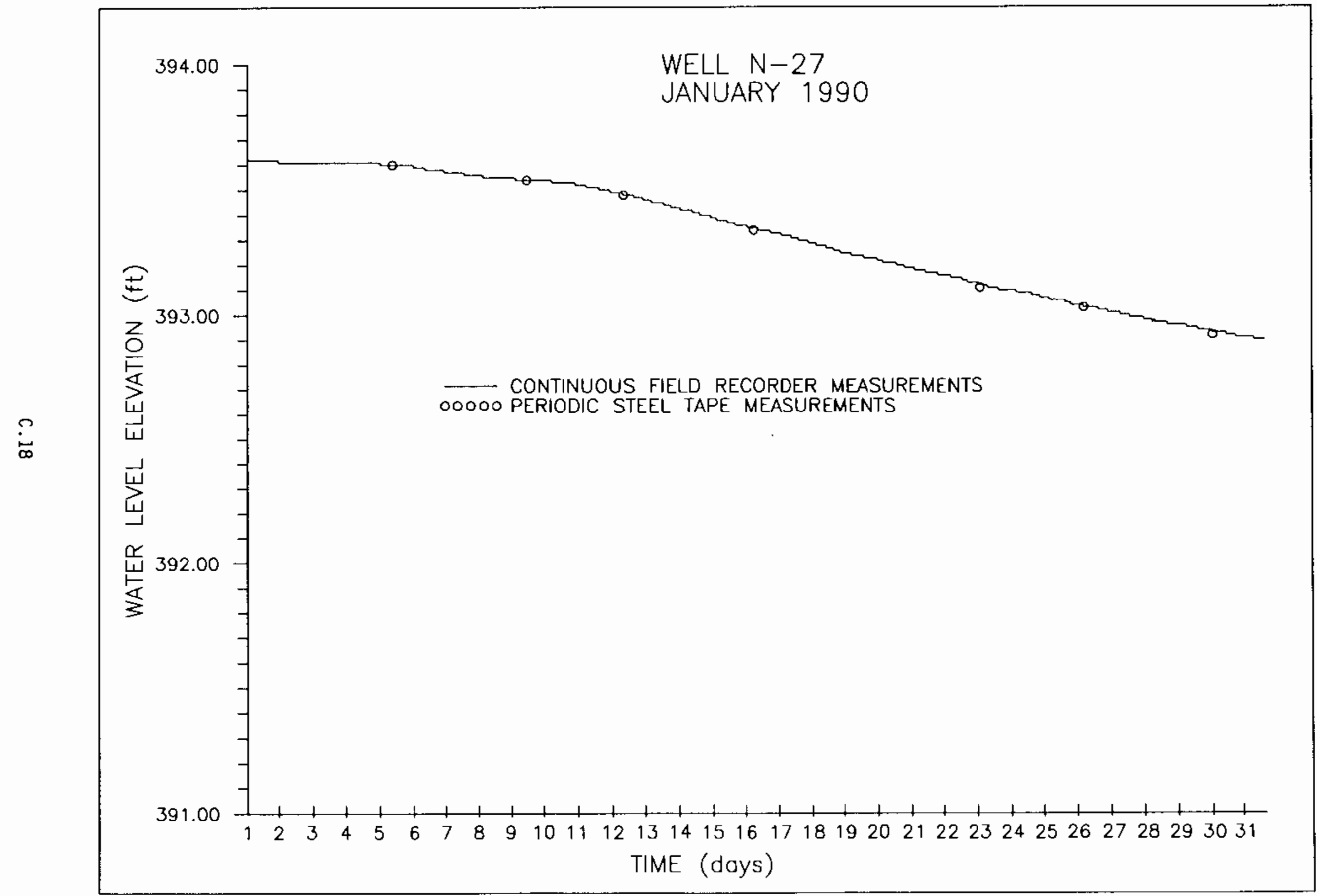




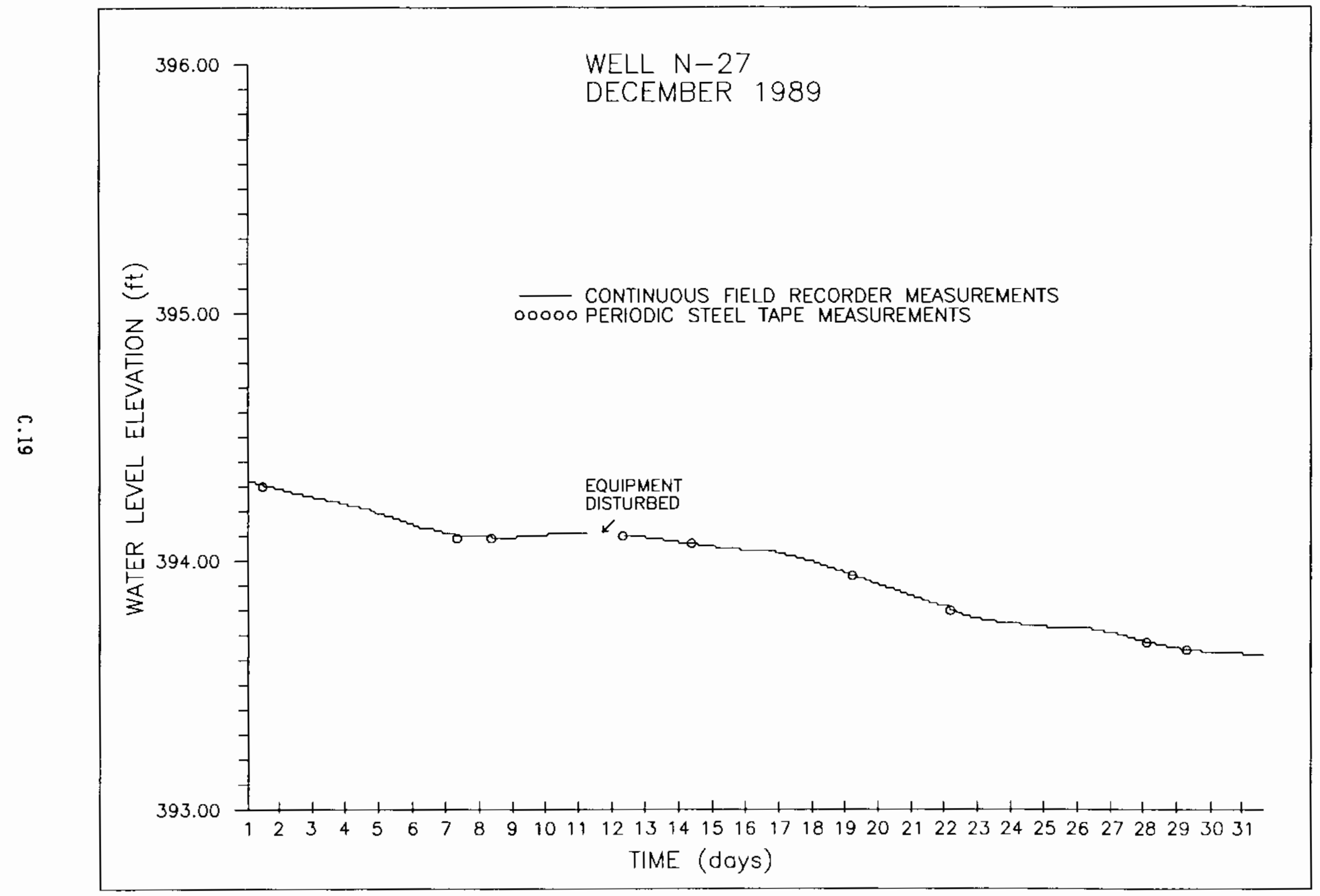




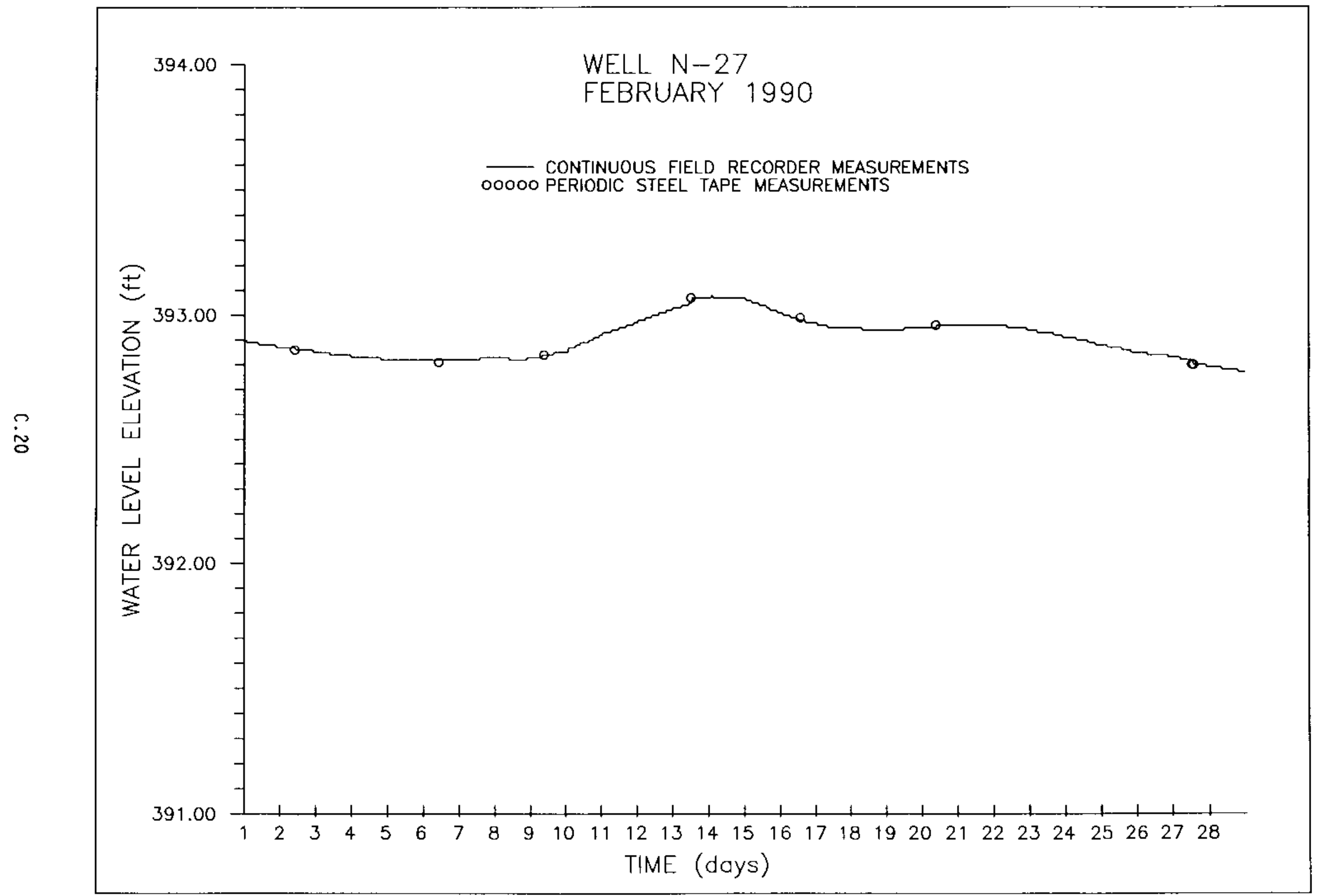




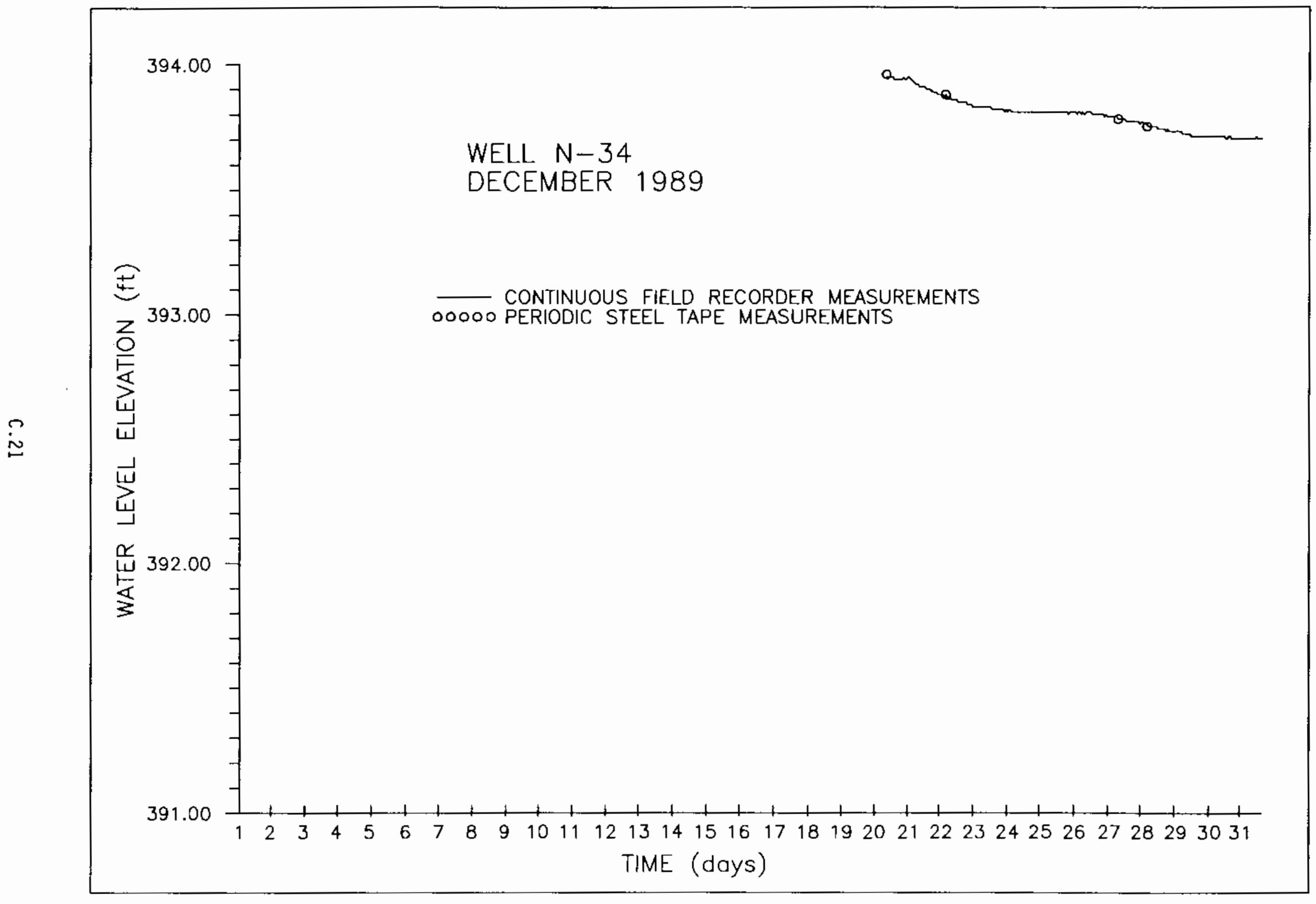




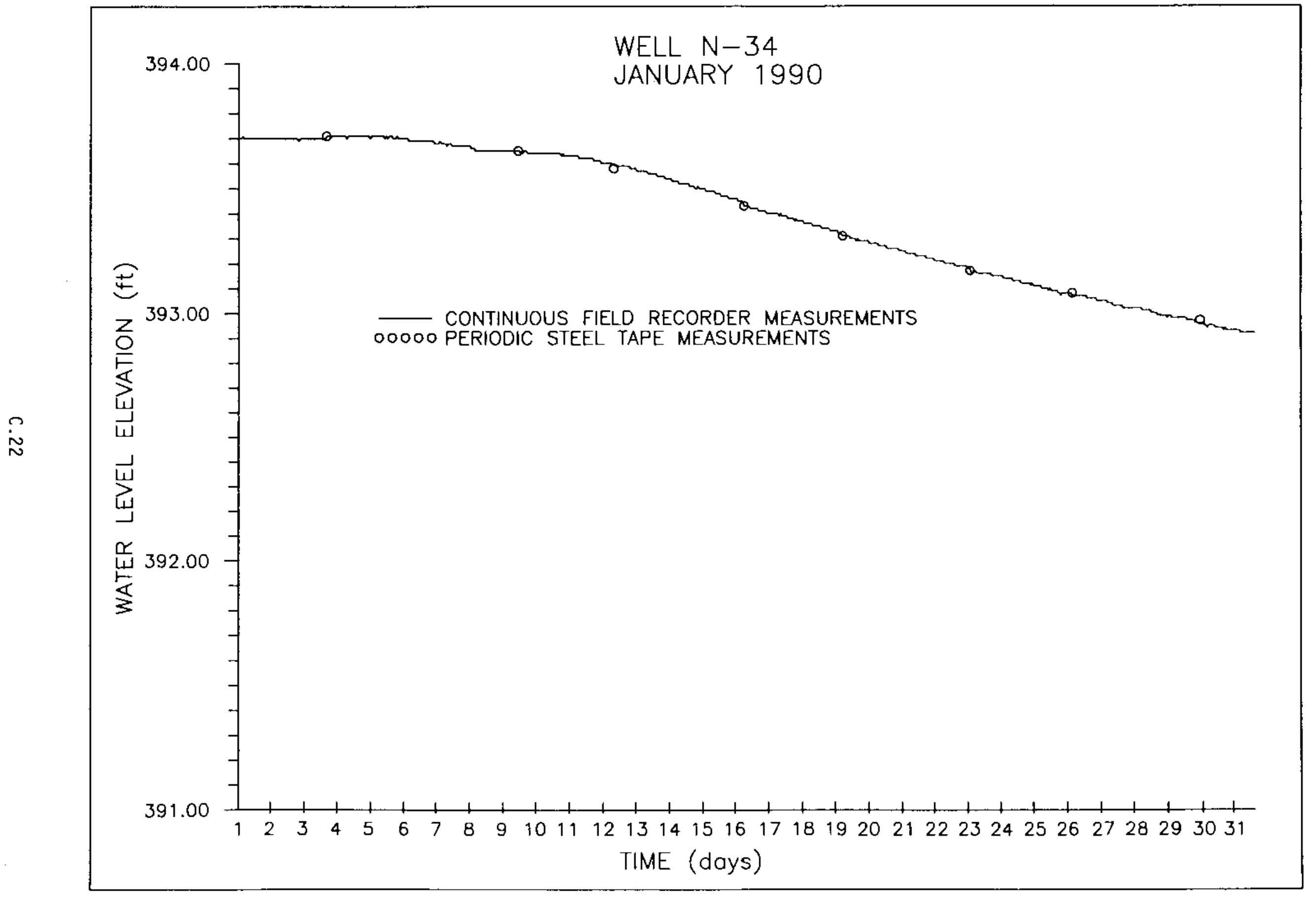




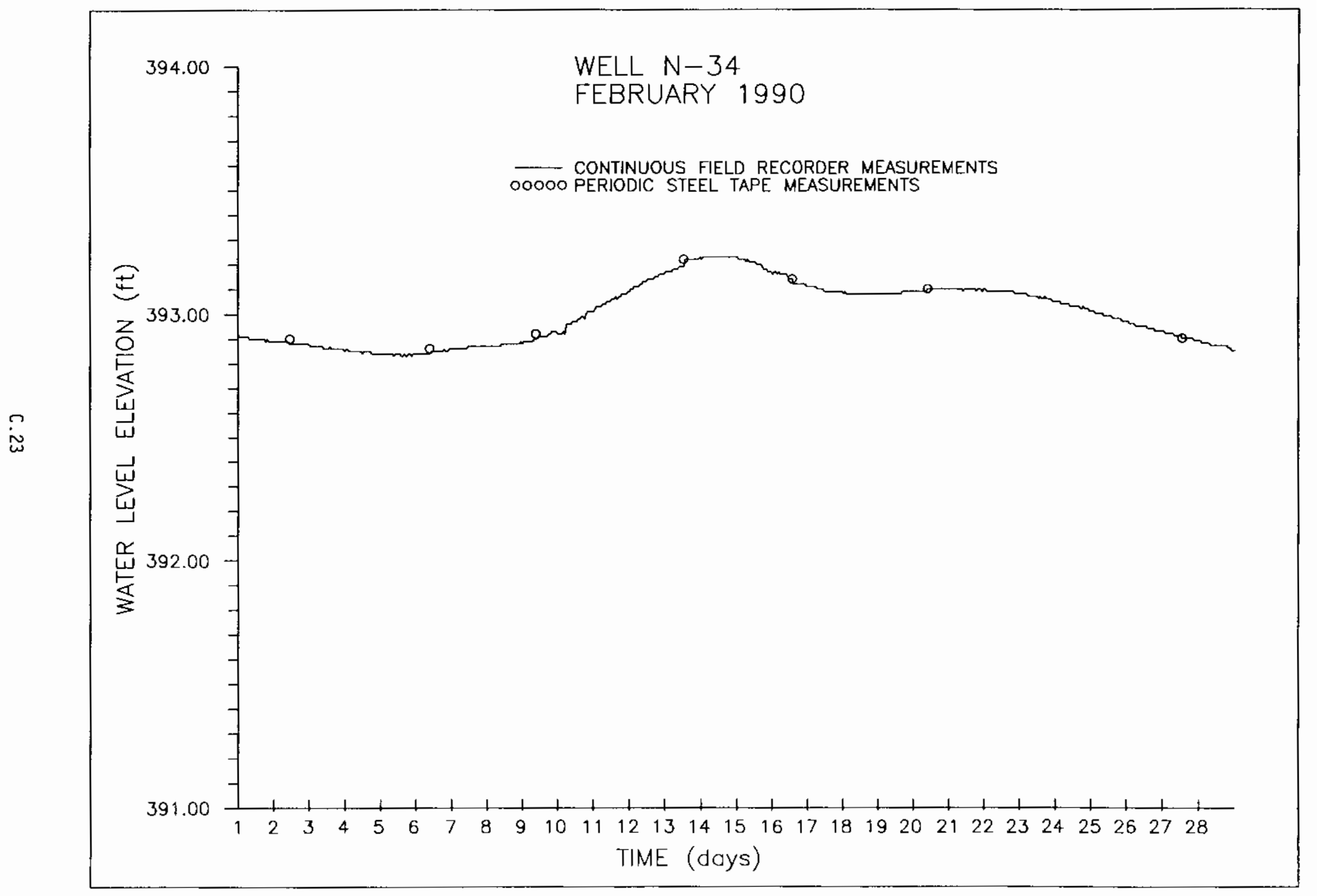




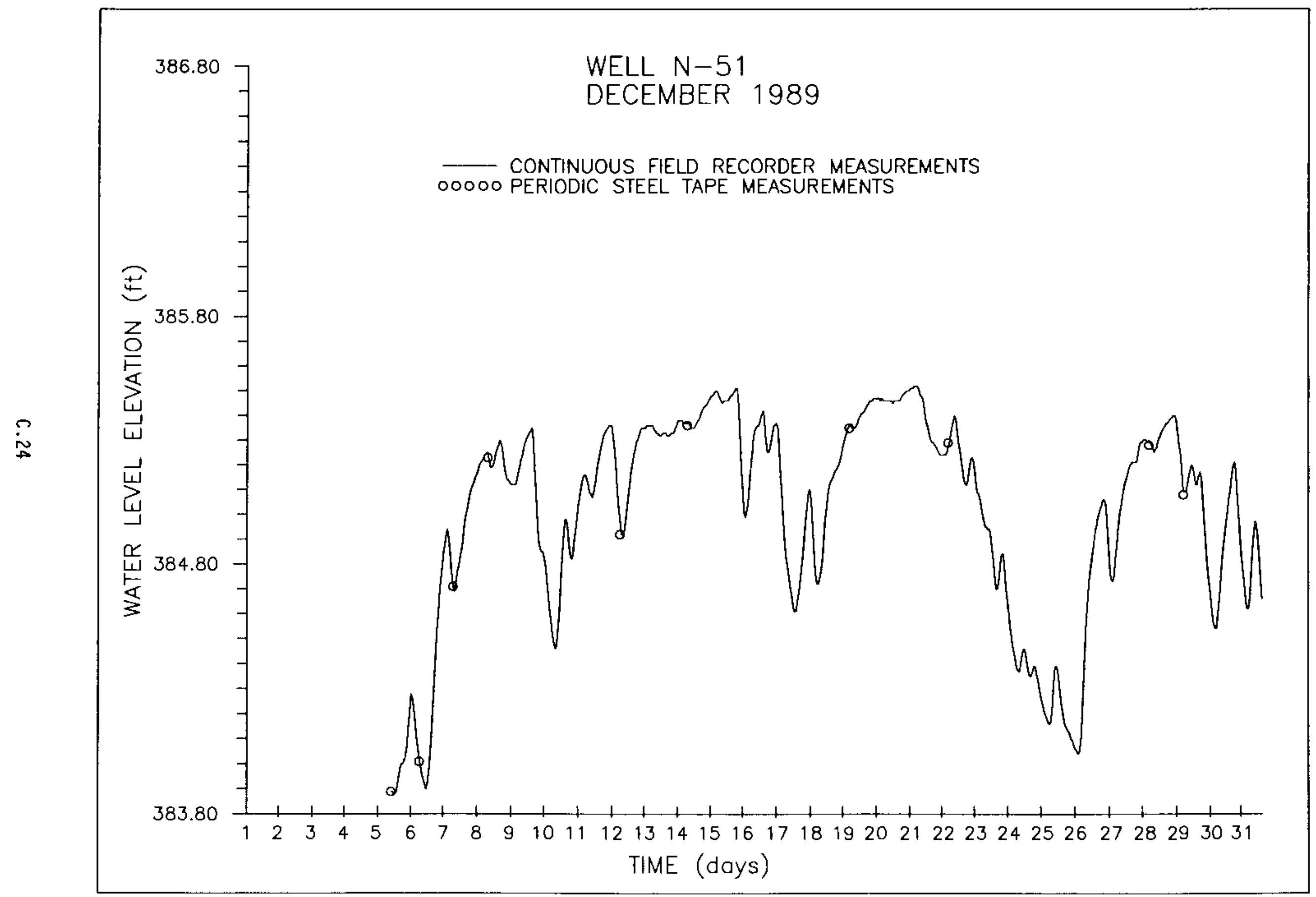




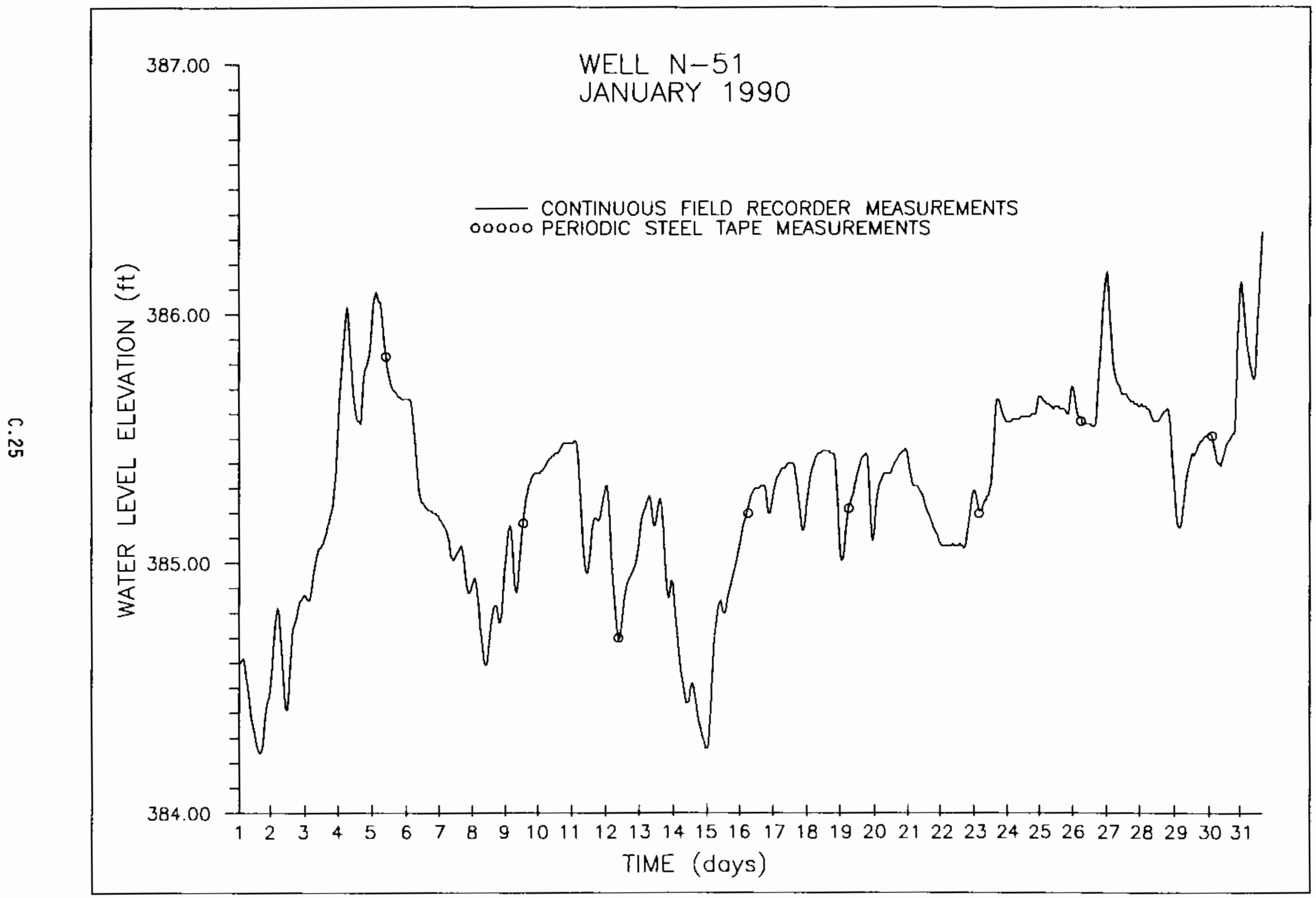




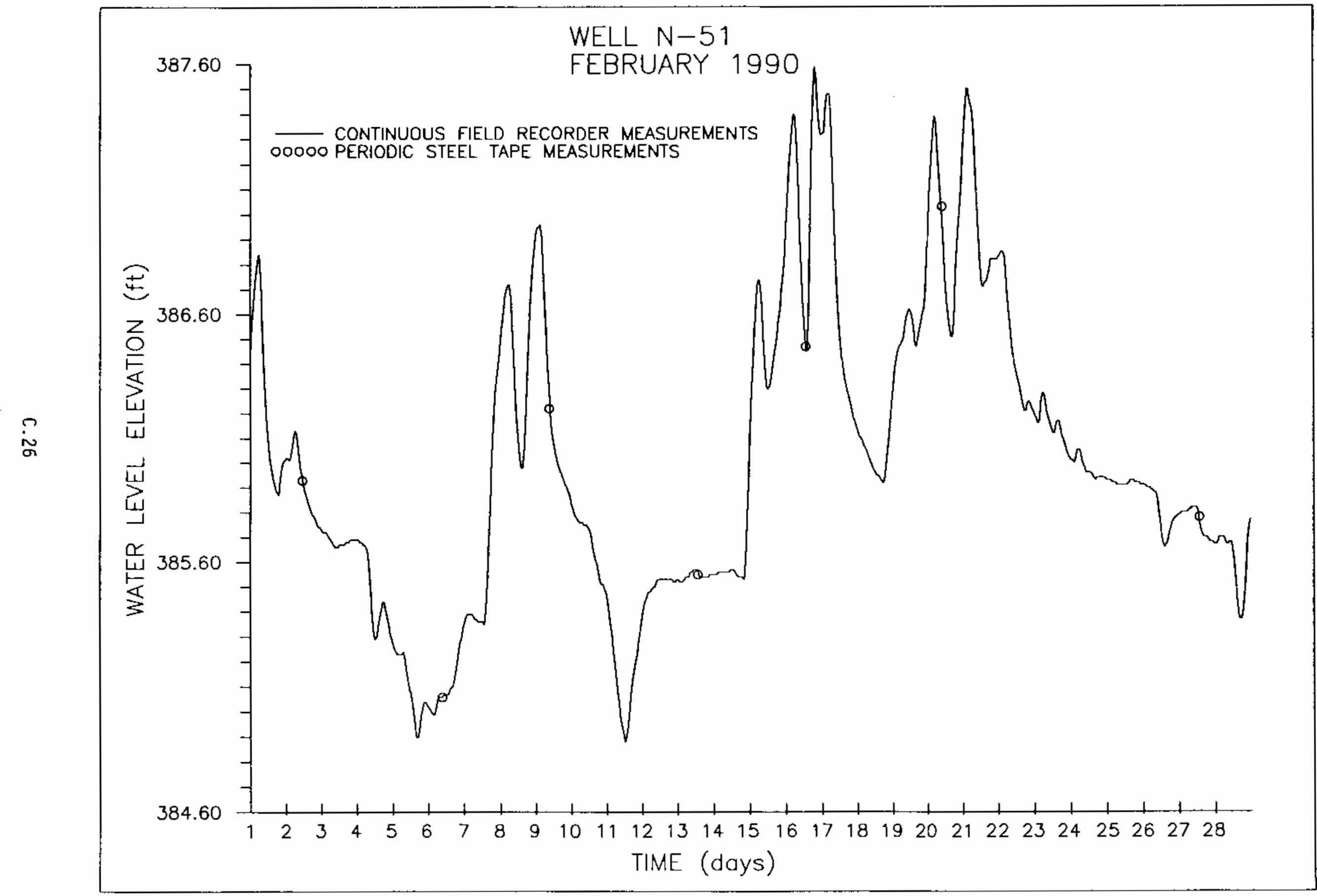




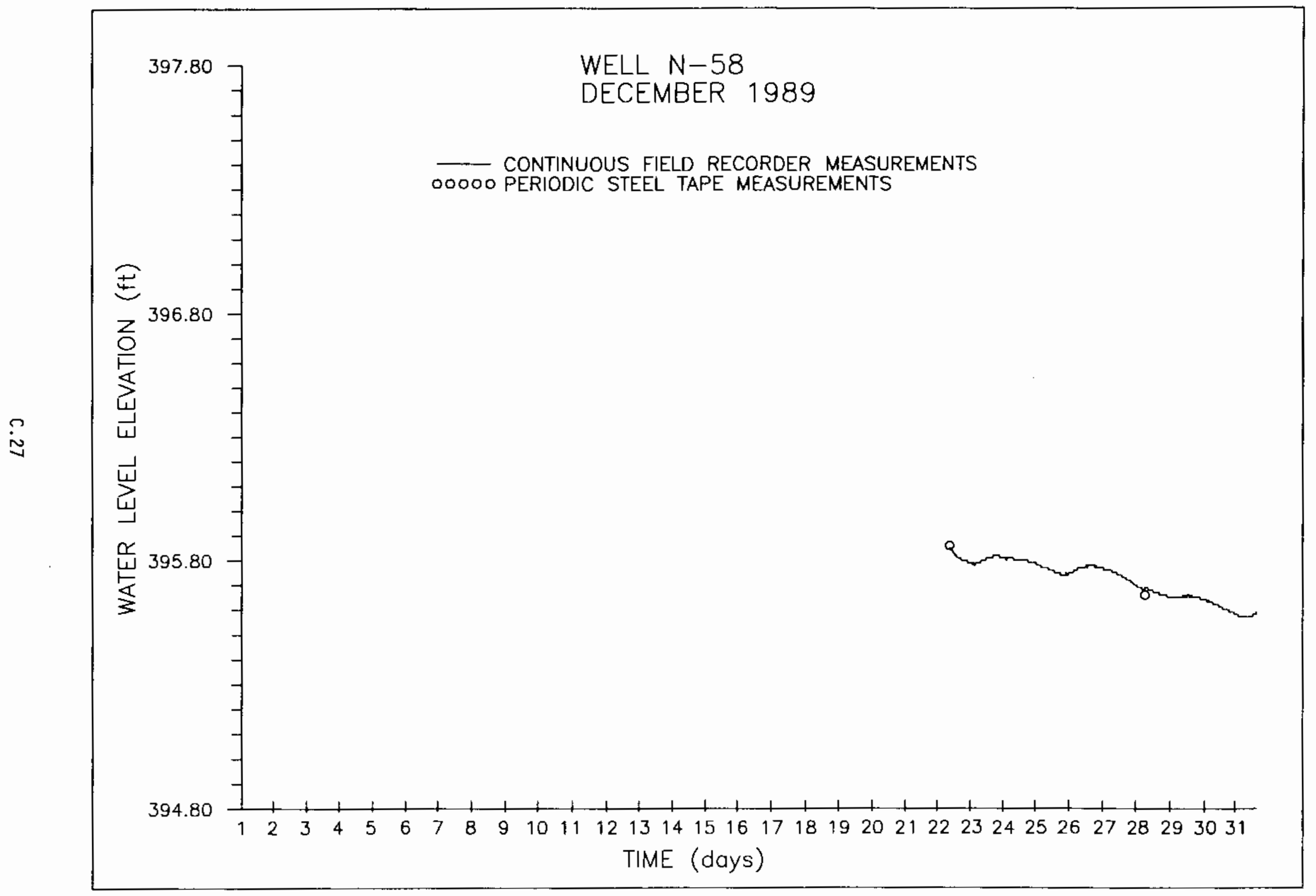




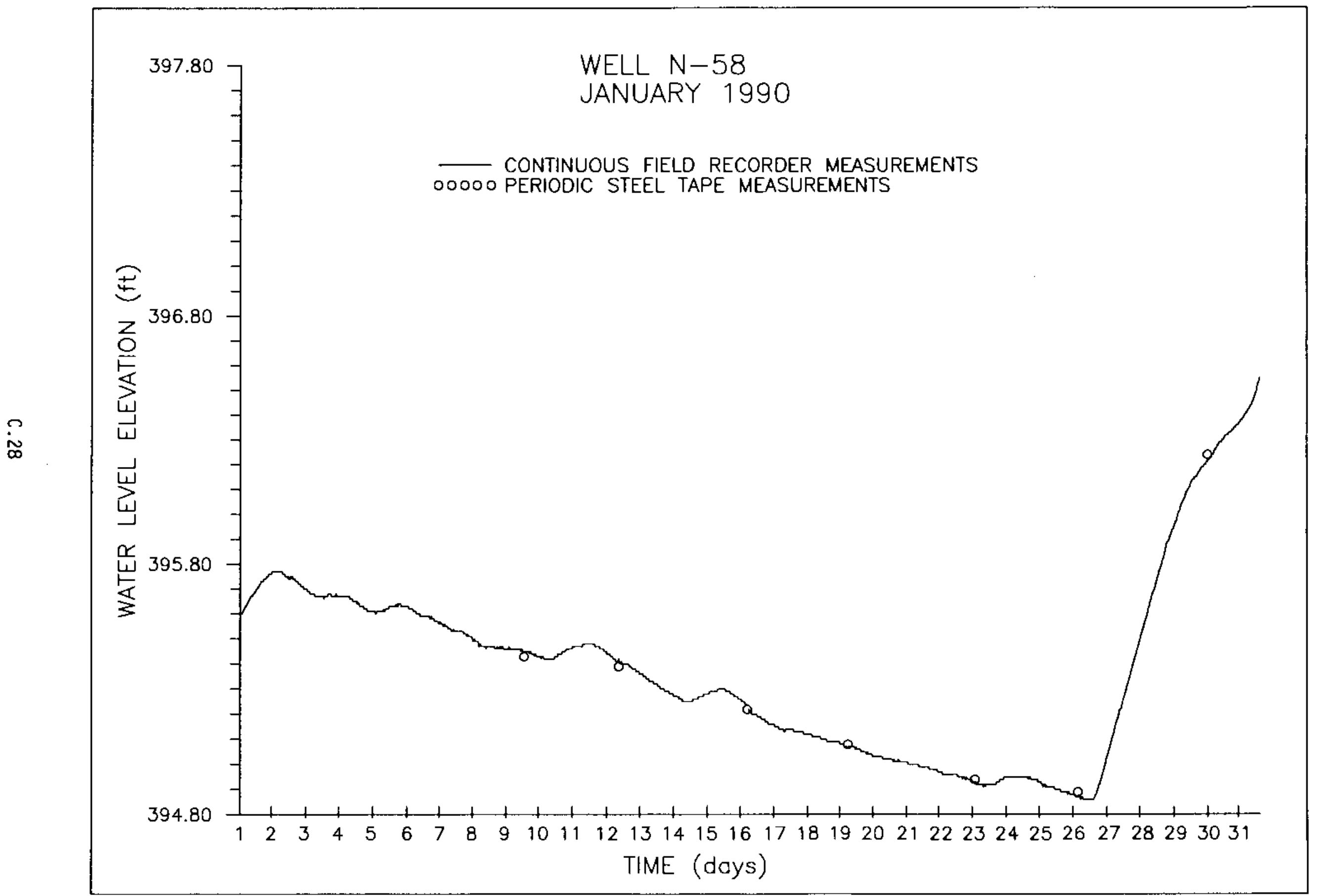




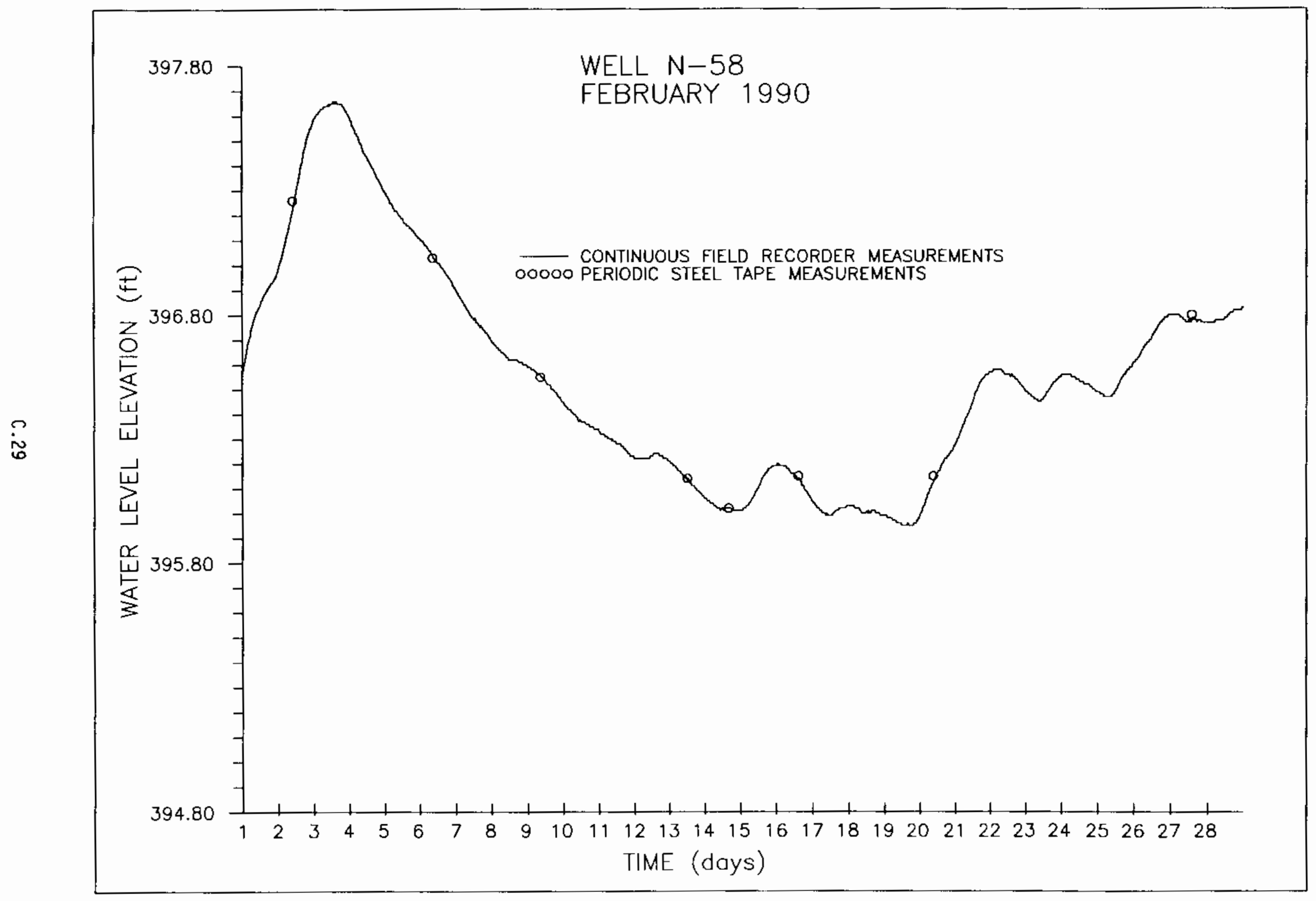




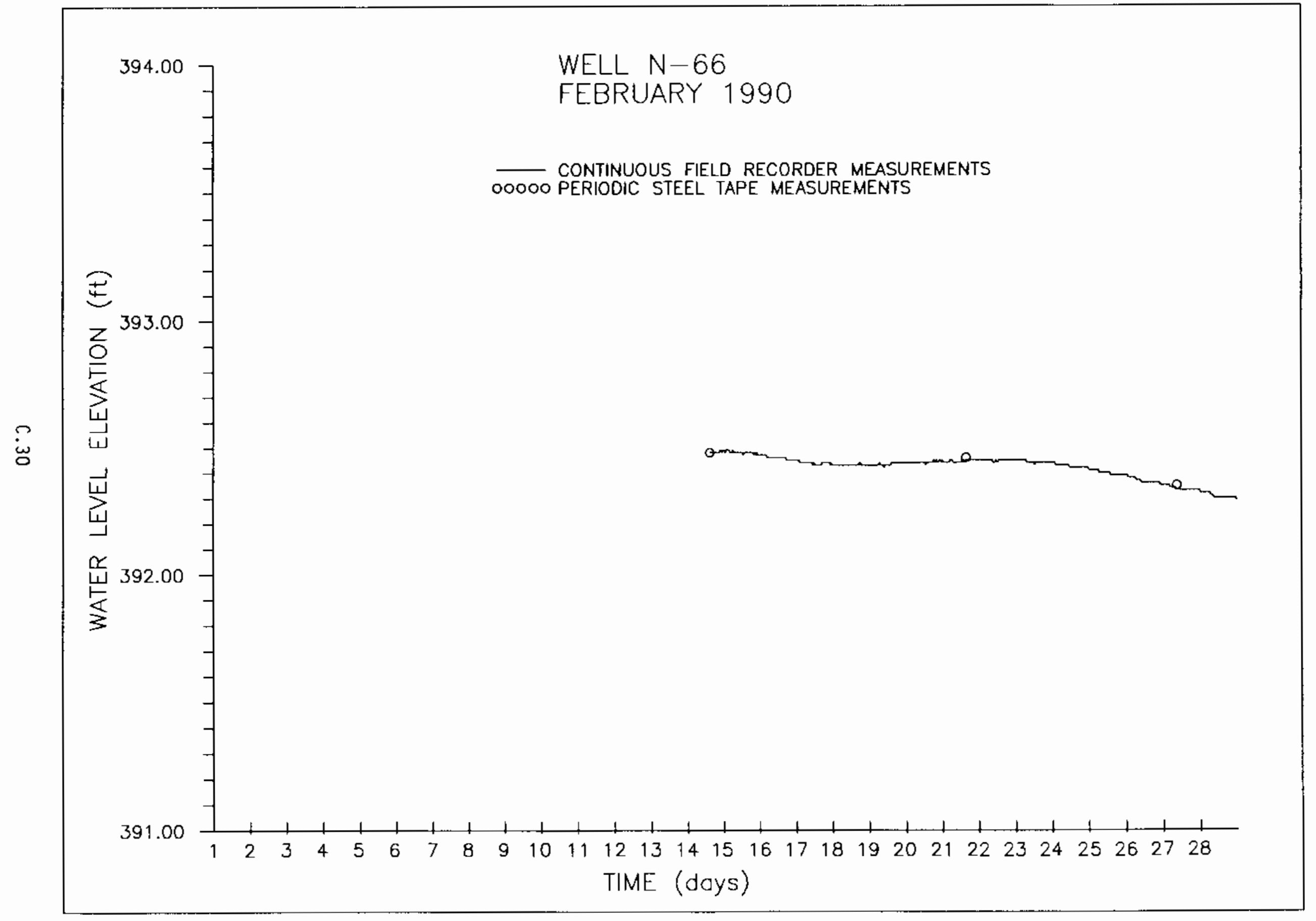




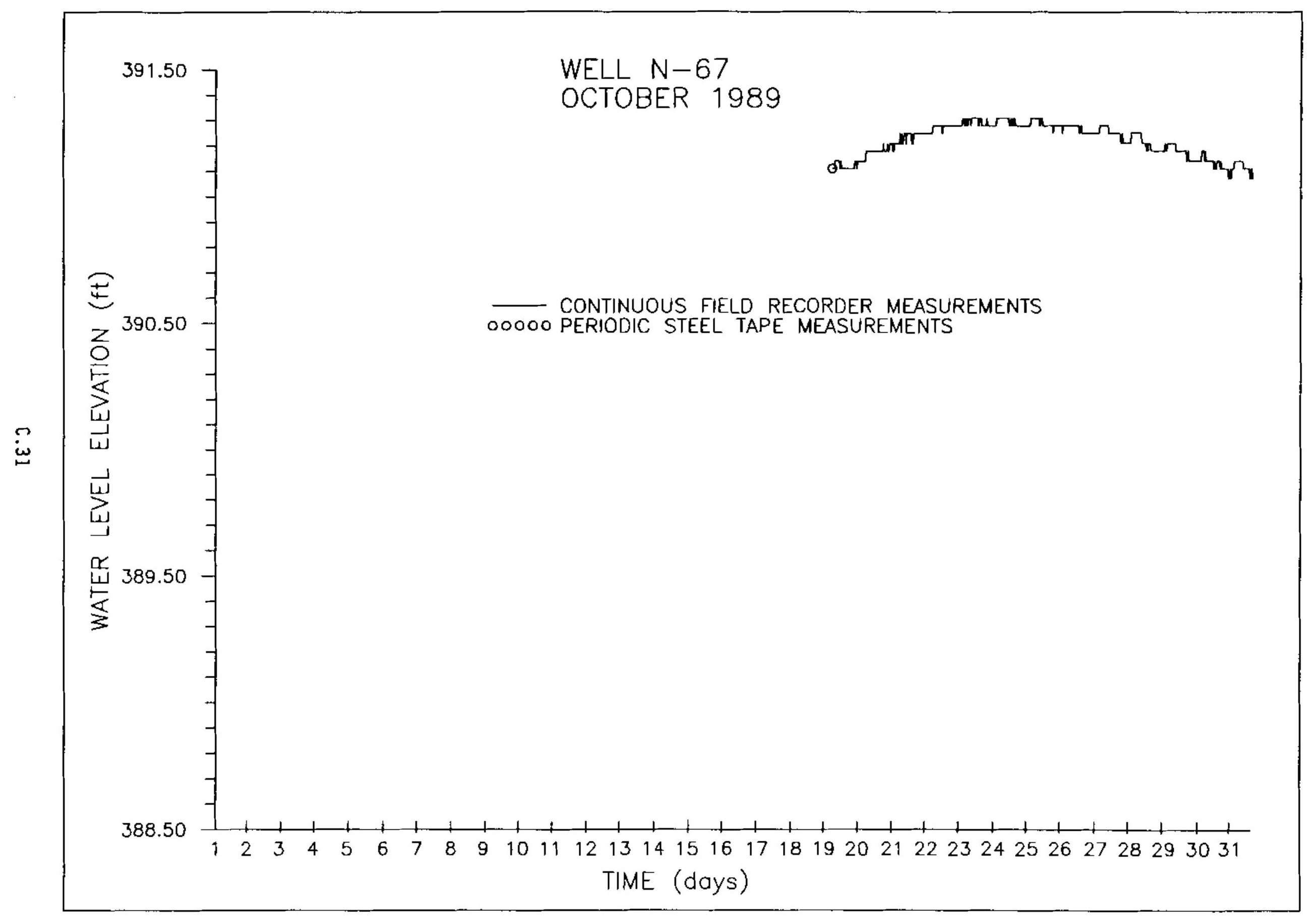




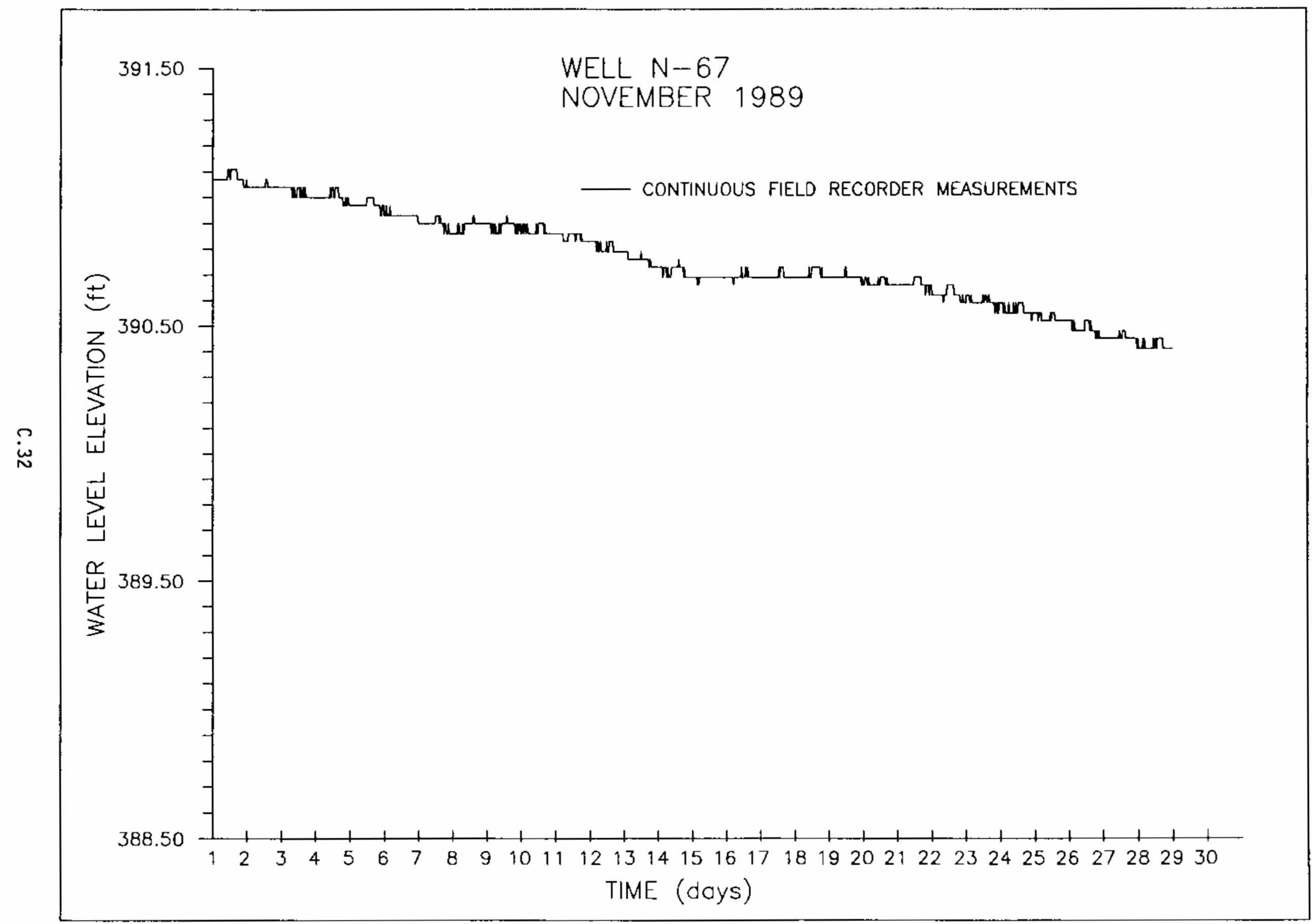




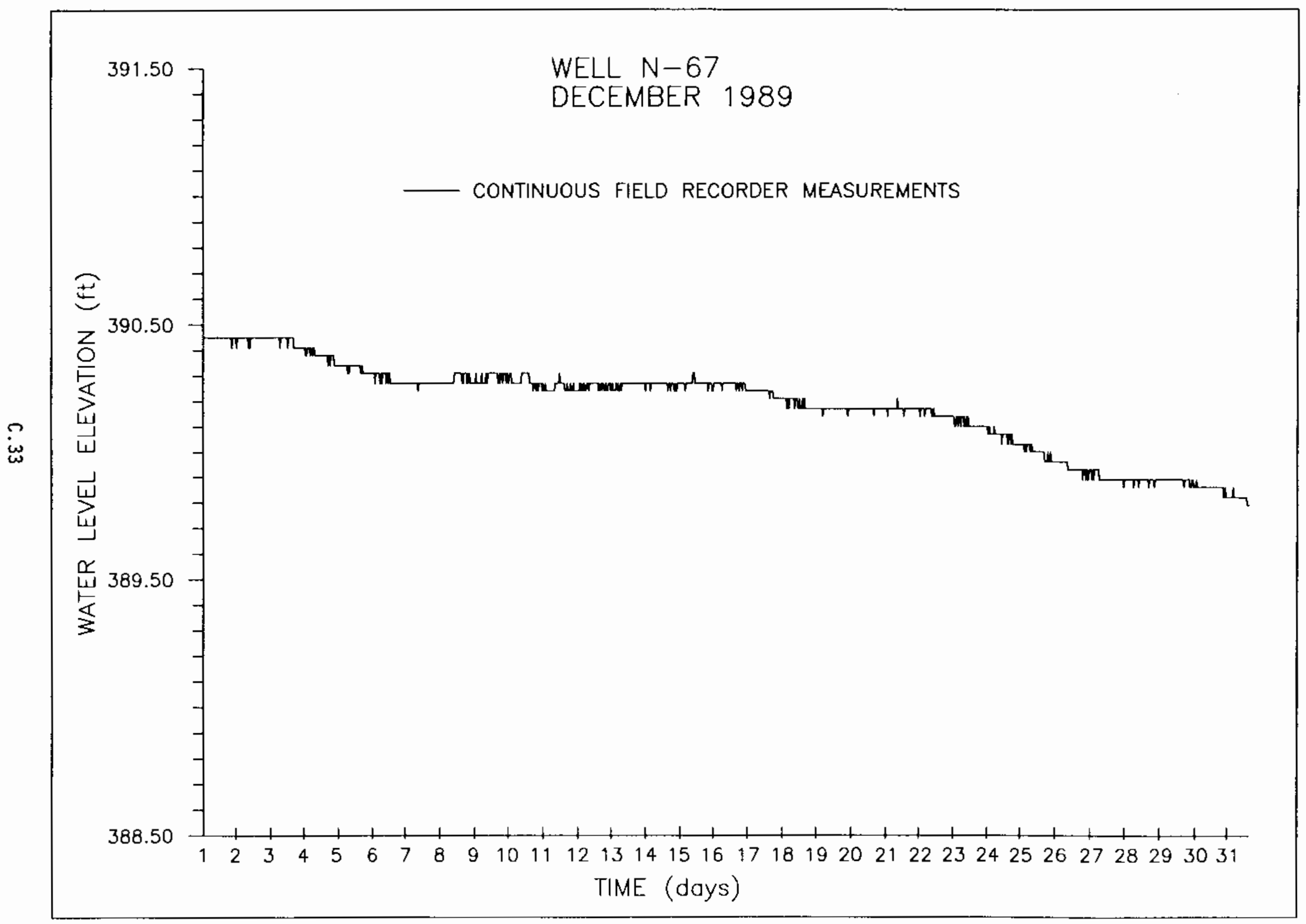




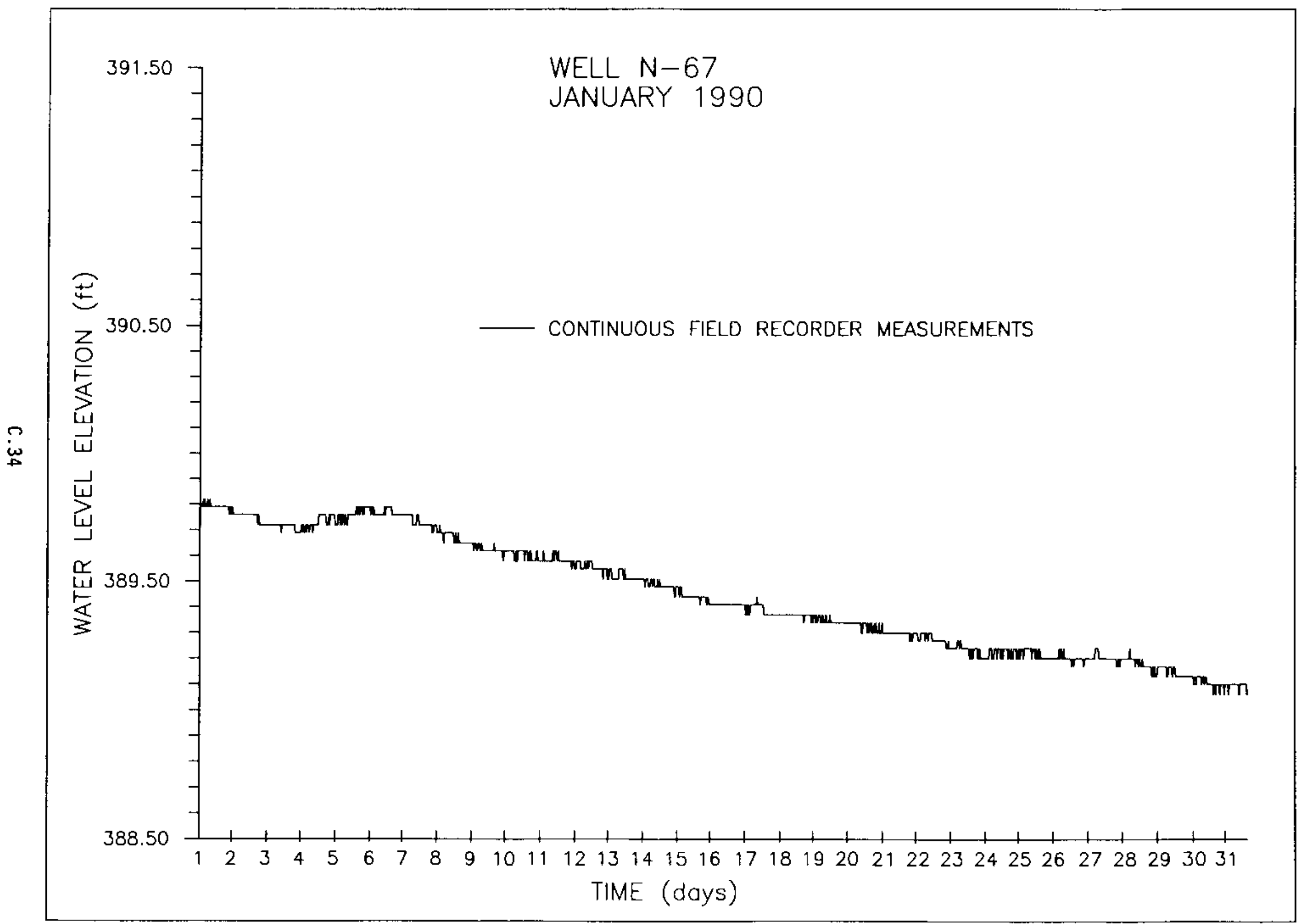




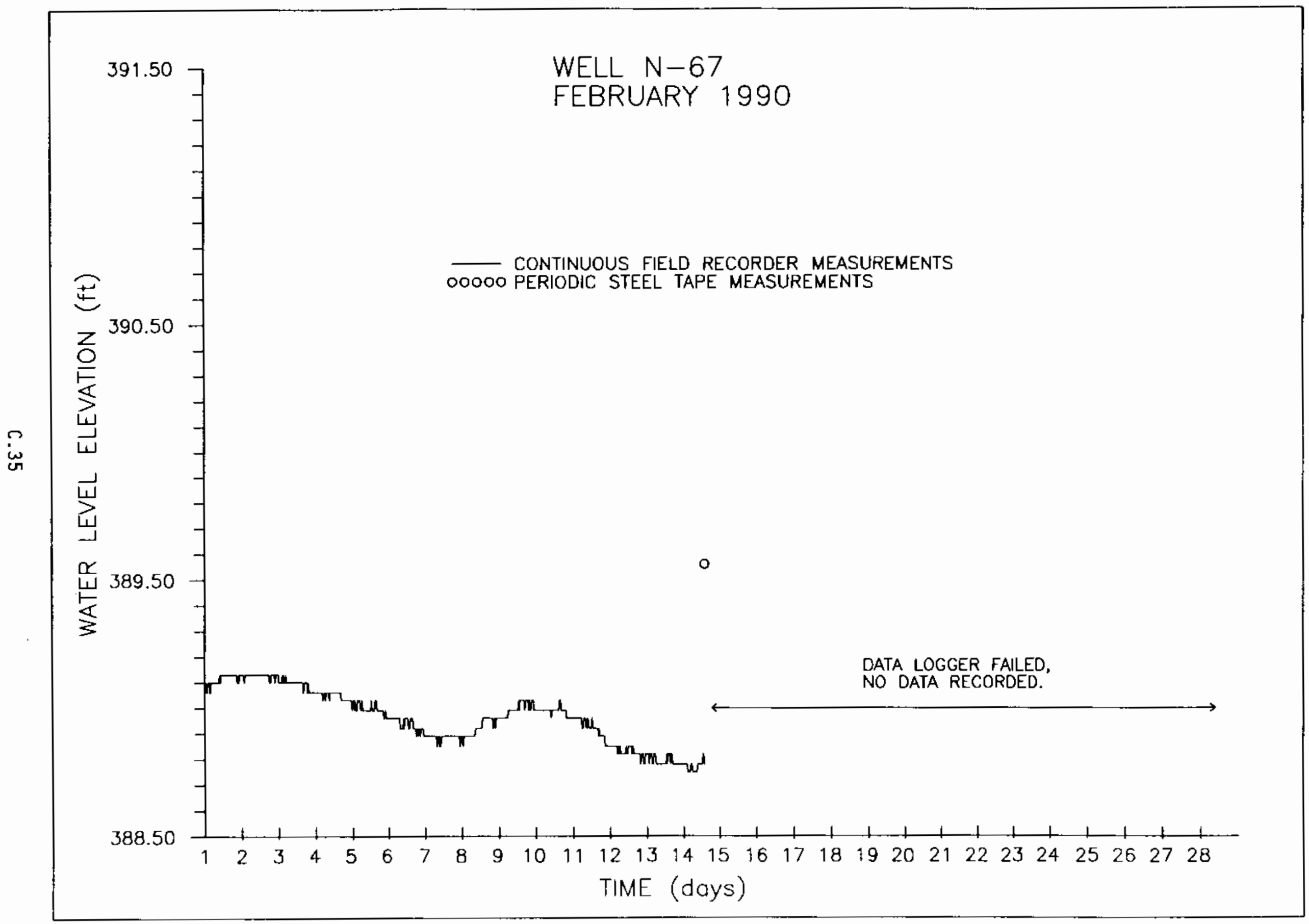




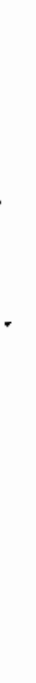




\section{DISTRIBUTION}

No. of

Copies

OFFSITE

2 DOE/Office of Scientific and Technical Information

\section{ONSITE}

1 DOE Richland Operations office

E. C. Norman

6 West inghouse Hanford Company

W. E. Green, Jr.

$M$. J. Hartman

D. J. Watson (4)
No. of

Copies

23 Pacific Northwest Laboratory

J. V. Borghese

R. W. Bryce

J. W. Falco

T. J Gilmore (3)

W. R. Gorst

J. M. Hales

P. C. Hays

E. J. Jensen

G. V. Last

S. P. Luttrell

J. P. McDonald

D. R. Newcomer

W. T. Pennel1

R. L. Skaggs

F. A. Spane

Publishing Coordination

Technical Report Fj]es (5) 
.

-

.

( 